$28^{\text {th }}$ June 2017

Abstract 249 words

Manuscript 5784 words

Tables $=1$

Figures $=3$

Supplementary material: Tables 5, Figures 19

\title{
Epidemiology of psychotic depression - systematic review and meta-analysis
}

E. Jääskeläinen ${ }^{1,2,3 *}$ t, T. Juola ${ }^{1}$, H. Korpela ${ }^{1,2}$, H. Lehtiniemi ${ }^{1}$, M. Nietola ${ }^{4}$, J. Korkeila ${ }^{5}, J$. Miettunen ${ }^{1,2}$

t Equal contribution.

${ }^{1}$ Center for Life Course Health Research, University of Oulu, Finland; ${ }^{2}$ Medical Research Center Oulu, Oulu University Hospital and University of Oulu, Finland; ${ }^{3}$ Department of Psychiatry, Oulu University Hospital, Finland; ${ }^{4}$ Psychiatric Department, University of Turku and Turku University Hospital, Finland; ${ }^{5}$ Psychiatric Department, University of Turku and Satakunta Hospital District, Finland.

${ }^{*}$ Address for the correspondence:

Erika Jääskeläinen

Center for Life Course Health Research

P.O. Box 5000

90014 University of Oulu, Finland

Fax. +358 85315037 , Tel. +358406742959

Email: erika.jaaskelainen@oulu.fi 


\section{Abstract}

Large amount of data have been published on non-psychotic depression, schizophrenia and bipolar disorder, whilst psychotic depression as an own entity has received much smaller attention. We performed a systematic review and meta-analyses on epidemiology, especially incidence and prevalence, risk factors and outcomes of psychotic depression. A systematic search to identify potentially relevant studies was conducted using four electronic databases and a manual search. The search identified 1,764 unique potentially relevant articles, the final study included 99 articles. We found that the lifetime prevalence of psychotic depression varies between $0.35-1 \%$, with higher rates in older age. Onset age of psychotic depression was earlier than that of non-psychotic depression in younger samples, but later in older samples. There were no differences in gender distribution in psychotic depression versus non-psychotic depression, but higher proportion of females was found in psychotic depression than in schizophrenia or in psychotic bipolar disorder. Risk factors have rarely been studied, the main finding being that family history of psychosis and bipolar disorder increases the risk of psychotic depression. Outcomes of psychotic depression were mostly worse when compared to nonpsychotic depression, but better compared to schizophrenia and schizoaffective disorder. The outcome compared to psychotic bipolar disorder was relatively similar, and somewhat varied depending on the measure of the outcome. Based on this review, the amount of research on psychotic depression is far from that of non-psychotic depression, schizophrenia and bipolar disorder. Based on our findings, psychotic depression seems distinguishable from related disorders and needs more scientific attention.

Keywords: psychotic depression, unipolar depression, major depressive disorder, epidemiology, risk, incidence, outcome, prognosis, psychotic disorders, psychosis 


\section{Introduction}

Major depression with psychotic features (hereafter psychotic depression, PD) is a severe disorder with a high risk of recurrence and high mortality in both adult samples under 60 years (Lykouras \& Gournellis, 2009) and older people samples (Gournellis et al. 2014). In spite of the severe course of illness there seems to be some difficulty identifying the disorder in clinical settings (Rothschild et al. 2008).

Originally, Kraepelin (Goodwin et al. 2007) considered PD as a type of manic-depressive illness. In the post-kraepelinian era, it has been classified among unipolar major depressive disorders. In ICD-10 PD is considered the most severe subtype of major depressive disorder (WHO, 1992), whereas in DSM-5 psychotic features are not an indicator of severity of major depression (APA, 2013). Due to a number of differences between PD and non-psychotic depression (hereafter NPD), it has for long been proposed that PD should be considered a distinct disease entity (Schatzberg \& Rothschild, 1992; Keller et al. 2007).

The point prevalence of PD is estimated to be approximately $0.4 \%$, with older adults being in the highest risk (Kivelä \& Pahkala, 1989; Perälä et al. 2007). The prevalence of psychotic features in the adolescent outpatient major depression sample was 18\% (Ryan et al. 1987) while the same figure was $45 \%$ in a hospitalized adolescent patient sample (Haley et al. 1988). There is lack of information concerning the risk factors for PD. Previous studies have often studied all affective psychosis, i.e. included bipolar disorder or studied PD as part of all major depressive disorders. Though there are marked similarities in PD and NPD risk factors, some differences are likely to exist. Also, there is considered a close link between PD and bipolar disorder (Keller et al. 2007; Østergaard et al. 2013). There are no previous systematic reviews on incidence, prevalence, or risk factors of PD. 
Clinical course of illness in PD is more severe than in NPD. This applies especially in the shortterm outcome but it has been suggested that in a longer follow-up the significance of psychotic features might fade (Keller et al. 2007; Lykouras \& Gournellis, 2009). However, mortality is significantly higher in PD compared to NPD (Vythilingam et al. 2003), although there are conflicting findings (Suvisaari et al. 2013). The functional outcome has been suggested to be mostly better in PD compared to schizophrenia (SZ), and differences in outcomes between PD and psychotic bipolar disorder (PBD) have been unclear (Craig et al. 2000; Jarbin et al. 2003; Keller et al. 2007).

Huge amount of data and meta-analyses have been published on NPD, SZ and bipolar disorder, whilst PD as an own entity has received much smaller attention (Crebbin et al. 2008). Meanwhile, there has been a concern over the validity of PD diagnosis mainly due to diagnostic instability (Ruggero et al. 2011). There are some meta-analyses and reviews on pharmacological treatments (Wijkstra et al. 2015), cognition (Fleming et al. 2004; Zaninotto et al. 2015), genetics (Domschke, 2013) neuroimaging studies (Busatto, 2013), cortisol nonsuppression (Nelson \& Davis, 1997) and PD in old age (Gournellis et al. 2014). Lykouras and Gournellis (2009) present a comprehensive review on neurobiology, treatments, epidemiology, course of illness, and outcomes of PD in comparison to NPD. However, they have not reported their results systematically, and some topics such as risk factors have not been studied. Earlier reviews presenting epidemiology of PD (Schatzberg \& Rothschild, 1992; Gournellis \& Lykouras, 2006; Lykouras \& Gournellis, 2009) have not combined the data by meta-analytic means and they have compared their findings only to NPD.

\section{Aims}

Our aim was to perform a systematic review on epidemiology, especially incidence and prevalence, risk factors and outcomes of PD. We also aimed to do a meta-analysis on sex differences, onset age, and outcome of PD in comparison to NPD, SZ, PBD, and schizoaffective disorder (SZAFF). 


\section{Methods}

Data Collection

We applied the PRISMA (Preferred Reporting Items for Systematic reviews and Meta-Analyses) guidelines for systematic reviews and meta-analyses (Moher et al. 2009).

In order to locate potentially suitable studies, we conducted database searches in May 2016 using four electronic databases: PubMed, Scopus, Web of Science, and CINAHL. The used search terms were the following: ("psychotic depression" OR "delusional depression" OR "depression with psychotic features") AND (epidemiology OR "risk factor" OR outcome OR employment OR occupational OR progression OR course OR stability OR relapse OR remission OR prevalence OR incidence OR "onset age" OR "diagnostic stability" OR mortality OR suicide OR physical OR somatic OR comorbidity OR "early intervention" OR prevention). No publication date exclusions were used in the search. Articles were also searched manually from the reference lists of the previous reviews.

All abstracts were independently analysed by two authors (HK and EJ). After the exclusion of irrelevant abstracts, all remaining articles were critically inspected by two authors (EJ or JM). For studies that met inclusion criteria, a third investigator (HL or TJ) independently extracted the data, and the collected data were checked by two authors (JM or EJ). When a disagreement occurred related to data extraction, this was resolved by consensus.

\section{Study selection}

Studies on prevalence and incidence were included if these were estimated from population surveys or used both inpatient and outpatient data to estimate prevalence or incidence. 
Regarding studies on risk factors and outcomes in PD, to be included in the analyses, the studies had to be characterized by all of the following:

1. Original study included a sample of PD. Also studies including only delusional depression were included, as the early studies on the topic often used only this definition. The sample had to include at least $80 \%$ of PD. Studies focusing on psychotic depressive episode of SZ or PBD, or studies with postpartum psychotic depression were not included.

2. Diagnostic assessment and diagnostic criteria of PD was based on a commonly used diagnostic system or was otherwise adequately reported.

3. The sample size of PD was at least 15.

4. Studies presented risk or sociodemographic factors, or outcomes of PD.

5. Studies of risk factors and outcomes had to include a comparison group of NPD, PBD, SZ, SZAFF, or healthy controls without mental disorder. The size of the comparison group had to be at least 15 and the comparison group had to include at least $80 \%$ of NPD, PBD, SZ, or SZAFF.

6. The majority of subjects had onset age after 16 years.

Only observational (naturalistic) studies were included, whereas trials and intervention studies were excluded. While many intervention studies report clinical outcomes, the representativeness of these samples may vary widely according to the specific trial inclusion criteria. Thus, a large number of randomized controlled trials were excluded. To the current review, we finally included only studies published in English. In addition, studies analyzing neurobiological risk factors and correlates, treatments, mortality, suicides, and somatic comorbidities were excluded as being either out of the scope of this review (studies on treatments, neurobiology, somatic comorbidities) or being recently studied (mortality and suicides in PD; Lykouras \& Gournellis, 2009; Rothschild, 2009; Zalpuri \& Rothschild 2016).

Incidence, prevalence and risk factor studies 
Studies on incidence and prevalence were reported with a systematic review. Regarding gender distribution and onset age we pooled studies using meta-analytic methods. Other risk factors were reported only narratively and in a literature table. The included risk factors encompassed both early risk factors and sociodemographic factors, such as marital status and education, collected at study entry.

\section{Outcome studies}

Of studies analyzing outcomes of PD, studies analyzing the severity of psychotic symptoms (positive, negative, total symptoms), severity of depression symptoms, number of hospitalizations during prospective follow-up, symptomatic remission, global clinical outcome, global outcome and occupational functioning were included. Global clinical outcome indicates outcome measured by the presence of clinical symptoms and severity of illness, without a specific instrument for the measurement. Global outcome indicates the outcome measured by Social and Occupational Functioning Assessment Scale (SOFAS), Global Assessment Scale (GAS) or Global Assessment of Functioning scale (GAF). Please see our earlier meta-analyses for the definitions of different outcome dimensions (Käkelä et al. 2014; Penttilä et al. 2014). Based on the number of studies (at least 3 studies from different samples per outcome), meta-analysis was performed on depression symptoms, total psychotic symptoms, positive and negative symptoms, global outcome, symptomatic remission and poor global clinical outcome. For the meta-analysis, we selected symptoms measured at the baseline of studies, since this was the most common time of assessment of symptoms. In meta-analysis, outcomes where compared between PD and NPD, SZ, and PBD when data was available. Systematic review (without meta-analysis) was done for hospitalizations and occupational functioning.

Statistical analyses

Random effects models were used in order to pool estimates of effect sizes between PD and 
comparison groups in the meta-analyses of gender, onset age, symptoms, symptomatic remission, global clinical outcome, and hospitalizations, based on the expected heterogeneity of the associations. Meta-analyses were done if at least three studies investigated same outcome. In the random-effects analysis, each study was weighted by the inverse of its variance and the betweenstudies variance. In continuous variables (onset age and symptoms), the effect size of the standardised mean difference between groups was described with Hedges' g. Hedges' g values is comparable with Cohen's d but recommended with small sample sizes. It can be interpreted as small 0.20 , moderate 0.50 and large 0.80 effect (Cohen, 1992). In categorical variables, pooled effect size was estimated using Relative Risk (RR) with 95\% confidence interval $(\mathrm{Cl})$. When the number of studies allowed, we checked the results of meta-analyses in the subgroups of studies based on publication year (1973-1991, 1993-2003, and 2004-2016), mean study age (below 45, 45 to 55 , and above 55 years), or mean age of illness onset (below 45 versus 45 or above). In addition, as a sensitivity analyses, we performed analyses in strata by sample size (studies under 50 cases vs. at least 50 cases with PD). In the current study, positive $g$ values indicate that individuals with PD have more symptoms or later onset age than comparison group. Where multiple articles were available on the same or overlapping samples and presenting similar data, we selected one representative paper with the largest sample size or presenting outcomes measured by a more commonly used instrument for the meta-analysis. We assessed the heterogeneity of the studies using $\mathrm{I}^{2}$ statistics, and the statistical significance in heterogeneity was tested using the chi-square test. Values of $\mathrm{I}^{2}$ range from $0 \%$ to $100 \%$, reflecting the proportion of total variation across studies beyond chance. A value of $25 \%$ describes low, $50 \%$ moderate, and $75 \%$ high heterogeneity (Higgins et al. 2003). An alpha level of 0.05 was used for all statistical tests. The metan command of the Stata version 13 (StataCorp 2013; Sterne 2009) was used in all analyses.

\section{Results}


Database searches identified 2,926 records, which reduced to 1,764 after the removal of duplicates. After analysing the abstracts, we were left with 279 articles that potentially fulfilled our inclusion criteria. The most common reason for exclusion during abstract screening was that the article did not present results separately to PD. Figure 1 shows the flow diagram that details the exclusion criteria after abstract reading. In total, 99 studies met all of our criteria regarding incidence/prevalence, risk factors or outcome, and were included in the systematic review. The studies included nine studies from manual search.

Insert Figure 1 here.

Incidence and prevalence

Studies reporting prevalence or incidence estimates in community samples and using estimates based on inpatient and outpatient data have been collected into the Supplement Table 1.

Only four studies estimated prevalence in community samples, trying also to detect cases not in treatment using different screening methods. In the nationally representative Finnish Health 2000 sample, Perälä et al. (2007) found a lifetime prevalence of $0.35 \%$ for DSM-IV PD. The prevalence was higher among those who were 65 years or more $(0.43 \%)$ when compared with younger age groups, however differences were not statistically significant. In the US Epidemiological Catchment Area (ECA) study, Johnson et al. (1991) reported a lifetime prevalence of DSM-III PD to be $0.6 \%$. In an older community based study of those with 60 years or more, the prevalence was $1.0 \%$ $(0.6 \%$ for males, $1.2 \%$ for females) (Kivelä \& Pahkala, 1989). In a large European telephone survey in five countries, an overall point prevalence for DSM-IV PD was $0.5 \%$, and significantly higher rates were reported for females $(0.6 \%)$ than males $(0.3 \%)$ (Ohayon \& Schatzberg, 2002).

Five studies used different in- and outpatient admission registers. Estimates for annual incidence 
(per 100,000 persons) were reported in three studies. In a British study, Farquhar et al. (2007) reported an incidence of 3.4 in the year 1875-1924 and 3.0 in 1995-1999. In an Irish study, Baldwin et al. (2005) found an incidence of 6.4 (males 5.4 and females 7.4), similar estimates (6.0 for those with 16 years and over) were also in a British study by Reay et al. (2010). A Finnish study comparing two birth cohorts (from 1966 and 1986), found a substantial increase in cumulative incidence until age 27 years in the later cohort (0.02\% vs. 0.21\%) (Filatova et al. 2016).

Gender differences have been reported in some incidence and prevalence studies. In three studies, females had higher estimates for incidence (Kivelä \& Pahkala, 1989; Ohayon \& Schatzberg, 2002; Baldwin et al. 2005), however in one study higher lifetime prevalence was reported for males (0.41\%) than females (0.29\%) (Perälä et al. 2007).

Proportion of psychosis in depression

In studies $(n=43)$ including both PD and NPD patients, the median proportion of PD patients was $28 \%$ of all depressive patients. Median proportion was lower in studies with mean age below 45 years $(20 \%, n=16)$ than in the middle age samples $(27 \%, n=11)$ or in older samples $(34 \%, n=10)$. The median proportion of PD in depression patients was $29 \%$ among females and $26 \%$ among males. In the studies including only depressive inpatients $(n=22)$, the median proportion of those with PD was $42 \%$ whereas in the studies including both in- and outpatients or only outpatients ( $n=21)$, corresponding proportion was $19 \%$.

\section{Gender differences in PD when compared with other patient samples}

We compared gender distributions in the included studies on PD and patient control groups. In total 57 studies compared PD with other included patients samples. The median number of PD patients was 45 in these studies, whereas the total number of PD patients was 28,370 . In total 43 studies compared gender distributions between PD and NPD, pooled RR being 1.03 (95\% Cl 
0.97-1.08). Estimates of RR were relatively similar when studies were divided by mean study age or year of publication. The estimated RRs for PD for females are presented in Figure 2, for the total sample and by mean study age. Studies comparing PD and SZ and PBD found a higher proportion of females in PD than in SZ (14 studies; RR 1.40, 95\% Cl 1.20-1.71) or in PBD (3 studies; RR $1.36,95 \% \mathrm{Cl} 1.01-1.83)$. The median percentage of females in PD was $65 \%$, in NPD $65 \%$, in SZ $37 \%$, in SZAFF 57\%, and in PBD 55\%. Proportion of females in PD did not vary significantly when studies were divided by mean study age or year of publication. Proportions of females in different patient groups in the included studies are presented in the Supplement Table 2.

Insert Figure 2 here.

Onset age in PD when compared with other patient samples

Eighteen studies compared onset age between PD and NPD in different samples. Based on metaanalysis there was no significant difference between the groups (Hedges' $g=0.08, p=0.44$ ). However, when we divided the studies into three categories based on mean study age, we found conflicting results. In the studies of the youngest subjects (below 45 years, $n=6$ ), PD patients had earlier onset age $(g=-0.39, p<0.001)$, whereas in the studies among the oldest (above 55 years, $\mathrm{n}=7)$ PD patients had later onset age $(\mathrm{g}=0.40, \mathrm{p}<0.001)$ than NPD patients. The year of publication did not affect the results. A forest plot comparing onset age between PD and NPD by age groups and in the total sample is presented in Figure 3. In the six studies comparing mean onset age between PD and SZ, five found earlier onset age in SZ, and pooled meta-analysis found significant difference $(g=0.53, p=0.013)$. When we compared PD and PBD, PD patients had non-significantly later onset age $(g=0.34, p=0.069)$. Mean onset ages in different groups in the included studies are presented in the Supplement Table 3.

Insert Figure 3 here. 
Regarding comparison in onset age between PD and NPD, only six studies had sample size of at least 50 . There were only two studies from each three age groups, however all the statistical significant findings remained when compared to the original analyses.

\section{Risk factors and sociodemographic factors}

Studies on risk factors and sociodemographic factors in PD are summarized in the Supplement Table 4. In total 36 studies were found.

Studies on early risk factors are rare. The only study analyzing risk factors from birth (place of birth, gestational age, birth weight, small for gestational age, maternal and paternal age at birth) was a large Danish register study that did not find any significant differences in these factors between PD and healthy controls (HC) (Østergaard et al. 2013). Physical and sexual trauma was more likely in PD than in NPD in one study (84\% vs. 64\%, p=0.017) (Gaudiano \& Zimmerman, 2010), but not in one (Gaudiano et al. 2016). Other premorbid factors linked with PD when compared with NPD were rural domicile (Ihezue, 1985), acute medical problems (Draper \& Anstey, 1996), and poorer social competence score (Sands \& Harrow, 1995). When compared with HC, PD patients differed in number of physical anomalies (Čulav-Sumić \& Jukić, 2010) and also a loss of mother because of an unnatural cause after age 15 years associated with PD (Østergaard et al. 2013). Ethnicity was studies in eight articles. Individuals with PD were less likely to be Caucasian in five different studies (Johnson et al. 1991; Goldberg \& Harrow, 2005; Gaudiano et al. 2009; Gaudiano \& Zimmerman, 2010; Gaudiano et al. 2016). The British study by Heslin et al. (2016a) found that PD patients had less contact with friends, and they were more likely to have childhood adversity of neurological soft signs when compared with HC.

The family history of different psychiatric illnesses and suicides was analyzed in 14 articles. Most of the associations were non-significant. When PD patients were compared with NPD, they more often had a family history of psychosis (Buoli et al. 2013) and bipolar I disorder (Maj et al. 2007). 
One study also found a higher likelihood of any mental illness in relatives (Okulate et al. 2001), whereas two other studies did not find differences (Frangos et al. 1983; Nakamura et al. 2015). Studies looking at the family history of affective or depressive disorders did not find differences between PD and NPD (Frangos et al. 1983; Parker et al. 1991; Simpson et al. 1999; Park et al. 2014). The large Danish register study by Østergaard et al. (2013) found several maternal, paternal and sibling psychiatric diagnoses to associate significantly with PD when compared with $\mathrm{HC}$, the highest risk (Incidence Rate Ratio of 2.2) being in any maternal mental disorder. Also a recent study in the UK found the family history of any mental illness or psychosis to associate with PD (Heslin et al. 2016a).

Educational level or years of education between PD and other patient groups was compared in 18 studies. Differences were mainly non-significant. PD patients had less education when compared with PBD in one study (Breslau \& Meltzer, 1988). When PD patients were compared with NPD, they had lower education in six studies (Ihezue, 1985; Karaaslan et al. 2003; Goldberg \& Harrow, 2005; Gaudiano et al. 2009; Gaudiano \& Zimmerman, 2010; Heslin et al. 2016b) but more years of education in one study (Park et al. 2014). In the ECA study PD patients had lower socioeconomic status when compared with NPD (Johnson et al. 1991). Marital status between PD and other patient groups was compared in 19 studies. Differences were mainly non-significant although two studies found PD patients to be more often single than NPD patients (Baldwin, 1995; Gaudiano et al. 2016) and in one study PD patients were less often single when compared to SZ patients (Heslin et al. 2016b).

\section{Outcomes in psychotic depression}

Study characteristic and quality. The studies included in outcome review are described in Supplement Table 5. We found altogether 44 articles presenting results from 37 separate studies. Several studies did not report characteristics of PD group in detail (Supplement Table 5). The sample sizes of PD varied between 16 and 190. 14 of the studies had sample size at least 50 . In 
25 of the studies there were more females than males. 25 studies included patients with onset age before 45 years of age (or if age of onset not reported, the sample was under 45 years at the study moment). Most of the studies ( $n=16)$ were cross-sectional, and 13 studies had over 5 years followup. Study populations were mostly mixed samples $(n=25)$, with minority being first-episode $(n=10)$ and consecutive samples $(n=2)$. Outcomes were most frequently defined using validated scales, but in some studies the scale or its use were not clearly reported. Most commonly studied outcomes were different symptoms, remission, and global clinical outcome.

Outcome compared to NPD. Based on meta-analysis (Supplement Figures 1a-f), compared to NPD, the symptoms of depression were more severe in PD (Hedges' $g=0.52, p<0.001$ ). The difference in symptom severity was larger among three samples with onset age 45 years or older ( $g=0.84, p=0.004)$, but significant also in younger samples $(g=0.40, p=0.005)$. Psychosis symptoms were more severe in PD $(g=0.89, p=0.037)$. Symptomatic remission tended to be less common in PD though not statistically significantly $(R R=0.82, p=0.052)$. There was no significant difference in the global clinical outcome or hospitalizations, though PD patients tended to have poorer outcomes. The global outcome (based on SOFAS, GAS, or GAF score) was somewhat worse in PD, but not statistically significantly $(g=-0.43, p=0.065)$. Sensitivity analyses by sample size were performed for studies comparing depression symptoms, global outcome, symptomatic remission and poor global clinical outcome in PD versus NPD. The results were mixed. Regarding depression symptoms the difference in PD vs. NPD was not statistically significant in larger samples (50 cases or more), and the results of global outcome remained non-significant. Regarding symptomatic remission and poor clinical outcome, the difference between PD and NPD was statistically significant in large samples (Supplement Figures 4a-d).

Based on systematic review (Supplement Table 5), the rate of relapses was higher in PD compared to NPD (Baldwin 1988, Copeland 1983). In most of the studies analyzing occupational outcomes, individuals with PD had a somewhat poorer outcome compared to NPD (Coryell et al. 1984; Coryell \& Tsuang, 1985). However, there were also studies indicating similar occupational 
outcomes for PD and NPD (Jäger et al. 2005; Rush et al. 2006; Park et al. 2014). A good occupational outcome occurred in $60-79 \%$ of PD, and 68-78\% on NPD (Coryell \& Tsuang, 1985; Jäger et al. 2005; Park et al. 2014), and poor occupational outcome in $28 \%$ of PD and 19\% of NPD (Coryell \& Tsuang, 1985), and unemployment in 90\% of PD and $81 \%$ of NPD (Rush et al. 2006). Based on only study analyzing full recovery (both symptomatic and functioning, Coryell et al. 1982), full recovery after 2-3 years of follow-up was more common in NPD (69\%) than PD (40\%).

Outcome compared to SZ. According to meta-analyses, when compared to SZ, there was no difference in severity of depression symptoms, but total psychosis symptoms $(g=-0.77, p=0.000)$ and positive $(g=-0.81, p=0.000)$ and negative symptoms $(g=-0.89, p<0.001)$ were significantly less severe in PD. Global outcome was better in PD $(g=0.80, p=0.001)$ (Supplement Figures 2a-e). All but one of the samples in the meta-analyses included patients with mean onset age below 40 years. The rate of relapses was lower in PD (Craig et al. 2000). Occupational functioning was better in PD, $60-79 \%$ of PD and $36-47 \%$ of SZ having a good occupational outcome, and $28-29 \%$ and 57-88\% having poor, respectively (Coryell \& Tsuang, 1985; Jarbin et al. 2003; Jäger et al. 2005). Full recovery (both symptomatic and functioning, Coryell et al. 1982) after 2-3 years of follow-up was more common in PD (40\%) than SZ (7\%) (Supplement Table 5).

Outcome compared to PBD. Symptoms of depression did not differ. Negative symptoms ( $\mathrm{g}=0.65$; $p=0.001)$ were more severe in PD. However, PD had less severe positive symptoms $(g=-0.44$; $p=0.046$ ). There was no difference in global functioning between PD and PBD (Supplement Figures 3a-d). Rehospitalization rates were relatively similar in PD and PBD (Craig et al. 2000). The unemployment rate was similar in PD and PBD (63 vs. 53-69\%) (Dell'Osso et al. 2002), as was functional recovery (32 vs. 37\%, Tohen et al. 2000). Persons with PD were somewhat less often on a disability pension ( $29 \%$ vs. $33 \%)$, and they were less often unemployed ( $7 \%$ vs. $14 \%)$ (Supplement Table 5).

Outcome compared to SZAFF. Only a few studies comparing PD and SZAFF were found, and no 
meta-analysis could be performed. Symptomatic remission (Coryell et al. 1990, Opjordsmoen et al. 1991), and employment (Opjordsmoen et al. 1991) were more common in PD, but there was no difference in number of relapses at follow-up (Opjordsmoen et al. 1991). In one study, there was no marked difference in syndromatic recovery between PD and SZAFF, but PD subjects had more often functional recovery (Tohen et al. 2000).

\section{Discussion}

\section{Main results}

Based on this systematic review, though not as common as for example schizophrenia, it seems that PD is relatively common, especially in older populations. However, this conclusion is based on a relatively few studies with varying methodology. Within depression, the onset age of PD was earlier than that of NPD in younger samples, but later in older samples. This may be due to PD at first episode being a marker of later bipolar disorder in younger samples. It seems that the proportion of PD is higher in inpatient samples. Based on this review, the median proportion of those with PD was $42 \%$ in inpatients, and $19 \%$ in outpatients. There was no difference in gender distribution in PD versus NPD, but higher proportion of females was found in PD than in SZ or in PBD. Risk factors have rarely been studied, and most of the findings were statistically nonsignificant. Family history of psychosis and bipolar I seems to increase the risk of PD.

To our knowledge, this is a first systematic review and meta-analysis comparing the outcomes of PD not only to NPD, but to also to SZ, SZAFF and PBD. Several outcomes of PD were mostly worse when compared to NPD, but better compared to SZ and SZAFF. The outcomes compared to PBD were relatively similar, though there were more negative and less positive symptoms in PD. The number of studies comparing PD to SZ and PBD, and especially SZAFF are very few.

Please see Table 1 for the summary of main results. 


\section{Clinical and public health implications}

The number of studies on the epidemiology of PD are far from the large amount of studies on SZ (e.g. Matheson et al. (2014) or on unipolar depression in general (e.g. Kessler \& Bromet, 2013; Hirschfeld, 2012) and on bipolar disorder (Benazzi, 2007; Esan \& Esan, 2016; Sherazi et al. 2006). Many of the risk factors reviewed in reviews on NPD and SZ have not been studied on PD at all or only in a few small samples. Based on our review, there is lack of studies on epidemiology, especially risk factors, and longitudinal clinical and functional outcomes in PD. This is in line with the general notion of lack of clinical trials focusing on PD (Wijkstra et al. 2015). In addition, both treatment algorithms and clinical practice regarding PD are highly heterogeneous. This emphasizes the need for further studies also on the treatment of PD (Leadholm et al. 2013).

Our review supports the earlier conclusions about more severe depression symptoms in PD compared to NPD especially in older samples (Lykouras \& Gournellis, 2009). Most of the studies included in the meta-analysis included patients with relatively young age at the study moment, and thus the other results on symptoms and global outcome can be generalized only to this age group.

Our review summarizes the outcomes of PD in comparison to SZ and PBD. After our database searches, very recently, an AESOP study was published, where 10-year outcomes in PD compared to SZ and PBD patients were investigated. The study found only minimal differences in the outcome between PD and PBD. Differences in clinical, social and service use outcomes between PD and SZ were more substantial with PD patients showing better outcomes on most variables. (Heslin et al. 2016a). These results of AESOP seems relatively similar to ours.

The burden of disease of mood disorders to society among EU nations is higher than in any other brain disorders, most of the costs resulting from disability (Olesen et al. 2012). There are not many studies on the disability due to PD. In PD, disability was found to be increased even when 
compared to severe major depression in all functional dimensions of Short Form-36, there were, moreover, an increased number of absent days and days ill in bed (Kruijshaar et al. 2003). Severe forms of recurrent depressions, additionally, may have a scar effect in the form of an increase in disability (Ormel et al. 2004). Due to earlier age of onset and higher prevalence, the burden of disease on society is likely to be higher in SZ, although self-perceived suffering may be worse due to depression being a robust determinant of quality of life (Saarni et al. 2010).

Diagnostic instability has been a concern with PD (Bromet et al. 2011; Ruggero et al. 2011). In tenyear follow-up studies of relatively young patient samples the diagnosis of PD has remained in less than half of the cases (Bromet et al. 2011; Ruggero, 2011; Heslin et al. 2015) and Ruggero et al. (2011) have even suggested that PD diagnosis should be considered as a provisional diagnosis. However, in a two-year follow-up of slightly more aged sample the stability was $85 \%$ (Salvatore, 2011). The early onset of PD may well predict conversion to bipolar disorder (Østergaard et al. 2014). Additionally, changes in the symptom presentation seem to explain the instability (Bromet et al. 2011). A shift towards SZ has also been found during the course of a decade. Among these cases, poorer functioning and negative symptoms predicted the shift (Bromet et al. 2011). Altogether the stability of diagnosis in PD can be highly age-related as especially younger patients are more likely to develop PBD (Lykouras \& Gournellis, 2009). The diagnosis might also be more stable in patients with medical co-morbidity (Tohen et al. 2012). Still, among mood disorders bipolar disorder has been found to best predict psychosis (Souery et al. 2011).

Considering the diagnostic validity of PD it is interesting that gender distribution in PD is similar to NPD while the proportion of females is lower in SZ and PBD. Meanwhile, the differences between PD and NPD are well documented (Keller et al. 2007) and our findings are in line with these. Also, the increasing prevalence, though not statistically significant, and proportion of psychosis in depression in older patient samples contradicts with the concept of psychotic illness, for example SZ, starting usually at early adulthood. In this systematic review onset age of PD was earlier than 
that of NPD in younger samples, but later in older samples. It remains possible that there are two forms of PD. PD in young adulthood may be an etiologically and prognostically different illness than PD in late adulthood and in geriatric populations. Early onset form of PD may be more unstable, potentially an early expression for some patients of bipolar disorder, and for others perhaps other psychotic conditions. Among older onset cases it is possible that medical and neurological conditions partly explain the occurrence of PD. Future studies should address these questions and include also late-onset PD patients.

\section{Strengths and limitations}

There are several limitations related to this review. We included only articles published in English, meaning that especially older relevant articles on the topic may be missing. It should be acknowledged, that the oldest studies in this review were from 1980s. Although we consider our search criteria to be adequate, we may have missed some studies, especially older studies. Because of this we, have also done some manual work to locate these papers, e.g. using the

reference lists of previous reviews. It should be noted that we excluded childhood onset samples. The included articles were quite mixed regarding methods, e.g. diagnostic criteria or other inclusion criteria. The original studies on incidence and prevalence rates were few, and they had very heterogeneus methodology. There were four population studies with different design and methods of ascertaining the PD cases, and five registry studies. These two sets of studies produced considerably different estimates of PD. It may be that the available data are too heterogeneous to make precise estimate if incidence and prevalence of PD.

The sample sizes were relatively small, e.g. in risk factors median sample size being 45, and mainly not based on population samples, but comparing clinical samples. Minority of the studies based on first-episode samples. Most of the studies on outcomes had sample size of PD under 50. Due to the low number of studies it is not possible have a clear picture on the effect of study quality (e.g. sample size) on the results. However, based on the study characteristic summarized in 
Results, many of the original studies have important limitations (e.g. small sample size, short follow-ups, lack of long-term follow-ups in older populations). In outcome analyses, some of the definitions of outcomes were heterogeneous, e.g. definitions of symptomatic remission, global clinical outcome, global outcome varied.

The strength of this review was the comprehensive search strategy, as we searched four electronic databases. We read in detail studies analyzing depression in general, and whenever possible, extracted the data concerning PD as separate group. There was a relatively good amount of data on gender differences, differences in onset age, and differences in some of the outcome measures to also allow new conclusions on the epidemiology of PD.

\section{Conclusions}

To our knowledge, this is the first systematic review on different aspects of epidemiology of PD. Based on this review, the amount of research on PD is far from that of NPD, SZ and bipolar disorder. Based on differences in gender, onset age and outcomes in PD in comparison to other disorders, PD seems distinguishable from related disorders and needs more scientific attention.

\section{Acknowledgements}

This work was supported by grants from the NARSAD: Brain and Behavior Research Fund and the Academy of Finland (\#268 336, \#278 286). The funders had no role in the manuscript.

\section{Declaration of Interest}

None. 


\section{References}

American Psychiatric Association (APA) (2013). Diagnostic and statistical manual of mental disorders, 5th edition: DSM-5. American Psychiatric Publishing: Arlington, VA.

Baldwin RC (1995). Delusional depression in elderly patients: characteristics and relationship to age at onset. International Journal of Geriatric Psychiatry 10, 981-985.

Baldwin RC (1988). Delusional and non-delusional depression in late life. Evidence for distinct subtypes. British Journal of Psychiatry 152, 39-44.

Baldwin P, Browne D, Scully PJ, Quinn JF, Morgan MG, Kinsella A, Owens JM, Russell V, O'Callaghan E, Waddington JL (2005). Epidemiology of first-episode psychosis: illustrating the challenges across diagnostic boundaries through the Cavan-Monaghan study at 8 years. Schizophrenia Bulletin 31, 624-638.

Benazzi F (2007). Bipolar II disorder: epidemiology, diagnosis and management. CNS Drugs 21, 727-740.

Breslau N, Meltzer HY (1988). Validity of subtyping psychotic depression: examination of phenomenology and demographic characteristics. The American Journal of Psychiatry 145, 35-40.

Bromet EJ, Kotov R, Fochtmann LJ, Carlson GA, Tanenberg-Karant M, Ruggero C, Chang SW (2011). Diagnostic shifts during the decade following first admission for psychosis. The American Journal of Psychiatry 168, 1186-1194.

Buoli M, Caldiroli A, Altamura AC (2013). Psychotic versus non-psychotic major depressive disorder: a comparative naturalistic study. Asian Journal of Psychiatry 6, 333-337.

Busatto GF (2013). Structural and functional neuroimaging studies in major depressive disorder with psychotic features: a critical review. Schizophrenia Bulletin 39, 776-786.

Cohen J (1992). A power primer. Psychological Bulletin 112, 155-159.

Copeland JR (1983). Psychotic and neurotic depression: discriminant function analysis and fiveyear outcome. Psychological Medicine 13, 373-383.

Coryell W, Keller M, Lavori P, Endicott J (1990). Affective syndromes, psychotic features, and prognosis. I. Depression. Archives of General Psychiatry 47, 651-657.

Coryell W, Lavori P, Endicott J, Keller M, VanEerdewegh M (1984). Outcome in schizoaffective, psychotic, and nonpsychotic depression. Course during a six- to 24-month follow-up. Archives of General Psychiatry 41, 787-791.

Coryell W, Tsuang MT (1985). Major depression with mood-congruent or mood-incongruent psychotic features: outcome after 40 years. The American Journal of Psychiatry 142, 479-482.

Coryell W, Tsuang MT, McDaniel J (1982). Psychotic features in major depression. Is mood congruence important? Journal of Affective Disorders 4, 227-236.

Craig TJ, Bromet EJ, Fennig S, Tanenberg-Karant M, Lavelle J \& Galambos N (2000). Is there an association between duration of untreated psychosis and 24-month clinical outcome in a first-admission series? American Journal of Psychiatry 157, 60-66.

Crebbin K, Mitford E, Paxton R, Turkington D (2008). Firstepisode psychosis: an epidemiological survey comparing psychotic depression with schizophrenia. Journal of Affective Disorders 105, 117-124. 
Čulav-Sumić J, Jukić V (2010). Minor physical anomalies in women with recurrent unipolar depression. Psychiatry Research 176, 22-25.

Dell'Osso L, Pini S, Cassano GB, Mastrocinque C, Seckinger RA, Saettoni M, Papasogli A, Yale SA, Amador XF (2002). Insight into illness in patients with mania, mixed mania, bipolar depression and major depression with psychotic features. Bipolar Disorders 4, 315-322.

Domschke K (2013). Clinical and molecular genetics of psychotic depression. Schizophrenia Bulletin 39, 766-775.

Draper B, Anstey K (1996). Psychosocial stressors, physical illness and the spectrum of depression in elderly inpatients. The Australian and New Zealand Journal of Psychiatry $\mathbf{3 0}$, 567-572.

Esan O, Esan A (2016). Epidemiology and burden of bipolar disorder in Africa: a systematic review of data from Africa. Social Psychiatry and Psychiatric Epidemiology 51, 93-100.

Farquhar F, Le Noury J, Tschinkel S, Harris M, Kurien R, Healy D (2007). The incidence and prevalence of manic-melancholic syndromes in North West Wales: 1875-2005. Acta Psychiatrica Scandinavica. Supplementum (433), 37-43.

Filatova S, Marttila R, Koivumaa-Honkanen H, Nordström T, Veijola J, Mäki P, Khandaker GM, Isohanni M, Jääskeläinen E, Moilanen K, Miettunen J (2016). A comparison of the cumulative incidence and early risk factors for psychotic disorder in young adults in the Northern Finland Birth Cohorts 1966 and 1986. Epidemiology and Psychiatric Sciences [Epub ahead of print].

Fleming SK, Blasey C, Schatzberg AF (2004). Neuropsychological correlates of psychotic features in major depressive disorders: a review and meta-analysis. Journal of Psychiatric Research 38, 27-35.

Frangos E, Athanassenas G, Tsitourides S, Psilolignos P, Katsanou N (1983). Psychotic depressive disorder. A separate entity? Journal of Affective Disorders 5, 259-265.

Gaudiano BA, Dalrymple KL, Zimmerman M (2009). Prevalence and clinical characteristics of psychotic versus nonpsychotic major depression in a general psychiatric outpatient clinic. Depression and Anxiety 26, 54-64.

Gaudiano BA, Weinstock LM, Epstein-Lubow G, Uebelacker LA, Miller IW (2016). Clinical characteristics and medication use patterns among hospitalized patients admitted with psychotic vs nonpsychotic major depressive disorder. Annals of Clinical Psychiatry 28, 5663.

Gaudiano BA, Zimmerman M (2010). The relationship between childhood trauma history and the psychotic subtype of major depression. Acta Psychiatrica Scandinavica 121, 462-470.

Goldberg JF, Harrow M (2005). Subjective life satisfaction and objective functional outcome in bipolar and unipolar mood disorders: a longitudinal analysis. Journal of Affective Disorders 89, 79-89.

Goodwin FK, Jamison KR (2007). Manic-Depressive Illness: Bipolar Disorders and Recurrent Depression. Oxford University Press: New York.

Gournellis R, Lykouras L (2006). Psychotic (delusional) major depression in the elderly: a review. Current Psychiatry Reviews 2, 235-244. 
Gournellis R, Oulis P, Howard R (2014). Psychotic major depression in older people: a systematic review. Internatinal Journal of Geriatric Psychiatry 29, 789-796.

Haley GM, Fine S, Marriage K (1988). Psychotic features in adolescents with major depression. Journal of the American Academy of Child \& Adolescent Psychiatry 27, 489-493.

Heslin M, Desai R, Lappin JM, Donoghue K, Lomas B, Reininghaus U, Onyejiaka A, Croudace T, Jones PB, Murray RM, Fearon P, Doody GA, Dazzan P, Fisher HL, Demjaha A, Craig T, Morgan C (2016a). Biological and psychosocial risk factors for psychotic major depression. Social Psychiatry and Psychiatric Epidemiology 51, 233-245.

Heslin M, Lappin JM, Donoghue K, Lomas B, Reininghaus U, Onyejiaka A, Croudace T, Jones PB, Murray RM, Fearon P, Doody GA, Dazzan P, Craig TJ, Morgan C (2016b). Ten-year outcomes in first episode psychotic major depression patients compared with schizophrenia and bipolar patients. Schizophrenia Research 176, 417-422.

Heslin M, Lomas B, Lappin JM, Donoghue K, Reininghaus U, Onyejiaka A, Croudace T, Jones PB, Murray RM, Fearon P, Dazzan P, Morgan C, Doody GA (2015). Diagnostic change 10 years after a first episode of psychosis. Psychological Medicine 45, 2757-2769.

Higgins JP, Thompson SG, Deeks JJ, Altman DG (2003). Measuring inconsistency in metaanalyses. British Medical Journal 327, 557-560.

Hirschfeld RM (2012). The epidemiology of depression and the evolution of treatment. Journal of Clinical Psychiatry 73, Suppl 1, 5-9.

Ihezue UH (1985). Observations and comments on the psychosocial determinants of depressive illness among Nigerian adults. Journal of the National Medical Association 77, 729-733.

Jäger M, Bottlender R, Strauss A, Möller HJ (2005). Fifteen-year follow-up of Diagnostic and Statistical Manual of Mental Disorders, Fourth Edition depressive disorders: the prognostic significance of psychotic features. Comprehensive Psychiatry 46, 322-327.

Jarbin H, Ott Y, Von Knorring AL (2003). Adult outcome of social function in adolescent-onset schizophrenia and affective psychosis. Journal of the American Academy of Child and Adolescent Psychiatry 42, 176-183.

Johnson J, Horwath E \& Weissman MM (1991). The validity of major depression with psychotic features based on a community study. Archives of General Psychiatry 48,1075-1081.

Käkelä J, Panula J, Oinas E, Hirvonen N, Jääskeläinen E, Miettunen J (2014). Family history of psychosis and social, occupational and global outcome in schizophrenia: a meta-analysis. Acta Psychiatrica Scandinavica 130, 269-278.

Karaaslan F, Gonul AS, Oguz A, Erdinc E, Esel E (2003). P300 changes in major depressive disorders with and without psychotic features. Journal of Affective Disorders 73, 283-287.

Keller J, Schatzberg AF, Maj M (2007). Current issues in the classification of psychotic major depression. Schizophrenia Bulletin 33, 877-885.

Kessler RC, Bromet EJ (2013). The epidemiology of depression across cultures. The Annual Review of Public Health 34, 119-138.

Kivelä SL, Pahkala K (1989). Delusional depression in the elderly: a community study. Zeitschrift fur Gerontologie 22, 236-241.

Kruijshaar ME, Hoeymans N, Bijl RV, Spijker J, Essink-Bot ML (2003). Levels of disability in 
major depression: findings from the Netherlands Mental Health Survey and Incidence Study (NEMESIS). Journal of Affective Disorders 77, 53-64.

Leadholm AK, Rothschild AJ, Nolen WA, Bech P, Munk-Jørgensen P, Ostergaard SD (2013). The treatment of psychotic depression: is there consensus among guidelines and psychiatrists? Journal of Affective Disorders 145, 214-220.

Lykouras L, Gournellis R (2009). Psychotic (delusional) major depression: new vistas. Current Psychiatry Reviews 5, 1-28.

Maj M, Pirozzi R, Magliano L, Fiorillo A, Bartoli L (2007). Phenomenology and prognostic significance of delusions in major depressive disorder: a 10-year prospective follow-up study. The Journal of Clinical Psychiatry 68, 1411-1417.

Matheson SL, Shepherd AM, Carr VJ (2014). How much do we know about schizophrenia and how well do we know it? Evidence from the Schizophrenia Library. Psychological Medicine 20, 1-19.

Moher D, Liberati A, Tetzlaff J, Altman DG, PRISMA Group (2009). Preferred reporting items for systematic reviews and meta-analyses: the PRISMA statement. PLOS Medicine 6:e1000097.

Nakamura K, Iga J, Matsumoto N, Ohmori T (2015). Risk of bipolar disorder and psychotic features in patients initially hospitalised with severe depression. Acta Neuropsychiatrica 27, 113-118.

Nelson JC, Davis JM (1997). DST studies in psychotic depression: a meta-analysis. The American Journal of Psychiatry 154, 1497-1503.

Ohayon MM, Schatzberg AF (2002). Prevalence of depressive episodes with psychotic features in the general population. The American Journal of Psychiatry 159, 1855-1861.

Okulate GT, Oladapo HT, Osibogun A (2001). Comparison of three subtypes of depression. The Nigerian Postgraduate Medical Journal 8, 41-45.

Olesen J, Gustavsson A, Svensson M, Wittchen HU, Jönsson B; CDBE2010 study group; European Brain Council (2012). The economic cost of brain disorders in Europe. European Journal of Neurology 19, 155-162.

Opjordsmoen S (1991). Unipolar delusional depression. Outcome in reactive versus endogenous types. Psychopathology 24, 260-269.

Ormel J, Oldehinkel AJ, Nolen WA, Vollebergh W (2004). Psychosocial disability before, during, and after a major depressive episode: a 3-wave population-based study of state, scar, and trait effects. Archives of General Psychiatry 61, 387-392.

Østergaard SD, Straszek S, Petrides G, Skadhede S, Jensen SO, Munk-Jørgensen P, Nielsen $\mathbf{J}$ (2014). Risk factors for conversion from unipolar psychotic depression to bipolar disorder. Bipolar Disorders 16, 180-189.

Østergaard SD, Waltoft BL, Mortensen PB, Mors O (2013). Environmental and familial risk factors for psychotic and non-psychotic severe depression. Journal of Affective Disorders $147,232-240$.

Park SC, Choi J, Kim JM, Jun TY, Lee MS, Kim JB, Yim HW, Park YC (2014). Is the Psychotic Depression Assessment Scale a useful diagnostic tool? The CRESCEND study. Journal of 
Affective Disorders 166, 79-85.

Parker G, Hadzi-Pavlovic D, Hickie I, Mitchell P, Wilhelm K, Brodaty H, Boyce P, Eyers K, Pedic F (1991). Psychotic depression: a review and clinical experience. The Australian and New Zealand Journal of Psychiatry 25, 169-180.

Penttilä M, Jääskeläinen E, Hirvonen N, Isohanni M, Miettunen J (2014). Duration of untreated psychosis as predictor of long-term outcome in schizophrenia: systematic review and metaanalysis. British Journal of Psychiatry 205, 88-94.

Perälä J, Suvisaari J, Saarni SI, Kuoppasalmi K, Isometsä E, Pirkola S, Partonen T, TuulioHenriksson A, Hintikka J, Kieseppä T, Härkänen T, Koskinen S, Lönnqvist J (2007). Lifetime prevalence of psychotic and bipolar I disorders in a general population. Archives of General Psychiatry 64, 19-28.

Reay R, Mitford E, McCabe K, Paxton R, Turkington D (2019). Incidence and diagnostic diversity in first-episode psychosis. Acta Psychiatrica Scandinavica 121, 315-319.

Rothschild AJ (2009). Clinical Manual for Diagnosis and Treatment of Psychotic Depression. American Psychiatric Publishing Inc.: Washington DC.

Rothschild AJ, Winer J, Flint AJ, Mulsant BH, Whyte EM, Heo M, Fratoni S, Gabriele M, Kasapinovic S, Meyers BS (2008). Study of Pharmacotherapy of Psychotic Depression (STOP-PD) Collaborative Study Group. Missed diagnosis of psychotic depression at 4 academic medical centers. Journal of Clinical Psychiatry 69, 1293-1296.

Ruggero CJ, Kotov R, Carlson GA, Tanenberg-Karant M, Gonzalez DA, Bromet EJ (2011). Diagnostic consistency of major depression with psychosis across 10 years. The Journal of Clinical Psychiatry 72, 1207-1213.

Rush AJ, Carmody TJ, Ibrahim HM, Trivedi MH, Biggs MM, Shores-Wilson K, Crismon ML, Toprac MG, Kashner TM (2006). Comparison of self-report and clinician ratings on two inventories of depressive symptomatology. Psychiatric Services 57, 829-837.

Ryan ND, Puig-Antich J, Ambrosini P, Rabinovich H, Robinson D, Nelson B, lyengar S, Twomey $\mathbf{J}$ (1987). The clinical picture of major depression in children and adolescents. Archives of General Psychiatry 44, 854-861.

Saarni SI, Viertio S, Perälä J, Koskinen S, Lönnqvist J, Suvisaari J (2010). Quality of life of people with schizophrenia, bipolar disorder and other psychotic disorders. The British Journal of Psychiatry 197, 386-394.

Salvatore P, Baldessarini RJ, Tohen M, Khalsa HM, Sanchez-Toledo JP, Zarate CA,Jr, Vieta E, Maggini C (2011). McLean-Harvard International First-Episode Project: two-year stability of ICD-10 diagnoses in 500 first-episode psychotic disorder patients. The Journal of Clinical Psychiatry 72, 183-193.

Sands JR, Harrow M (1995). Vulnerability to psychosis in unipolar major depression: is premorbid functioning involved? The American Journal of Psychiatry 152, 1009-1015.

Schatzberg AF, Rothschild AJ (1992). Psychotic (delusional) major depression: should it be included as a distinct syndrome in DSM-IV? The American Journal of Psychiatry 149, 733745.

Sherazi R, McKeon P, McDonough M, Daly I, Kennedy N (2006). What's new? The clinical epidemiology of bipolar I disorder. Harvard Review of Psychiatry 14, 273-284. 
Simpson S, Baldwin RC, Jackson A, Burns A (1999). The differentiation of DSM-III-R psychotic depression in later life from nonpsychotic depression: comparisons of brain changes measured by multispectral analysis of magnetic resonance brain images, neuropsychological findings, and clinical features. Biological Psychiatry 45, 193-204.

Souery D, Zaninotto L, Calati R, Linotte S, Sentissi O, Amital D, Moser U, Kasper S, Zohar J, Mendlewicz J, Serretti A (2011). Phenomenology of psychotic mood disorders: lifetime and major depressive episode features. Journal of Affective Disorders 135, 241-250.

StataCorp (2013). Stata Statistical Software: Release 13. College Station: StataCorp LP.

Sterne J (2009). Meta-Analysis in Stata: An Updated Collection from the Stata Journal. College Station: Stata Press.

Suvisaari J, Partti K, Perälä J, Viertio S, Saarni SE, Lönnqvist J, Saarni SI, Härkänen T (2013). Mortality and its determinants in people with psychotic disorder. Psychosomatic Medicine 75, 60-67.

Tohen M, Khalsa HM, Salvatore P, Vieta E, Ravichandran C, Baldessarini RJ (2012). Twoyear outcomes in first-episode psychotic depression the McLean-Harvard First-Episode Project. Journal of Affective Disorders 136, 1-8.

Tohen M, Strakowski SM, Zarate C,Jr, Hennen J, Stoll AL, Suppes T, Faedda GL, Cohen BM, Gebre-Medhin P, Baldessarini RJ (2000). The McLean-Harvard first-episode project: 6month symptomatic and functional outcome in affective and nonaffective psychosis. Biological Psychiatry 48, 467-476.

Vythilingam M, Chen J, Bremner JD, Mazure CM, Maciejewski PK, Nelson JC (2003). Psychotic depression and mortality. The American Journal of Psychiatry 160, 574-576.

WHO (1992). International Classification of Diseases and Related Health Problems. 10th revision. World Health Organization: Geneva.

Wijkstra J, Lijmer J, Burger H, Cipriani A, Geddes J, Nolen WA (2015). Pharmacological treatment for psychotic depression. The Cochrane Database of Systematic Reviews 7:CD004044. Doi: CD004044.

Zalpuri I, Rothschild AJ (2016). Does psychosis increase the risk of suicide in patients with major depression? A systematic review. Journal of Affective Disorders 198, 23-31.

Zaninotto L, Guglielmo R, Calati R, loime L, Camardese G, Janiri L, Bria P, Serretti A (2015). Cognitive markers of psychotic unipolar depression: a meta-analytic study. Journal of Affective Disorders 174, 580-588. 
Table 1. Summary of the main results.

Topic Main result

\section{Occurrence}

Annual incidence

Lifetime prevalence

Point prevalence

Proportion of all depressions

\section{Gender}

\section{Onset age}

\section{Risk factors}

\section{Outcomes}

Depression symptoms

Psychosis symptoms

Positive symptoms

Negative symptoms

Symptomatic remission

Clinical global outcome

Relapses

Global outcome

Occupational outcomes
0.21-6.4/100 000 (higher in females).

$0.35-1.0 \%$ (higher in older samples and females).

$0.5 \%$ (higher in females).

$28 \%$ of all depressive patients, being higher in older samples and among inpatients.

Appr. $65 \%$ of the PD patients were females, this was comparable to NPD but higher than especially in SZ.

No significant difference in onset age in PD versus NPD. Among youngest samples PD patients had earlier onset age, whereas in oldest samples PD patients had later onset age compared to NPD. SZ patients had younger age of illness onset than PD patients.

Lack of studies on early risk factors.

Individuals with PD were less likely to be Caucasian and had more often family history of psychosis and bipolar I disorder when compared to NPD patients. Differences in educational level and marital status between PD and NPD were mostly non-significant.

more severe in PD compared to NPD

no difference in PD compared to SZ and PBD

more severe in PD compared to NPD

less severe in PD compared to SZ

less severe in PD compared to SZ and PBD

less severe in PD compared to SZ

more severe in $\mathrm{PD}$ compared to $\mathrm{PBD}$

somewhat less common in PD than NPD

more common in PD compared to SZAFF

somewhat poorer in PD than NPD

higher in PD compared to NPD

lower in $\mathrm{PD}$ compared to $\mathrm{SZ}$

relatively similar in PD and PBD

somewhat worse in PD compared to NPD

better in PD compared to SZ

no difference between PD and PBD

somewhat poorer in PD, but in many studies also similar to NPD

better in PD compared to SZ and SZAFF

relatively similar in $\mathrm{PD}$ and $\mathrm{PBD}$

Diagnoses: $\mathrm{PD}=$ psychotic depression, NPD = nonpsychotic depression, $\mathrm{PD}=$ bipolar disorder, $\mathrm{PBD}=$ psychotic bipolar disorder, $\mathrm{SZ}=$ schizophrenia, SZAFF = schizoaffective disorder 
Fig. 1. Flow diagram of the selection of studies.

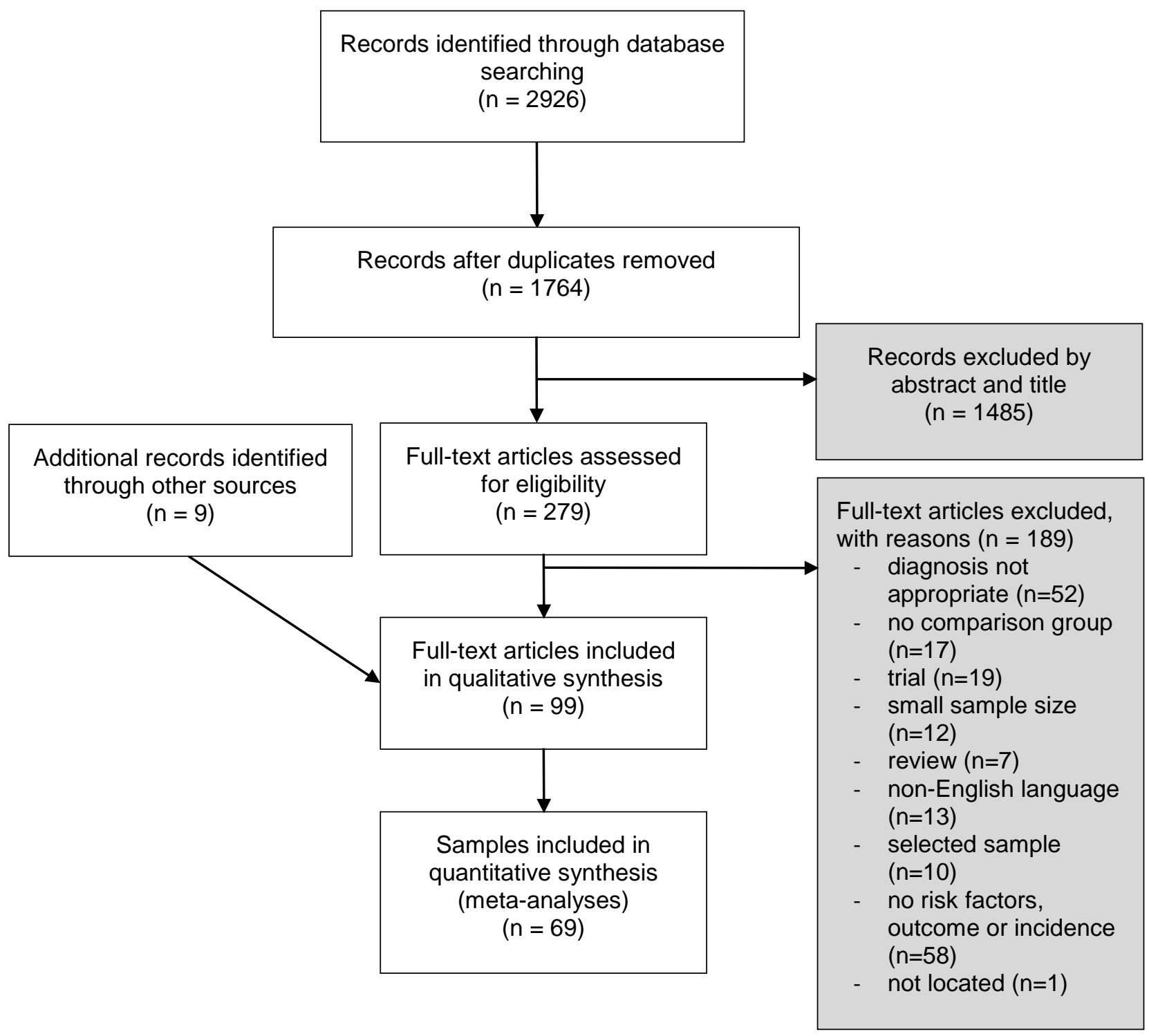


Fig. 2. Forest plot for estimated or relative rates $(R R)$ psychotic depression among females in depression patients. Studies are grouped and analyzed separately by mean study age.

\section{Risk of psychosis among females in depression}

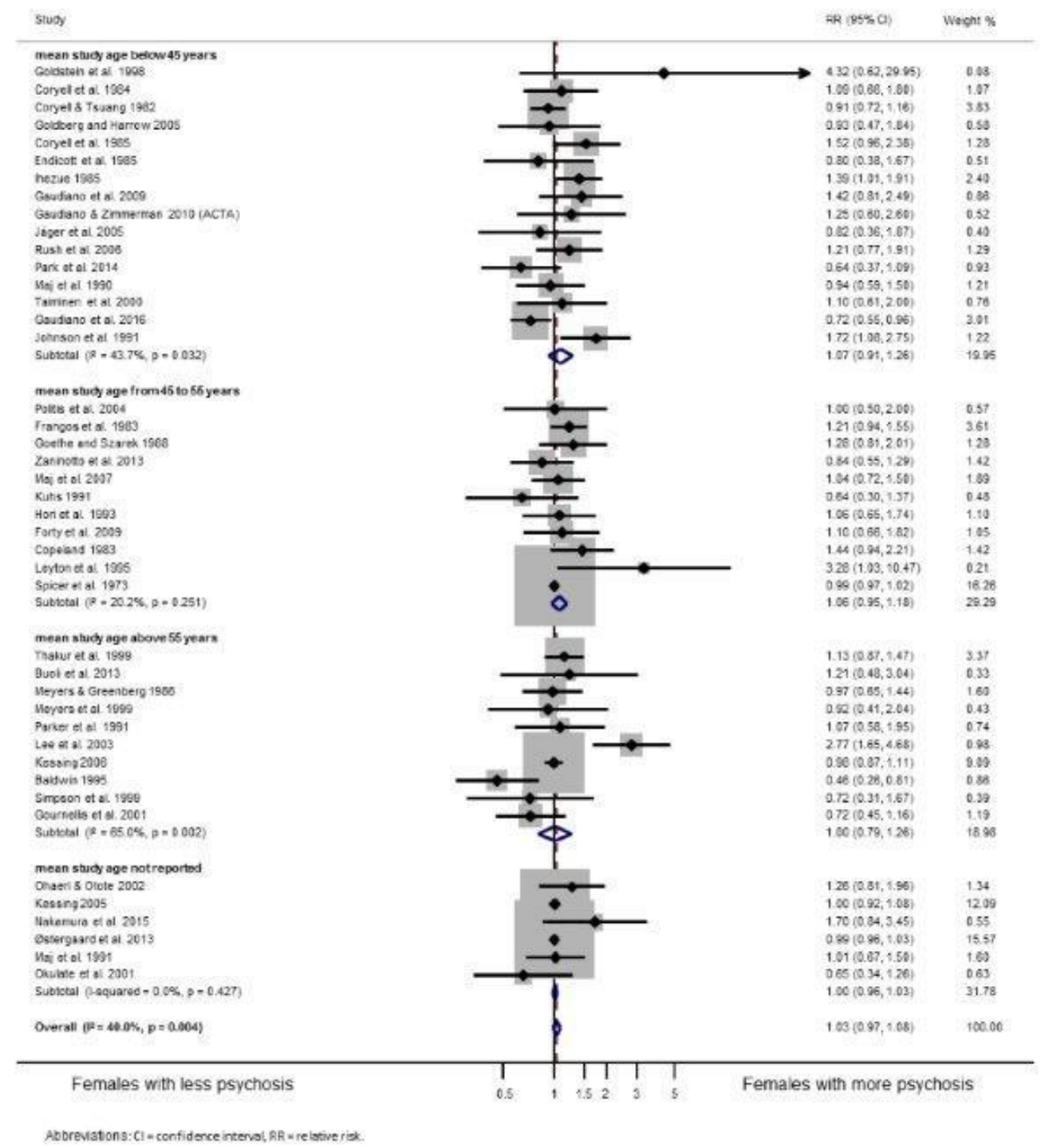


Fig. 3. Forest plot comparing mean onset age between psychotic depression and non-psychotic depression. Studies are grouped and analyzed separately by mean study age.

\section{Mean difference in onset age between PD and NPD}

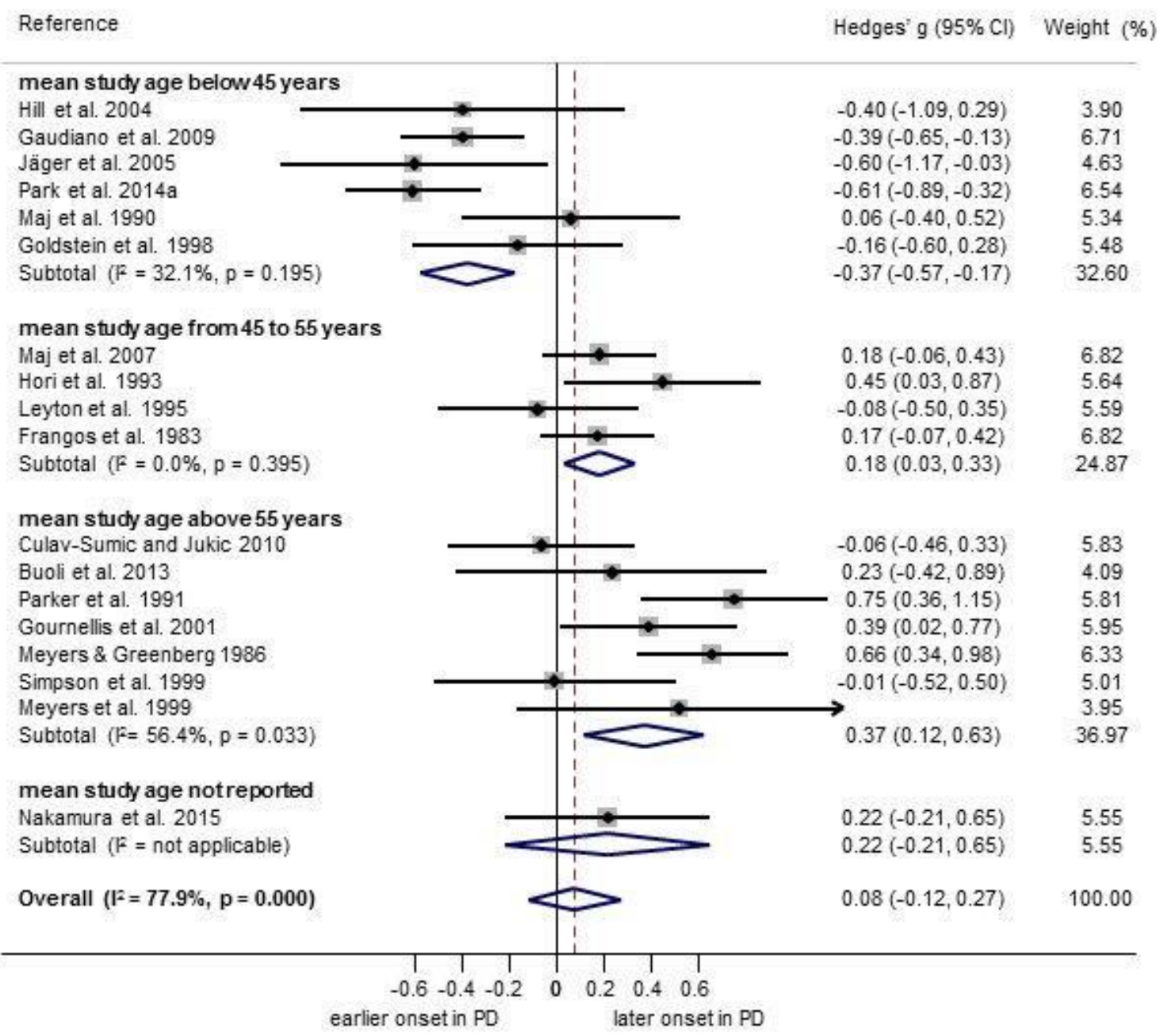

Abbreviations: $\mathrm{PD}=$ psychotic depression, $\mathrm{NPD}=$ non-psychotic depression, $\mathrm{l}^{2}=$ heterogeneity, $\mathrm{Cl}=$ confidence interval. 


\begin{tabular}{|c|c|c|c|c|}
\hline Reference & Country & Diagnosis & Comments & Results \\
\hline $\begin{array}{l}\text { Community studies } \\
\text { Johnson et al. } 1991\end{array}$ & $\begin{array}{l}\text { USA } \\
(1980- \\
1984)\end{array}$ & DSM-III & $\begin{array}{l}\text { Part of the Epidemiological Catchment Area } \\
\text { (ECA) study ( } n=14212 \text { ). Community sample } \\
\text { of those with age of } 18 \text { or more living in five } \\
\text { US cities (New Haven, St. Louis, Baltimore, } \\
\text { Durham, Los Angeles). Diagnostic Interview } \\
\text { Schedule was used as a screen, people were } \\
\text { given a psychotic depression diagnosis if } \\
\text { they had MDD in the depression module and } \\
\text { endorsed psychotic symptoms in the } \\
\text { psychosis module. }\end{array}$ & $\begin{array}{l}\text { Lifetime prevalence rate for PD was in the } \\
\text { total sample } 0.6 \% \text { (varying between } 0.3 \text { and } \\
0.8 \text { in different cities). Validity of the used } \\
\text { psychotic depression diagnosis was poor. }\end{array}$ \\
\hline $\begin{array}{l}\text { Kivelä \& Pahkala, } \\
1989\end{array}$ & $\begin{array}{l}\text { Finland } \\
(1984- \\
1986)\end{array}$ & DSM-III & $\begin{array}{l}\text { Community based study in Ähtäri, Finland, of } \\
\text { those with } 60 \text { years or more }(n=594) \text {. Zung } \\
\text { Self-Rating Depression Scale was used as a } \\
\text { screen. }\end{array}$ & $\begin{array}{l}\text { Prevalence } 1.0 \% \text { for total sample }(0.6 \% \text { for } \\
\text { males, } 1.2 \% \text { for females). }\end{array}$ \\
\hline $\begin{array}{l}\text { Ohayon \& } \\
\text { Schatzberg, } 2002\end{array}$ & $\begin{array}{l}\text { Several } \\
\text { European } \\
\text { countries } \\
(1994- \\
1999)\end{array}$ & DSM-IV & $\begin{array}{l}\text { Telephone survey of } 18980 \text { people between } \\
\text { ages } 15-100 . \text { Sleep-EVAL expert system } \\
\text { covering DSM-IV was used as diagnostic } \\
\text { instrument. }\end{array}$ & $\begin{array}{l}\text { The overall point prevalence for PD was } \\
0.5 \% \text {. The point prevalence for PD was } 0.5 \% \\
\text { in the United Kingdom, } 0.4 \% \text { in Germany, } \\
0.2 \% \text { in Italy, } 0.5 \% \text { in Portugal, and } 0.2 \% \text { in } \\
\text { Spain. Point prevalence estimates by gender, } \\
\text { age, marital status and occupation were also } \\
\text { reported, significantly higher rates were } \\
\text { reported for females ( } 0.6 \% \text { ) than males } \\
(0.3 \%) \text {. Unemployed persons had prevalence } \\
\text { of } 1.2 \% \text {, which differed from other occupation } \\
\text { groups (e.g. } 0.3 \% \text { among daytime workers). }\end{array}$ \\
\hline Perälä et al. 2007 & $\begin{array}{l}\text { Finland } \\
(2000- \\
2001)\end{array}$ & DSM-IV & $\begin{array}{l}\text { Nationally representative Finnish Health } 2000 \\
\text { sample (age } 30 \text { or older, } \mathrm{n}=8028 \text { ). The study } \\
\text { used information from Composite } \\
\text { International Diagnostic Interview and from } \\
\text { other sources (self-reported diagnoses, } \\
\text { medical examination and national register) as } \\
\text { a screen. }\end{array}$ & $\begin{array}{l}\text { Lifetime prevalence } 0.35 \% \text { (males } 0.41 \% \text {, } \\
\text { females } 0.29 \%) \text {. By age: } 30-44 y \text { (Total } \\
0.30 \% \text {, males } 0.30 \% \text {, females } 0.30 \%), 45- \\
54 y(0.36 \% \text {, males } 0.52 \% \text {, females } 0.21 \%) \text {, } \\
55-64 y(0.31 \% \text {, males } 0.33 \% \text {, females } \\
0.30 \%), 65 y \text { or more }(0.43 \% \text {, males } 0.54 \% \text {, } \\
\text { females } 0.36 \%) \text {. Differences by age group or } \\
\text { by sex within an age group were not } \\
\text { statistically significant. }\end{array}$ \\
\hline \multicolumn{5}{|l|}{$\begin{array}{l}\text { Studies based on } \\
\text { in- and outpatient } \\
\text { admissions }\end{array}$} \\
\hline Farquhar et al. 2007 & $\begin{array}{l}\text { UK }(1875- \\
1924\end{array}$ & ICD-10 & Admissions in North West Wales, UK. & $\begin{array}{l}\text { Annual incidence } 3.4 \text { per } 100.000 \text { persons in } \\
1875-1924 \text { and } 3.0 \text { per } 100.000 \text { in } 1995-\end{array}$ \\
\hline
\end{tabular}




\begin{tabular}{|c|c|c|c|c|}
\hline & $\begin{array}{l}1995- \\
2005)\end{array}$ & & & 1999. \\
\hline Pederson et al. 1972 & $\begin{array}{l}\text { USA } \\
(1961- \\
1962)\end{array}$ & DSM-I & $\begin{array}{l}\text { Psychiatric case register in Monroe County, } \\
\text { New York, USA. }\end{array}$ & $\begin{array}{l}\text { Overall age-adjusted yearly prevalence rate } \\
\text { was } 0.70 / 1000 / \text { year (men } 0.53 \text {, women } 0.87 \text { ), } \\
\text { whereas overall age-adjusted two-year } \\
\text { incidence rate was } 0.33 / 1000 / \text { year (men } \\
0.27 \text {, women } 0.37 \text { ). }\end{array}$ \\
\hline Filatova et al. 2016 & $\begin{array}{l}\text { Finland } \\
(1980- \\
1993 \\
2000- \\
2013)\end{array}$ & $\begin{array}{l}\text { ICD-9, ICD- } \\
10\end{array}$ & $\begin{array}{l}\text { Compares two Northern Finland Birth } \\
\text { cohorts, born } 1966 \text { (NFBC1966) and } 1986 \\
\text { (NFBC1986). Total sample size 12058 } \\
\text { (NFBC1966) and } 9432 \text { (NFBC1986). }\end{array}$ & $\begin{array}{l}\text { Cumulative incidence until age } 27 \text { was } 0.02 \% \\
\text { in NFBC1966 and } 0.21 \% \text { in NFBC1986 } \\
(p<0.001) .\end{array}$ \\
\hline $\begin{array}{l}\text { Baldwin et al. 2005; } \\
\text { Owoeye et al. } 2013\end{array}$ & $\begin{array}{l}\text { Ireland } \\
\text { (1995- } \\
2003)\end{array}$ & DSM-IV & $\begin{array}{l}\text { The Cavan-Monaghan First Episode Study. } \\
\text { Population } n=103054 \text {. }\end{array}$ & $\begin{array}{l}\text { Annual incidence (per } 100,000 \text { population } \\
\text { aged }>15 \text { ) was } 6.4 \text { (males } 5.4 \text { and females } \\
7.4 \text { ). In the follow-up study of } 6 \text { months, an } \\
\text { incidence of } 6.9 \text { (males } 6.5 \text {, females } 7.4 \text { ) per } \\
100,000 \text { of population was reported. }\end{array}$ \\
\hline $\begin{array}{l}\text { Reay et al. 2010; } \\
\text { Crebbin et al. } 2008\end{array}$ & $\begin{array}{l}\text { UK (1998- } \\
2005)\end{array}$ & ICD-10 & $\begin{array}{l}\text { Used Census } 2001 \text { to estimate population. } \\
\text { Used inpatient and outpatient admissions } \\
\text { (age } 16 \text { or more) in Northumberland, UK. }\end{array}$ & $\begin{array}{l}\text { Incidence per } 100000 \text { for those with } 16 \\
\text { years and over: was } 6.0 \text { (in age group 16-64 } \\
\text { it was 5.4). PD was less common than NPD } \\
\text { in younger people (under } 36 \text { years). }\end{array}$ \\
\hline
\end{tabular}


Supplement Table 2. Proportion of female patients in studies comparing psychotic depression with non-psychotic depression, schizophrenia or psychotic bipolar disorder.

\begin{tabular}{|c|c|c|c|c|c|c|c|c|c|c|c|c|}
\hline \multirow[t]{2}{*}{ Reference } & \multirow[t]{2}{*}{ Country } & \multirow[t]{2}{*}{ Diagnosis } & \multicolumn{2}{|c|}{$\begin{array}{c}\text { Psychotic } \\
\text { depression }\end{array}$} & \multicolumn{2}{|c|}{$\begin{array}{l}\text { Non-psychotic } \\
\text { depression }\end{array}$} & \multicolumn{2}{|c|}{ Schizophrenia } & \multicolumn{2}{|c|}{$\begin{array}{c}\begin{array}{c}\text { Schizoaffective } \\
\text { disorder }\end{array} \\
\end{array}$} & \multicolumn{2}{|c|}{$\begin{array}{c}\text { Psychotic } \\
\text { bipolar disorder }\end{array}$} \\
\hline & & & $\mathrm{N}$ & Females & $\mathrm{N}$ & Females & $\mathrm{N}$ & Females & $\mathrm{N}$ & Females & $\mathrm{N}$ & Females \\
\hline Baldwin 1995 & UK & DSM-III-R & 34 & $53 \%$ & 100 & $77 \%$ & & & & & & \\
\hline Beiser et al. 1993 & Canada & DSM-III & 30 & $37 \%$ & & & 72 & $22 \%$ & & & 39 & $44 \%$ \\
\hline Benazzi 1999 & Italy & DSM-IV & 40 & $55 \%$ & & & & & & & 30 & $63 \%$ \\
\hline Breslau \& Meltzer, 1988 & USA & RDC & 39 & $64 \%$ & & & & & 34 & $65 \%$ & 38 & $68 \%$ \\
\hline Buoli et al. 2013 & Italy & DSM-IV-TR & 18 & $83 \%$ & 18 & $78 \%$ & & & & & & \\
\hline Copeland, 1983 & UK & own system & 55 & $75 \%$ & 39 & $56 \%$ & & & & & & \\
\hline Coryell \& Tsuang, 1982 & USA & Feighner & 122 & $53 \%$ & 103 & $58 \%$ & & & & & & \\
\hline $\begin{array}{l}\text { Coryell \& Zimmerman, } \\
1988\end{array}$ & USA & $\mathrm{RDC}$ & 29 & $62 \%$ & & & 21 & $24 \%$ & 47 & $62 \%$ & & \\
\hline Coryell et al. 1984b & USA & DSM-III & 55 & $71 \%$ & 180 & $67 \%$ & & & & & & \\
\hline Coryell et al. 1985a & USA & DSM-III & 76 & $68 \%$ & 473 & $57 \%$ & & & & & & \\
\hline Coryell et al. 1990a & USA & RDC & 92 & $65 \%$ & & & & & 42 & $64 \%$ & & \\
\hline Craig \& Bromet, 2004 & USA & DSM-IV & 87 & $59 \%$ & & & 227 & $35 \%$ & & & 139 & $50 \%$ \\
\hline Craig et al. 2000 & USA & DSM-IV & 75 & $60 \%$ & & & 155 & $34 \%$ & & & 119 & $52 \%$ \\
\hline Crebbin et al. 2008 & UK & ICD-10 & 105 & $54 \%$ & & & 73 & $34 \%$ & & & & \\
\hline Dell'Osso et al. 2002 & Italy & DSM-III-R & 30 & $67 \%$ & & & & & & & 147 & $55 \%$ \\
\hline Endicott et al. 1985 & USA & RDC & 26 & $62 \%$ & 178 & $67 \%$ & & & & & 102 & $56 \%$ \\
\hline Forty et al. 2009 & UK & $\begin{array}{l}\text { DSM-IV, } \\
\text { ICD-10 }\end{array}$ & 64 & $70 \%$ & 460 & $68 \%$ & & & & & & \\
\hline Frangos et al. 1983 & Greece & $\mathrm{RDC}$ & 145 & $70 \%$ & 119 & $61 \%$ & & & & & & \\
\hline $\begin{array}{l}\text { Gaudiano \& } \\
\text { Zimmerman, } 2010\end{array}$ & USA & DSM-IV & 32 & $69 \%$ & 591 & $63 \%$ & & & & & & \\
\hline Gaudiano et al. 2009 & USA & DSM-IV & 60 & $73 \%$ & 1052 & $66 \%$ & & & & & & \\
\hline Gaudiano et al. 2016 & USA & DSM-IV-TR & 174 & $57 \%$ & 1140 & $66 \%$ & & & & & & \\
\hline Goethe \& Szarek, 1988 & USA & DSM-III & 77 & $71 \%$ & 360 & $65 \%$ & & & & & & \\
\hline $\begin{array}{l}\text { Goldberg \& Harrow, } \\
2005\end{array}$ & USA & $\mathrm{RDC}$ & 27 & $63 \%$ & 95 & $65 \%$ & & & & & & \\
\hline Goldstein et al. 1998 & USA & $\mathrm{RDC}$ & 25 & $96 \%$ & 93 & $82 \%$ & & & & & & \\
\hline Gournellis et al. 2001 & Greece & DSM-IV & 45 & $69 \%$ & 73 & $79 \%$ & & & & & & \\
\hline Heslin et al. 2016 & UK & ICD-10 & 72 & $50 \%$ & & & 218 & $36 \%$ & & & 70 & $53 \%$ \\
\hline Hill et al. 2004 & USA & $\begin{array}{l}\text { DSM-III-R, } \\
\text { DSM-IV }\end{array}$ & 20 & $55 \%$ & & & 86 & $38 \%$ & & & & \\
\hline Hori et al. 1993 & Japan & DSM-III-R & 38 & $55 \%$ & 55 & $53 \%$ & & & & & & \\
\hline
\end{tabular}




\begin{tabular}{|c|c|c|c|c|c|c|c|c|c|c|c|c|}
\hline Ihezue, 1985 & Nigeria & ICD-9 & 78 & $63 \%$ & 64 & $45 \%$ & & & & & & \\
\hline Jarbin et al. 2003 & Sweden & DSM-IV & 17 & $53 \%$ & & & 32 & $34 \%$ & & & 25 & $64 \%$ \\
\hline Johnson et al. 1991 & USA & DSM-III & 114 & $83 \%$ & 662 & $73 \%$ & & & & & & \\
\hline Jäger et al. 2005 & Germany & DSM-IV & 20 & $80 \%$ & 33 & $85 \%$ & 64 & $56 \%$ & & & & \\
\hline Karaaslan et al. 2003 & Turkey & DSM-IV & 16 & $50 \%$ & & & & & & & 20 & $40 \%$ \\
\hline Kessing, 2005 & Denmark & ICD-10 & 1497 & $66 \%$ & 2962 & $62 \%$ & & & & & & \\
\hline Kessing, 2006 & Denmark & ICD-10 & 705 & $66 \%$ & 1044 & $66 \%$ & & & & & & \\
\hline Kuhs, 1991 & Germany & $\begin{array}{l}\text { ICD-9, DSM- } \\
\text { III }\end{array}$ & 23 & $48 \%$ & 137 & $61 \%$ & & & & & & \\
\hline Lee et al. 2003 & Taiwan & DSM-IV & 48 & $69 \%$ & 108 & $33 \%$ & & & & & & \\
\hline Leyton et al. 1995 & Canada & DSM-III-R & 25 & $88 \%$ & 140 & $66 \%$ & & & & & & \\
\hline Maj et al. 1990 & Italy & DSM-III & 36 & $58 \%$ & 36 & $61 \%$ & & & & & & \\
\hline Maj et al. 1991 & Italy & DSM-III-R & 41 & $63 \%$ & 27 & $63 \%$ & 28 & $54 \%$ & 21 & $57 \%$ & & \\
\hline Maj et al. 2007 & Italy & DSM-III & 89 & $62 \%$ & 240 & $60 \%$ & & & & & & \\
\hline $\begin{array}{l}\text { Meyers \& Greenberg, } \\
1986\end{array}$ & USA & DSM-III & 72 & $76 \%$ & 89 & $78 \%$ & & & & & & \\
\hline Meyers et al. 1999 & USA & DSM-III-R & 15 & $67 \%$ & 20 & $70 \%$ & & & & & & \\
\hline Nakamura et al. 2015 & Japan & ICD-10 & 33 & $79 \%$ & 56 & $63 \%$ & & & & & & \\
\hline Ohaeri \& Otote, 2002 & ICD-10 & Nigeria & 51 & $73 \%$ & 45 & $62 \%$ & & & & & & \\
\hline Okulate et al. 2001 & ICD-10 & Nigeria & 31 & $39 \%$ & 144 & $51 \%$ & & & & & & \\
\hline Opjordsmoen, 1991 & Norway & DSM-III & 50 & $60 \%$ & & & & & 33 & $45 \%$ & & \\
\hline Østergaard et al. 2013a & Denmark & ICD-10 & 8260 & $65 \%$ & 15913 & $65 \%$ & & & & & & \\
\hline Owoeye et al. 2013 & Ireland & DSM-IV & 77 & $53 \%$ & & & 73 & $26 \%$ & & & 54 & $52 \%$ \\
\hline Park et al. 2014a & $\begin{array}{l}\text { South } \\
\text { Korea }\end{array}$ & DSM-IV & 53 & $68 \%$ & 441 & $78 \%$ & & & & & & \\
\hline Parker et al. 1991 & Australia & $\begin{array}{l}\text { DSM-III, } \\
\text { RDC }\end{array}$ & 35 & $66 \%$ & 102 & $64 \%$ & & & & & & \\
\hline Politis et al. 2004 & Greece & DSM-IV & 16 & $50 \%$ & 16 & $50 \%$ & 20 & $40 \%$ & & & & \\
\hline Rush et al. 2006 & USA & DSM-IV & 106 & $82 \%$ & 438 & $78 \%$ & & & & & & \\
\hline Rybakowski et al. 2007 & Poland & DSM-IV & 26 & $81 \%$ & & & & & & & 92 & $60 \%$ \\
\hline Simpson et al. 1999 & UK & DSM-III-R & 18 & $61 \%$ & 81 & $70 \%$ & & & & & & \\
\hline Spicer et al. 1973 & UK & ICD-9 & 14972 & $68 \%$ & 13844 & $68 \%$ & & & & & & \\
\hline Taiminen et al. 2000 & Finland & DSM-IV & 23 & $57 \%$ & 25 & $52 \%$ & 17 & $71 \%$ & & & & \\
\hline Thakur et al. 1999 & USA & DSM-III-R & 189 & $67 \%$ & 485 & $63 \%$ & & & & & & \\
\hline Zaninotto et al. 2013 & $\begin{array}{l}\text { European } \\
\text { multicenter }\end{array}$ & DSM-IV & 90 & $72 \%$ & 609 & $76 \%$ & & & & & & \\
\hline
\end{tabular}

a Overlapping samples, but different comparison group. Abbreviations: DSM = Diagnostic and Statistical Manual of Mental disorders, ICD = International

Classification of Diseases, RDC = Research Diagnostic Criteria. 
Supplement Table 3. Mean and Standard deviation (SD) of onset age of illness in studies comparing psychotic depression and nonpsychotic depression, schizophrenia or psychotic bipolar disorder.

\begin{tabular}{|c|c|c|c|c|c|c|c|c|c|c|c|c|c|c|c|}
\hline \multirow[t]{2}{*}{ Reference } & \multirow[t]{2}{*}{ Country } & \multirow[t]{2}{*}{ Diagnosis } & \multirow[t]{2}{*}{$\begin{array}{l}\text { Study } \\
\text { design }\end{array}$} & \multicolumn{3}{|c|}{$\begin{array}{l}\text { Psychotic } \\
\text { depression }\end{array}$} & \multicolumn{3}{|c|}{$\begin{array}{l}\text { Non-psychotic } \\
\text { depression }\end{array}$} & \multicolumn{3}{|c|}{$\begin{array}{c}\text { Schizophrenia / } \\
\text { schizoaffective } \\
\text { disorder }^{\text {a }}\end{array}$} & \multicolumn{3}{|c|}{$\begin{array}{l}\text { Psychotic bipolar } \\
\text { disorder }\end{array}$} \\
\hline & & & & $\mathrm{N}$ & mean & SD & $\mathrm{N}$ & mean & SD & $\mathrm{N}$ & mean & SD & $\mathrm{N}$ & mean & SD \\
\hline \multicolumn{16}{|l|}{ First-episode samples } \\
\hline Baldwin et al. 2005 & Ireland & DSM-IV & First-episode & 39 & 45.6 & 22.3 & & & & 66 & 31.3 & 16.6 & 32 & 34.8 & 16.2 \\
\hline $\begin{array}{l}\text { Breslau \& Meltzer, } \\
1988^{\mathrm{b}}\end{array}$ & USA & $\mathrm{RDC}$ & First-episode & 22 & 26.3 & 11.2 & & & & 22 & 24.8 & 9.7 & 22 & 23.6 & 7.4 \\
\hline Hill et al. 2004 & USA & $\begin{array}{l}\text { DSM-III-R. } \\
\text { DSM-IV }\end{array}$ & First-episode & 20 & 25.2 & 8.8 & 14 & 29.0 & 10.1 & 86 & 28.6 & 9.6 & & & \\
\hline Husted et al. 1995 & Canada & DSM-III & First-episode & 35 & 26.3 & 8.1 & & & & 91 & 22.6 & 5.8 & 38 & 26.3 & 7.9 \\
\hline $\begin{array}{l}\text { Nakamura et al. } \\
2015\end{array}$ & Japan & ICD-10 & First-episode & 33 & 51.5 & 16.3 & 56 & 48.1 & 14.9 & & & & & & \\
\hline $\begin{array}{l}\text { Owoeye et al. } 2013 \\
\text { Consecutive or mixec }\end{array}$ & $\begin{array}{l}\text { Ireland } \\
\text { samples }\end{array}$ & DSM-IV & First-episode & 77 & 51.2 & 22.0 & & & & 73 & 30.9 & 14.5 & 54 & 31.9 & 13.9 \\
\hline Benazzi, 1999 & Italy & DSM-IV & Mixed & 40 & 35.8 & 15.0 & & & & & & & 30 & 33.5 & 13.3 \\
\hline Buoli et al. 2013 & Italy & DSM-IV-TR & Mixed & 18 & 41.8 & 17.1 & 18 & 38.1 & 13.5 & & & & & & \\
\hline $\begin{array}{l}\text { Čulav-Sumić \& Jukić, } \\
2010\end{array}$ & Croatia & ICD-10 & Consecutive & 50 & 39.3 & 13.4 & 50 & 40.1 & 11.5 & & & & & & \\
\hline Dell'Osso et al. 2002 & Italy & DSM-III-R & Mixed & 30 & 36.2 & 12.7 & & & & & & & 147 & 36.5 & 12.3 \\
\hline Frangos et al. 1983 & Greece & $\mathrm{RDC}$ & Mixed & 145 & 44.2 & 1.2 & 119 & 41.7 & 14.2 & & & & & & \\
\hline Gaudiano et al. 2009 & USA & DSM-IV & Mixed & 60 & 20.7 & 12.1 & 1052 & 26.1 & 13.8 & & & & & & \\
\hline Goldstein et al. 1998 & USA & $\mathrm{RDC}$ & Mixed & 25 & 26.9 & 8.4 & 93 & 28.4 & 9.4 & & & & & & \\
\hline Gournellis et al. 2001 & Greece & DSM-IV & Consecutive & 45 & 58.3 & 15.2 & 73 & 51.8 & 17.2 & & & & & & \\
\hline Hori et al. 1993 & Japan & DSM-III-R & Mixed & 38 & 48.3 & 15.1 & 55 & 41.7 & 14.3 & & & & & & \\
\hline Jäger et al. 2005 & Germany & DSM-IV & Mixed & 20 & 39.2 & 14.7 & 33 & 47.1 & 11.8 & 64 & 28.7 & 10.8 & & & \\
\hline Leyton et al. 1995 & Canada & DSM-III-R & Mlxed & 25 & 38.4 & 2.3 & 140 & 39.4 & 13.0 & & & & & & \\
\hline Maj et al. 1990 & Italy & DSM-III & Mixed & 36 & 32.0 & 3.0 & 36 & 31.8 & 3.5 & & & & & & \\
\hline Maj et al. 2007 & Italy & DSM-III & Mixed & 89 & 33.6 & 6.4 & 240 & 32.5 & 5.8 & & & & & & \\
\hline $\begin{array}{l}\text { Meyers \& } \\
\text { Greenberg, } 1986\end{array}$ & USA & DSM-III & Mixed & 72 & 62.4 & 15.5 & 89 & 51.5 & 17.2 & & & & & & \\
\hline Meyers et al. 1999 & USA & DSM-III-R & Mixed & 15 & 67.5 & 16.2 & 20 & 58.0 & 19.1 & & & & & & \\
\hline Park et al. 2014a & $\begin{array}{l}\text { South } \\
\text { Korea }\end{array}$ & DSM-IV & Mixed & 53 & 28.6 & 14.1 & 441 & 38.3 & 16.2 & & & & & & \\
\hline Parker et al. 1991 & Australia & $\begin{array}{l}\text { DSM-III. } \\
\text { RDC }\end{array}$ & Mixed & 35 & 48.1 & 16.5 & 101 & 36.2 & 15.5 & & & & & & \\
\hline Simpson et al. 1999 & UK & DSM-III-R & Mixed & 18 & 63.0 & 14.1 & 81 & 63.1 & 11.0 & & & & & & \\
\hline
\end{tabular}


Supplement Table 4. Studies on sociodemographic and risk factors in psychotic depression and comparison groups.

\begin{tabular}{|c|c|c|c|c|c|c|}
\hline $\begin{array}{l}\text { Reference } \\
\text { (city, country) }\end{array}$ & $\begin{array}{l}\text { Diagnosis } \\
\text { (setting) }\end{array}$ & $\begin{array}{l}\text { Sample size } \\
\text { (males/females) }\end{array}$ & $\begin{array}{l}\text { Comparison } \\
\text { groups }\end{array}$ & $\begin{array}{l}\text { Age of the } \\
\text { PD sample, } \\
\text { mean (SD) }\end{array}$ & $\begin{array}{l}\text { Sociodemographic } \\
\text { or risk factors }\end{array}$ & Main results and comments \\
\hline $\begin{array}{l}\text { Baldwin, } 1995 \\
\text { (Manchester, } \\
\text { UK) }\end{array}$ & $\begin{array}{l}\text { DSM-III-R } \\
\text { (mood- } \\
\text { incongruent } \\
\text { delusional } \\
\text { depression) } \\
\text { (Not reported) }\end{array}$ & $34(16 / 18)$ & $\operatorname{NPD}(n=100)$ & $\begin{array}{l}\text { median } 75.5 \\
\text { [range 65-89] }\end{array}$ & marital status & $\begin{array}{l}\text { Elderly sample. Individuals with PD } \\
\text { were more often single }(44 \%) \text { than } \\
\text { those with NPD }(12 \%)(p=0.04) \text {. }\end{array}$ \\
\hline $\begin{array}{l}\text { Breslau \& } \\
\text { Meltzer, } 1988 \\
\text { (Chicago, USA) }\end{array}$ & $\operatorname{RDC}(\mathrm{I})$ & $39(14 / 25)$ & $\begin{array}{l}\operatorname{PBD}(n=38), \\
\operatorname{SZAFF}(n=34)\end{array}$ & $37.1(13.2)$ & education, ethnicity & $\begin{array}{l}\text { Those with PBD had more years of } \\
\text { education (mean 13.3, SD 2.3) than } \\
\text { those with PD (mean 11.6, SD 3.2) } \\
\text { and SZAFF (mean 11.3, SD 2.8) } \\
\text { ( } p<0.005 \text { ). No difference in } \\
\text { percentage of white ( } 69 \% \text { in PD, } 61 \% \\
\text { in PBD and } 62 \% \text { in SZAFF). }\end{array}$ \\
\hline $\begin{array}{l}\text { Buoli et al. } \\
2013 \text { (Milan, } \\
\text { Italy) }\end{array}$ & DSM-IV-TR (I) & $18(3 / 15)$ & $\begin{array}{l}\text { NPD }(n=18 \\
\text { matched for } \\
\text { sample size })\end{array}$ & $59.7(17.0)$ & $\begin{array}{l}\text { family history for } \\
\text { major psychoses }\end{array}$ & $\begin{array}{l}\text { PD patients had more often family } \\
\text { history for major psychoses than } \\
\text { those with NPD ( } 6 \% \text { vs. } 39 \% \text {, } \\
p=0.016 \text { ). }\end{array}$ \\
\hline $\begin{array}{l}\text { Coryell \& } \\
\text { Tsuang, } 1982 \\
\text { (lowa City, } \\
\text { USA) }\end{array}$ & $\begin{array}{l}\text { Feighner } \\
\text { (delusional } \\
\text { depression) (I) }\end{array}$ & $122(57 / 65)$ & $\begin{array}{l}\text { nondelusional } \\
\text { depression (122) }\end{array}$ & $\begin{array}{l}43.8(\text { Not } \\
\text { reported) }\end{array}$ & marital status & $\begin{array}{l}\text { lowa } 500 \text { study. } 16 \% \text { of PD patients } \\
\text { and } 20 \% \text { of the NPD patients had } \\
\text { never been married. Difference in } \\
\text { proportion was not significant. }\end{array}$ \\
\hline $\begin{array}{l}\text { Coryell \& } \\
\text { Zimmerman, } \\
1988 \text { (lowa } \\
\text { City, USA) }\end{array}$ & $\operatorname{RDC}(\mathrm{I})$ & $29(11 / 18)$ & $\begin{array}{l}S Z(n=21), \text { SZAFF } \\
(n=47), H C(n=38)\end{array}$ & $42.8(16.3)$ & marital status & $\begin{array}{l}\text { Family study. Percentage of ever } \\
\text { married was } 66 \% \text { in PD, } 24 \% \text { in SZ, } \\
55 \% \text { in SZAFF, and } 63 \% \text { among } \\
\text { controls, differences in percentages } \\
\text { were non-significant. }\end{array}$ \\
\hline $\begin{array}{l}\text { Coryell et al. } \\
\text { 1984b (lowa } \\
\text { City, USA) }\end{array}$ & DSM-III (I) & $55(16 / 39)$ & NPD $(n=180)$ & $40.9(16.0)$ & marital status & $\begin{array}{l}\text { Individuals with PD were non- } \\
\text { significantly more common single } \\
(28 \%) \text { than those with NPD (21\%). }\end{array}$ \\
\hline $\begin{array}{l}\text { Coryell et al. } \\
1985 \text { (five } \\
\text { centers, USA) }\end{array}$ & DSM-III (I) & $76(24 / 52)$ & NPD $(n=473)$ & $39.0(16.0)$ & marital status & $\begin{array}{l}\text { Individuals with PD were non- } \\
\text { significantly more common single } \\
(36 \%) \text { than those with NPD ( } 29 \%) \text {. } \\
\text { Studied separately mood-congruent } \\
\text { and mood-incongruent PD (here we } \\
\text { have combined those). }\end{array}$ \\
\hline
\end{tabular}




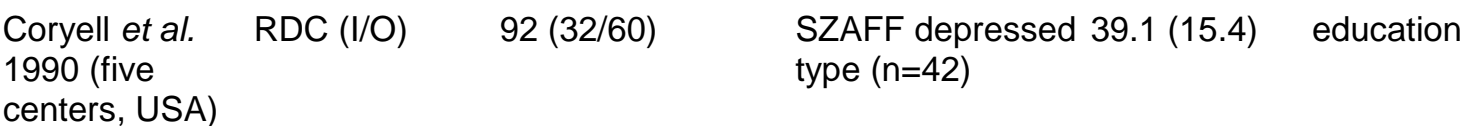

centers, USA)

\section{Craig et al.} 2000 [Craig et

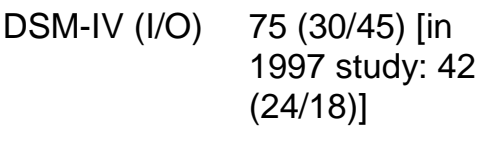
1997 study: 42

$$
(24 / 18)]
$$

al. 1997]

(Suffolk

County, USA)
SZ/SZAFF $(\mathrm{n}=15528.0$ (9.3) $[n=96])$, PBD

$(n=119[n=64])$ ethnicity, marital status, social class, [education]

\section{Čulav-Sumić \& ICD-10 \\ Jukić, 2010 recurrent PD \\ (Zagreb, \\ (I)}

Croatia)

Dell'Osso et al. DSM-III-R (I) 2002 (Pisa

Italy)

\section{$50(0 / 50)$}

$30(10 / 20)$

PBD ( $\mathrm{n}=147$; most 36.2 (12.7) recent episode:

pure mania, $\mathrm{n}=55$;

mixed mania

$\mathrm{n}=62$; depressed,

$\mathrm{n}=30$ )

$(\mathrm{n}=50), \mathrm{HC}(\mathrm{n}=50$

hospital personal)

$55.3(10.2)$

minor physical

anomalies (51

different anomalies, also total sum score)

education, marital status

NPD (148)

Draper \&

DSM-III, DSM- 47 (Not reported) Anstey, 1996 III-R, ICD-9 (I)

(Sydney,

Australia) not reported psychosocial and for PD, mean medical stressors at age for the admission (eight total sample categories)
Studied separately those who completed the follow-up and those with only baseline data (here we have combined those groups). Individuals with PD had nonsignificantly $(p=0.20)$ higher level of education (mean 3.5, SD 1.5) than those with schizoaffective disorder (mean 3.2, SD 1.1).

Data based on Suffolk County Mental Health Project, epidemiological study of new admissions. Groups did not differ significantly regarding proportion of African American (PD $7 \%$, SZ/SZAFF 22\%, PBD 6\%); never married (55\%, 79\%, 61\%; respectively); having high school education $(87 \%, 77 \%, 87 \%$;

respectively); or being from lower social class $(11 \%, 19 \%, 13 \%$, respectively). Fennig et al. (1996) have published similar results from the same study, with smaller sample. Sample included only women. Mean number of physical anomalies was

highest in PD (mean 2.9, SD 1.4).

Corresponding mean was 2.5 (SD

1.6) for NPD and 1.6 (SD 1.4) for HC. Difference between $\mathrm{PD}$ and $\mathrm{HC}$ was statistically significant $(p<0.001)$, but not between PD and NPD ( $p=0.36)$. $P D$ did not differ significantly from PBD on having graduate/undergraduate education ( $57 \%$ vs. $54 \%$ ) or in being unmarried (67\% vs. $76 \%$ ). Compared originally three PBD groups and PD, here PBD groups are pooled.

Elderly sample. Compared originally to three comparison groups, here major and minor depression are pooled to NPD, whereas organic 
74.1 years 1983 (Athens,

Greece)

Gaudiano et al. DSM-IV (O)

2009

[Gaudiano \&

Zimmerman,

2010] (Rhode

Island, USA)

Gaudiano et al. DSM-IV-TR 2016 (Rhode (I/O)

Island, USA)
$145(43 / 102) \quad$ NPD $(n=119)$

$60(16 / 44)[32$

$(10 / 22)]$

NPD $(n=1052$

[591])

(1)

$174(74 / 100)$

NPD $(n=1140)$

$44.9(12.3)$

$37.0(11.7)$

$[36.8(13.1)]$

[childhood trauma] depression has been excluded.

Acute medical problems were less common in PD (30\%) than in NPD $(51 \%)(p=0.012)$. No differences in psychosocial stressors.

Groups did not differ by family history mental illness and for (mental illness: PD 32\%, NPD 30\%; affective disorders affective disorders: PD 19\%, NPD $17 \%)$.

education, ethnicity, PD patients were less often

Caucasian than those with NPD

( $65 \%$ vs $86 \%, p<0.001)$. PD patients were also less often college

graduates $(13 \%$ vs. $34 \%, p=0.001)$. The difference between groups was not significant in amount of single patients (PD 22\%, NPD 27\%). Individuals with PD are more likely to have physical or sexual trauma than those with NPD (84\% vs. $64 \%$, $\mathrm{p}=0.017)$. Gaudiano et al. (2008) studied an overlapping sample.

ethnicity, race, $\quad$ PD patients were less often white marital status, history ( $79 \%$ vs. $89 \%$; $p<0.001)$, more often of physical, sexual or Latino or Hispanic ( $26 \%$ vs. $6 \%$, emotional abuse

$\mathrm{p}<0.001)$, and less often married or with domestic partner (26\% vs. $35 \%$, $\mathrm{p}=0.017)$. There were no differences in history of abuse (PD 65\% vs. NPD $58 \%, p=0.18)$.

21.9 (4.2) education, marital [23.3 (3.4] (Not reported)]

NPD $(n=95$

$[\mathrm{n}=70])$

status, ethnicity [premorbid social adjustment scale (SADS), ZiglerPhillips Social

Competence Scale, Phillips Scale of

Premorbid

Adjustment (also subscales)]
Chicago Follow-up study. Individuals with PD were non-significantly less often Caucasian $(67 \%$ vs. $83 \%$; $\mathrm{p}=0.06)$ or married $(11 \%$ vs. $20 \%$; $p=0.29$ ) than those with NPD. Average years of education was 13.0 (SD 1.5) in PD and 13.8 (2.1) years in NPD $(p=0.03)$. PD group had more patients with poor social adjustment score in SADS $(47 \%$ vs. $15 \%$, $\mathrm{p}=0.03$ ) and with poor social competence score $(23 \%$ vs. $13 \%$, 
Gournellis et al. DSM-IV (I) 2001 (Athens,

Greece)

\section{Heslin et al. \\ 2016 \\ (Nottingham \\ and London,}

UK)
$45(14 / 31)$

NPD $(n=73)$

$69.6(5.8)$

(a)

education, marital

status, family history

of unipolar

depression

ICD-10 (I/O) $72(36 / 36)$
$S Z(n=218)$, PBD
$(n=70), H C$ $(n=391)$ range 25-41)

$\mathrm{p}=0.01$ ). Groups did not differ significantly regarding proportion of poor premorbid adjustment in Phillips Scale (30\% vs. $21 \%)$. Study included also a group of patients with any bipolar disorder (not shown here).

PD and NPD group did not differ

significantly regarding mean years of education (6.0 vs. 5.3), proportion of married (44\% vs. $62 \%$ ) or proportion of those with first degree relatives with unipolar depression (20\% vs. 22\%).

education, ethnicity, First episode (incidence) study
place of birth (UK vs. investigating several risk factors.

non-UK), current and Individuals with PD were statistically lifetime relationship significantly more often living alone status, living alone, (OR 2.26), had basic level education employment, contact (OR 2.89), were unemployed (OR with friends, contact 2.12), had less than monthly contact with family, close confidants, severe with friends (OR 4.24), no close confidants (OR 4.71), childhood life events, childhood adversity (OR 2.57), neurological soft adversity, family history of psychosis or any mental illness signs (OR 1.15), and family history of neurological soft any mental illness (OR 10.68) or signs, minor physica signs, minor phy
abnormalities

psychosis (OR 12.85) when compared with controls. The study

presented also ORs for SZ and PBD when compared to controls, the $95 \%$ confidence intervals did not overlap between SZ and PD in current relationship status were PD patients were less often single.

Hill et al. 2004 DSM-III-R,

$20(9 / 11)$

SZ/SZAFF ( $n=86), 25.2$ (8.8)tot education, ethnicity, $\mathrm{HC}(\mathrm{n}=81)$

own socioeconomic status (SES,

Hollingshead Index of Social Position), parental SES

PD did not differ from other groups in mean years of education (PD 13.4, SZ/SZAFF 13.4, HC 14.5), in

USA) DSM-IV (I) proportion of Caucasian (PD 65\%, SZ/SZAFF 55\%, HC 63\%) or in own (mean scores: PD 2.9, SZ/SZAFF 3.3, HC 2.8) or parental SES (PD 2.7, SZ/SZAFF 2.9, HC 2.8). NPD group was small $(n=14)$ and was not included here.

Ihezue, 1985 ICD-9 (I)

NPD ( $n=64)$

$\sim 39$ years

education, marital
First episode study. PD patients were 
(Enugu,

Nigeria)

Jarbin et al. DSM-IV (I) $17(8 / 9)$
2003 (Lund,
Sweden)

Sweden)

Johnson et al. DSM-III (I/O)
1991 (New
Haven, St.
Louis,
Baltimore,
Durham, and
Los Angeles,
USA)
Karaaslan et al. DSM-IV (I)
2003 (Turkey)
Lee et al. 2003 DSM-IV (I)
(Taipei,
Taiwan)

status, urban/rural more often (62\%) from rural domicile domicile, occupation than patients with NPD (16\%)

$(p<0.001)$. Proportion of single patients was $32 \%$ in PD and $53 \%$ in NPD $(p=0.011)$. Regarding

education, proportion of illiterate was $38 \%$ in PD and $13 \%$ in NPD

$(p=0.001)$. Amount of unskilled workers was $50 \%$ in PD and $34 \%$ in NPD $(p=0.06)$.

$\mathrm{SZ}(\mathrm{n}=32)$, PBD median 16.2 heredity of bipolar $(n=25)$

\section{[range 13.4-} 17.7] and non-mood disorders.
$16(8 / 8)$

delusional depression 48 $(15 / 33)$ [in family history $n=37]$ non-delusional depression (108) [in family history $\mathrm{n}=79$ ]
NPD $(n=20), H C \quad 36.5(8.7) \quad$ education $(\mathrm{n}=20)$

$74.7(6.1)$ ethnicity, marital

status, socioeconomic status $\mathrm{Pr}$ (SES)

education, family history of affective disorder
First episode study, adolescent onset sample. Proportion of those with bipolar disorder heredity was $6 \%$ in PD, $30 \%$ in PBD, and $9 \%$ in SZ.

Proportion of those with nonmood disorder heredity was $12 \%$ in PD, $17 \%$ in PBD, and $34 \%$ in SZ.

Differences were nonsignificant.

SZAFF group has been excluded here due to small $(n=7)$ sample size.

Community based Epidemiological Catchment Area (ECA) study.

Proportion of white was $61 \%$ in PD and $73 \%$ in NPD ( $p=0.005)$. Those with PD had lower SES than those with NPD (amount of those in lowest SES quartile was $21 \%$ in PD and $13 \%$ in NPD) ( $p=0.01)$. There were no differences in amount of married patients $(38 \%$ in PD and $37 \%$ in NPD).

Mean years of education was lower $(p<0.05)$ in PD (8.8; SD 1.16 years) than in NPD $(10.4 ; 0.8)$ and in HC (10.02; 1.05).

Mean years of education was 7.18 (SD 5.1) in delusional depression and 8.28 (4.9) in non-delusional depression. Proportion of those with family history of affective disorder was $(5 / 37 ; 14 \%)$ in delusional depression and $(8 / 79 ; 10 \%)$ in non- 
Maj et al. 1990 DSM-III (I/O) (Naples, Italy)

$36(15 / 21)$

NPD $(n=36)$

$42.0(6.3)$

history of affective

disorders and

schizophrenia

$89(34 / 55)$

NPD $(n=240)$

$45.2(8.9)$

family history of bipolar I disorder

\section{(Naples, Italy) (delusional \\ depression \\ (I/O)}

Nakamura et ICD-10 (I)

al. 2015

(Tokushima,

Japan)

Okulate et al. 2001 (Lagos,

Nigeria)

ICD-10 (I/O) $31(19 / 12)$

NPD $(n=56)$ for PD, mean psychiatric disease age for the

total sample

$\sim 62$ years

not reported marital status,

for PD, mean religion, education, age for the family history of not reported family history of any

total sample mental illness,

33.2 (9.7) alcohol abuse,

years

suicide or attempted suicide; precipitating

factors of life events

$\begin{array}{lll}\begin{array}{l}\text { Østergaard et } \\ \text { al. } 2013 \mathrm{~b}\end{array} & \text { (I/O) } & \text { reported) } \\ \text { (whole } & & \\ \text { Denmark) } & & \\ & & \end{array}$

$\mathrm{HC}$ (population not reported history of mental sample of 2.4 Million) delusional depression. Differences were nonsignificant.

In PD 56\% and in NPD 53\% were married. Proportion of those with family history of affective disorders (PD 30\% vs. NPD 25\%) and schizophrenia (3\% in both) did not differ between groups. NPD sample was restricted to same sample size than PD.

Individuals with PD had more often family history of bipolar I disorder than those with NPD (16\% vs. $7 \%$, $\mathrm{p}=0.02$ ).

Groups did not differ by family history of any psychiatric disease (PD: $41 \%$, NPD: $46 \%$ ).

Hospital with $40 \%$ patients being

military personnel and $60 \%$ civilians.

No significant difference between PD and NPD in being married (48\% vs. $50 \%$ ), being Christian ( $81 \%$ vs. $71 \%$ ) or having secondary school or above education (68\% vs. $73 \%)$. PD

patients had more often family history of mental illness than those with NPD ( $45 \%$ vs. $15 \%, p<0.001$ ), whereas there was no difference in family history of alcohol abuse (13\% vs. $26 \%$ ), family history of suicide (3\% vs. $5 \%$ ) or in precipitating life events (52\% vs. $64 \%$ ). Study included also a group of patients with any bipolar disorder (not shown here).
Population-based historical prospective cohort study of all individuals born in Denmark between 1955 and 1990. Used in- and mother, father or siblings, place of birth, born in city of Aarhus, gestational outpatient data from Danish

Psychiatric Central Research 
age, birth weight,

\section{Park et al. \\ 2014a (18 \\ centers, South}

DSM-IV (I)

$53(17 / 36)$

Korea)

Parker et al.

DSM-III, RDC $35(12 / 23)$

1991 (Sydney, (I/O)

Australia)

$$
\text { NPD }(n=441)
$$

40.7 (15.2)

$\operatorname{NPD}(n=102)$

$62.5(12.1)$

NPD $(n=16), S Z \quad 49(15) \quad$ education

$(n=20), H C(n=20)$

2004 (Athens,

Greece)

Rush et al.

DSM-IV $(\mathrm{O})$

2006 (Austin,

USA) small for gestationa age, maternal and paternal age at bir loss of relative (mother, father or sibling; before and after age 15 years).

education, marita

status, religious

affiliation, family

history of depression

and other mental

disorders

family history of

depressive disorder, alcoholism

Register. Studied risk (incidence rate ratio, IRR) for PD (and also for NPD, data not shown here) in population

using several register variables.

Several maternal, paternal and sibling psychiatric diagnoses associated significantly with PD.

Highest IRR (2.2, 95\% CI 2.0-2.4; $\mathrm{p}<0.001$ ) was in maternal any mental disorder. Loss of mother because of an unnatural cause after age 15 years associated with PD (IRR 1.7, 1.2-2.3; $p=0.011)$. Other studied variables did not associate with PD.

Statistical tests are both unadjusted and adjusted with age and depression symptoms. Individuals with PD were had more education in years than those with NPD (12.2 vs. 10.3; $p=0.003$, adj. $p=0.06$ ).

Differences were non-significant in being married ( $67 \%$ vs. $78 \%$ ), having family history of depression (23\% vs.

$16 \%$ ) or of other mental disorders (6\% vs. $8 \%$ ), or in having religious affiliation (62\% vs. $65 \%)$.

PD did not differ significantly from

those with NPD regarding proportion of those with family history of depressive disorder (31\% vs. 39\%), schizophrenia ( $9 \%$ vs. $5 \%$ ) or alcoholism (11\% vs. $14 \%)$. Studied also separately age- and sexmarched subsample of NPD (data not shown).

Mean (SD) education in years was 10 (4) in PD, 11 (3) in NPD, 11 (3) in SZ, and 12 (3) in HC. Groups did not differ significantly.

education, ethnicity, Proportion of white was lower in PD marital status
$(38 \%)$ than in NPD $(55 \%)(p<0.001)$. Proportion of married $(27 \%$ in PD 
Simpson et al. DSM-III-R (I/O) 18 (7/11)

1999

(Manchester,

UK)

Thakur et al. DSM-III-R (I/O) 189 (62/127)

1999 (Durham,

NPD $(n=485)$

USA)

Zaninotto et al. DSM-IV (I/O) $90(25 / 65)$

2013

(multicenter:

Brussels,

Leuven, Milan,

Paris, Sint-

Truiden, Tel-

Hashomer,

Vienna)

NPD $(n=609)$ and $28 \%$ in NPD) and years of education (PD 11.1 (SD 2.6), NPD 11.2 (3.2)) did not differ between groups.

NPD ( $n=81) \quad 75.2(4.6) \quad$ education, premorbid Elderly population. PD and NPD did $I Q$, family history of not differ by mean years of education depression

10.0 vs. 10.3), premorbid IQ (104.4 vs. 111.1) or by family history of depression (37\% vs. 60\%).

Family history of suicide was present $\begin{array}{ll}(50 \% \text { was } 60 \text { suicide } & \text { in } 32 \% \text { among PD and in } 24 \% \\ \text { years or } & \text { among NPD patients }(\mathrm{p}=0.04)\end{array}$ years or more)

$48.8(14.6)$

education, ethnicity, Proportion of single patients was marital status, family $12 \%$ in PD and $15 \%$ in NPD, PD history of major group had $75 \%$ and NPD group $63 \%$ depressive disorder, with secondary or higher education. bipolar disorder and suicide
Proportion of white was $97 \%$ in both PD and NPD. Regarding family history, proportion of depression was $62 \%$ in PD and $49 \%$ in NPD, of bipolar disorder $5 \%$ in $\mathrm{PD}$ and $7 \%$ in NPD, and of suicide $18 \%$ in PD and $15 \%$ in NPD. All differences were nonsignificant. NPD sample was originally in two groups (melancholic and non-melancholic).

Abbreviations: ICD: International Classification of Diseases; ICD-10-AM = ICD-10 Australian Modification; DSM: Diagnostic and Statistical Manual o Mental disorders; Odds Ratio = OR; RDC = Research Diagnostic Criteria; $S D=$ standard deviation, $S E S=$ socioeconomic status.

Diagnoses: PD = psychotic depression, NPD = nonpsychotic depression, PBD = psychotic bipolar disorder, SZ = schizophrenia, SZAFF = schizoaffective disorder, $\mathrm{HC}=$ healthy controls.

Settings: I = inpatients, $\mathrm{O}=$ outpatients, $\mathrm{I} / \mathrm{O}=$ both in- and outpatients 
Supplement Table 5. Studies comparing the outcome of psychotic depression to other disorders. For the results see also the Supplement Figures.

\begin{tabular}{|c|c|c|c|c|c|c|c|c|}
\hline $\begin{array}{l}\text { Reference } \\
\text { (country) }\end{array}$ & $\begin{array}{l}\text { Time of } \\
\text { data } \\
\text { collection } \\
\text { City }\end{array}$ & $\begin{array}{l}\text { Diagnosis } \\
\text { Setting } \\
\text { (I/O) } \\
\text { Study } \\
\text { design }\end{array}$ & $\begin{array}{l}\text { Sample } \\
\text { size of PD } \\
\text { (males/fem } \\
\text { ales) }\end{array}$ & $\begin{array}{l}\text { Comparison } \\
\text { groups }\end{array}$ & $\begin{array}{l}\text { Onset age, } \\
\text { mean (SD) } \\
\text { Mean age at } \\
\text { study } \\
\text { moment (SD) }\end{array}$ & $\begin{array}{l}\text { Retrospe } \\
\text { ctive/pro } \\
\text { spective } \\
\text { Follow- } \\
\text { up time, } \\
\text { mean } \\
\text { (SD) }\end{array}$ & $\begin{array}{l}\text { Outcome } \\
\text { measures }\end{array}$ & Main results and comments \\
\hline
\end{tabular}

\section{First-episode samples}

\begin{tabular}{|c|c|c|c|c|c|c|c|c|}
\hline $\begin{array}{l}\text { Baldwin, } \\
1988 \text { (UK) }\end{array}$ & $\begin{array}{l}1976- \\
1981 \\
\text { Manchest } \\
\text { er }\end{array}$ & $\begin{array}{l}\text { Feighner } \\
\text { (delusional } \\
\text { depression) } \\
\text { (I) } \\
\text { First- } \\
\text { episode }\end{array}$ & $24(4 / 20)$ & $\begin{array}{l}\text { non-delusional } \\
\text { depression } \\
\text { (n=24 matched } \\
\text { by age, sex } \\
\text { and follow-up } \\
\text { length) }\end{array}$ & $\begin{array}{l}\text { Not reported } \\
74.2 \text { [range } \\
65-88 \text { ] years }\end{array}$ & $\begin{array}{l}\text { Retrospec } \\
\text { tive } \\
61-\text { month } \\
\text { follow-up } \\
\text { [range 42- } \\
104 \text { ] }\end{array}$ & $\begin{array}{l}\text { Depressive } \\
\text { symptoms } \\
\text { (HAMD), } \\
\text { course of } \\
\text { depression } \\
\text { symptoms } \\
\text { Relapses } \\
\text { requiring } \\
\text { hospitalisatio } \\
n\end{array}$ & $\begin{array}{l}\text { Included in meta-analysis: } \\
\text { Poor global clinical outcome (course of } \\
\text { depression symptoms): } \\
\text { Depressive invalidism: } 21 \% \text { vs. } 33 \% \\
\text { Ill with depression throughout: } 4 \% \text { vs. } 4 \% \\
\text { Not included in meta-analysis: } \\
\text { Relapse rate: at } 12 \text { months: } 13 \% \text { vs. } 13 \% \text {; } \\
\text { at } 24 \text { months: } 33 \% \text { vs. } 17 \% \text {; at } 36 \text { months: } \\
33 \% \text { vs. } 21 \% \text {; at } 48 \text { months: } 46 \% \text { vs. } 25 \% \\
\text { Comment: } \\
\text { Only cases older than } 65 \text { years included. } \\
\text { See also Baldwin } 1995 \text { with partly } \\
\text { overlapping sample (the results not } \\
\text { presented here). }\end{array}$ \\
\hline $\begin{array}{l}\text { Breslau \& } \\
\text { Meltzer, } 1988 \\
\text { (USA) }\end{array}$ & $\begin{array}{l}\text { Not } \\
\text { reported } \\
\text { Chicago }\end{array}$ & $\begin{array}{l}\text { RDC } \\
\text { (I) } \\
\text { First- } \\
\text { episode }\end{array}$ & 25) & $\begin{array}{l}\operatorname{PBD}(n=38), \\
\operatorname{SZAFF}(n=34)\end{array}$ & $\begin{array}{l}26.3(11.2) \\
37.1(13.2)\end{array}$ & $\begin{array}{l}\text { Cross- } \\
\text { sectional } \\
\text { No follow- } \\
\text { up }\end{array}$ & $\begin{array}{l}\text { Depressive } \\
\text { symptoms } \\
\text { (SADS-C) }\end{array}$ & $\begin{array}{l}\text { Included in meta-analysis: } \\
\text { For depressive symptoms see Supplement } \\
\text { Figures } 2 a \text { and } 3 a \text {. }\end{array}$ \\
\hline $\begin{array}{l}\text { Craig et al. } \\
2000 \text { (USA) } \\
\text { (Fennig et al. } \\
\text { 1996; Craig } \\
\text { et al. 1997) }\end{array}$ & $\begin{array}{l}1989- \\
1995 \\
\text { The } \\
\text { Suffolk } \\
\text { County } \\
\text { Psychosis } \\
\text { Project }\end{array}$ & $\begin{array}{l}\text { DSM-IV) } \\
(\mathrm{I} / \mathrm{O}) \\
\text { First- } \\
\text { episode }\end{array}$ & $75(30 / 45)$ & $\begin{array}{l}\text { SZ/SZAFF } \\
(n=155), \text { PBD } \\
(n=119)\end{array}$ & $\begin{array}{l}\text { Not reported } \\
\text { At admission } \\
31 \text { (SD not } \\
\text { reported) }\end{array}$ & $\begin{array}{l}\text { Prospectiv } \\
\text { e } \\
\text { 24-month } \\
\text { follow-up }\end{array}$ & $\begin{array}{l}\text { Rehospitaliza } \\
\text { tions, } \\
\text { remission, } \\
\text { global } \\
\text { outcome } \\
\text { (GAF), and } \\
\text { symptoms } \\
\text { (SANS, } \\
\text { SAPS, }\end{array}$ & $\begin{array}{l}\text { Included in meta-analysis: } \\
\text { For symptoms and global outcome see } \\
\text { Supplement Figures } 2 a, c, d, e \text { and } 3 a-c . \\
\text { Not included in meta-analysis: } \\
\text { Rehospitalization: PD } 29 \% \text { vs. SZ/SZAFF } \\
54 \% \text { vs. PBD 33\% } \\
\text { Full remission: PD } 60 \% \text { vs. SZ/SZAFF 14\% } \\
\text { vs. PBD } 78 \%\end{array}$ \\
\hline
\end{tabular}




\begin{tabular}{|c|c|c|c|c|c|c|c|c|}
\hline & & & & & & & $\begin{array}{l}\text { BPRS, } \\
\text { HAMD) }\end{array}$ & $\begin{array}{l}\text { Partial or no remission: PD 33\%, SZ/SZAFF } \\
31 \% \text {, PBD } 19 \%\end{array}$ \\
\hline $\begin{array}{l}\text { Hill et al. } \\
2004 \text { (USA) }\end{array}$ & $\begin{array}{l}\text { Not } \\
\text { reported } \\
\text { Pittsburgh }\end{array}$ & $\begin{array}{l}\text { DSM-III-R } \\
\text { or DSM-IV } \\
\text { (I) } \\
\text { First- } \\
\text { episode }\end{array}$ & $20(9 / 11)$ & $S Z(n=86)$ & $\begin{array}{l}25.20(8.84) \\
\text { Not reported }\end{array}$ & $\begin{array}{l}\text { Prospectiv } \\
\text { e } \\
\text { 2-year } \\
\text { follow-up }\end{array}$ & $\begin{array}{l}\text { Symptoms } \\
\text { (HAMD, } \\
\text { BPRS, } \\
\text { SAPS, } \\
\text { SANS) } \\
\text { global } \\
\text { outcome } \\
\text { (GAF) }\end{array}$ & $\begin{array}{l}\text { Included in meta-analysis: } \\
\text { See Supplement Figures 2a-e for symptoms } \\
\text { and GAF. } \\
\text { Comment: } \\
\text { All study groups were matched } \\
\text { demographically on age, sex, and parental } \\
\text { socioeconomic status. NPD comparison } \\
\text { group not included here due to small } \\
\text { sample size. }\end{array}$ \\
\hline $\begin{array}{l}\text { Husted et al. } \\
1995 \\
\text { (Canada) }\end{array}$ & $\begin{array}{l}1982- \\
1984 \\
\text { Vancouve } \\
r \text { (part of } \\
\text { the } \\
\text { Markers } \\
\text { and } \\
\text { Predictors } \\
\text { Study } \\
\text { (MAP)) }\end{array}$ & $\begin{array}{l}\text { DSM-III } \\
(\mathrm{I} / \mathrm{O}) \\
\text { First- } \\
\text { episode }\end{array}$ & $\begin{array}{l}25(16 / 9) \\
\text { (at follow- } \\
\text { up) }\end{array}$ & $\begin{array}{l}\text { PBD }(n=27) \\
\text { SZ }(n=66)\end{array}$ & $\begin{array}{l}26.3(8.09) \\
\text { Not reported }\end{array}$ & $\begin{array}{l}\text { Prospectiv } \\
\text { e } \\
\text { 18-month } \\
\text { follow-up }\end{array}$ & $\begin{array}{l}\text { Number of } \\
\text { negative } \\
\text { symptoms } \\
\text { (not severity) } \\
\text { based on } \\
\text { DSM. }\end{array}$ & $\begin{array}{l}\text { Included in meta-analysis: } \\
\text { See Online Supplement figure } 2 d \text { for mean } \\
\text { number of negative symptoms. }\end{array}$ \\
\hline $\begin{array}{l}\text { Jarbin et al. } \\
2003 \\
\text { (Sweden) }\end{array}$ & $\begin{array}{l}1982- \\
1993 \\
\text { Lund }\end{array}$ & $\begin{array}{l}\text { DSM-IV } \\
\text { (I) } \\
\text { First- } \\
\text { episode }\end{array}$ & $17(8 / 9)$ & $\begin{array}{l}\text { SZ }(n=32) \\
\text { PBD }(n=25)\end{array}$ & $\begin{array}{l}\text { Median } 16.2 \\
\text { (range 13.4- } \\
17.7 \text { ) } \\
\text { Not reported }\end{array}$ & $\begin{array}{l}\text { Prospectiv } \\
\text { e } \\
\text { 10.5-year } \\
\text { follow-up } \\
\text { (range } \\
5.1-18.2 \text { ) } \\
\text { after } \\
\text { admission }\end{array}$ & $\begin{array}{l}\text { GAF and } \\
\text { employment } \\
\text { combined to } \\
\text { global } \\
\text { outcome, } \\
\text { symptoms }\end{array}$ & $\begin{array}{l}\text { Not included in meta-analysis: } \\
\text { Good outcome: PD 71\%, SZ 6\%, PBD 40\%. } \\
\text { Intermediate outcome: PD 18\%, SZ 16\%, } \\
\text { PBD } 24 \% \text {. } \\
\text { Poor outcome: PD 6\%, SZ 12\%, PBD 16\%. } \\
\text { Very poor outcome: PD 6\%, SZ 66\%, PBD } \\
\text { 16\%. } \\
\text { Disability pension: PD 29\%, SZ 88\%, PBD } \\
33 \% \text {. } \\
\text { No employment: PD 7\%, SZ 52\%, PBD } \\
14 \% \text {. } \\
\text { Serious symptom severity: PD 7\%, SZ 48\%, } \\
\text { PBD 15\%. } \\
\text { None symptoms: PD } 87 \%, \text { SZ 32\%, PBD } \\
6 \% \text {. } \\
\text { Mean GAF score (no SD given): PD } 81 \text {, }\end{array}$ \\
\hline
\end{tabular}


PBD 66, SZ 34.

Comment:

Adolescent onset psychoses, first episode sample. Diagnoses based on initial

diagnosis at onset, SZAFF group not shown here due to small sample size.

\begin{tabular}{|c|c|c|c|c|c|c|c|c|}
\hline $\begin{array}{l}\text { Opjordsmoen } \\
1991 \\
\text { (Norway) }\end{array}$ & $\begin{array}{l}1946- \\
1948 \\
\text { (long-term } \\
\text { group) } \\
\text { and 1958- } \\
1961 \\
\text { (short- } \\
\text { term } \\
\text { group) } \\
\text { Oslo }\end{array}$ & $\begin{array}{l}\text { DSM-III } \\
\text { (I) } \\
\text { First- } \\
\text { episode }\end{array}$ & $50(20 / 30)$ & $\begin{array}{l}\text { SZAFF } \\
\text { depressed } \\
\text { type }(n=33)\end{array}$ & $\begin{array}{l}\text { Not reported } \\
40.8 \text { (SD not } \\
\text { reported) }\end{array}$ & $\begin{array}{l}\text { Prospectiv } \\
\text { e } \\
\text { mean } \\
22.3 \\
\text { (range 3- } \\
39 \text { ) }\end{array}$ & $\begin{array}{l}\text { Global } \\
\text { outcome } \\
\text { (GAS) } \\
\text { Employment } \\
\text { Recovery } \\
\text { Number of } \\
\text { episodes }\end{array}$ & $\begin{array}{l}\text { Not included in meta-analysis: } \\
\text { Mean GAS score: PD } 3.8 \text { vs. SZAFF } 3.4 \text {. } \\
\text { Employed: PD } 69 \% \text { vs. SZAFF } 46 \% \\
\text { Recovery: PD } 66 \% \text { vs. SZAFF } 42 \% \\
\text { Only index episode: PD } 46 \% \text { vs. SZAFF } \\
27 \% \\
\text { Mean number of episodes at follow-up: PD } \\
3.1 \text { vs. SZAFF } 3.3 \\
\text { First admissions study. }\end{array}$ \\
\hline $\begin{array}{l}\text { Owoeye et al. } \\
2013 \text { (Ireland) }\end{array}$ & $\begin{array}{l}1995- \\
2008 \\
\text { Cavan- } \\
\text { Monaghan } \\
\text { (CAMFEP } \\
\text { S study) }\end{array}$ & $\begin{array}{l}\text { DSM-IV } \\
\text { (I/O) } \\
\text { First- } \\
\text { episode }\end{array}$ & $77(36 / 41)$ & $\begin{array}{l}\text { PBD }(n=54), \\
\text { SZ }(n=73)\end{array}$ & $\begin{array}{l}51.2(22.0) \\
\text { Not reported }\end{array}$ & $\begin{array}{l}\text { Prospectiv } \\
\text { e } \\
6 \text {-month } \\
\text { follow-up }\end{array}$ & $\begin{array}{l}\text { Positive and } \\
\text { negative } \\
\text { symptoms } \\
\text { (PANSS) }\end{array}$ & $\begin{array}{l}\text { Included in meta-analysis: } \\
\text { See Supplement Figure } 2 c, d \text { and } 3 b, c \text { for } \\
\text { positive and negative symptoms. }\end{array}$ \\
\hline $\begin{array}{l}\text { Taiminen et } \\
\text { al. 2000 } \\
\text { (Finland) }\end{array}$ & $\begin{array}{l}1994- \\
1998 \\
\text { Turku }\end{array}$ & $\begin{array}{l}\text { DSM-IV } \\
(\mathrm{I} / \mathrm{O}) \\
\text { First- } \\
\text { episode }\end{array}$ & $23(10 / 13)$ & $\begin{array}{l}\text { NPD }(n=25), \\
\text { SZ }(n=17), H C \\
(n=19)\end{array}$ & $\begin{array}{l}\text { Not reported } \\
33.3(9.4)\end{array}$ & $\begin{array}{l}\text { Cross- } \\
\text { sectional }\end{array}$ & $\begin{array}{l}\text { Symptoms } \\
\text { (BPRS, } \\
\text { HAMD) }\end{array}$ & $\begin{array}{l}\text { Included in meta-analysis: } \\
\text { See Supplement Figures } 1 \mathrm{a}, \mathrm{b} \text { and } 2 \mathrm{~b} \text { for } \\
\text { symptoms. }\end{array}$ \\
\hline $\begin{array}{l}\text { Tohen et al. } \\
2000 \text { (USA) }\end{array}$ & $\begin{array}{l}1989- \\
1995 \\
\text { Boston } \\
\text { (McLean- } \\
\text { Harvard } \\
\text { study) }\end{array}$ & $\begin{array}{l}\text { DSM-IV } \\
\text { (I) } \\
\text { First- } \\
\text { episode }\end{array}$ & $\begin{array}{l}44 \text { (Not } \\
\text { reported) }\end{array}$ & $\begin{array}{l}\text { PBD }(n=128), \\
\text { SZAFF }(n=20)\end{array}$ & $\begin{array}{l}\text { Not reported } \\
\text { Age at } \\
\text { admission for } \\
\text { the whole } \\
\text { study group } \\
31.9(5.0)\end{array}$ & $\begin{array}{l}\text { Prospectiv } \\
\text { e } \\
6 \text {-month } \\
\text { follow-up }\end{array}$ & $\begin{array}{l}\text { Syndromal } \\
\text { recovery (i.e. } \\
\text { remission) } \\
\text { Functional } \\
\text { recovery }\end{array}$ & $\begin{array}{l}\text { Included in meta-analysis: } \\
\text { Syndromal recovery (i.e. remission): PD } \\
75 \% \text { vs. PBD } 39 \% \text {, see Online Supplement } \\
\text { figure } 1 \text { d. } \\
\text { Not included in meta-analysis: } \\
\text { Functional recovery: PD 32\%, PBD 37\%, } \\
\text { SZAFF 0 } \\
\text { Syndromal recovery (i.e. remission): PD } \\
75 \% \text { vs. SZAFF 70\% } \\
\text { Comment: } \\
\text { See also Tohen et al. (1992) for partly }\end{array}$ \\
\hline
\end{tabular}


overlapping sample (results not presented here)

\section{Consecutive or mixed samples}

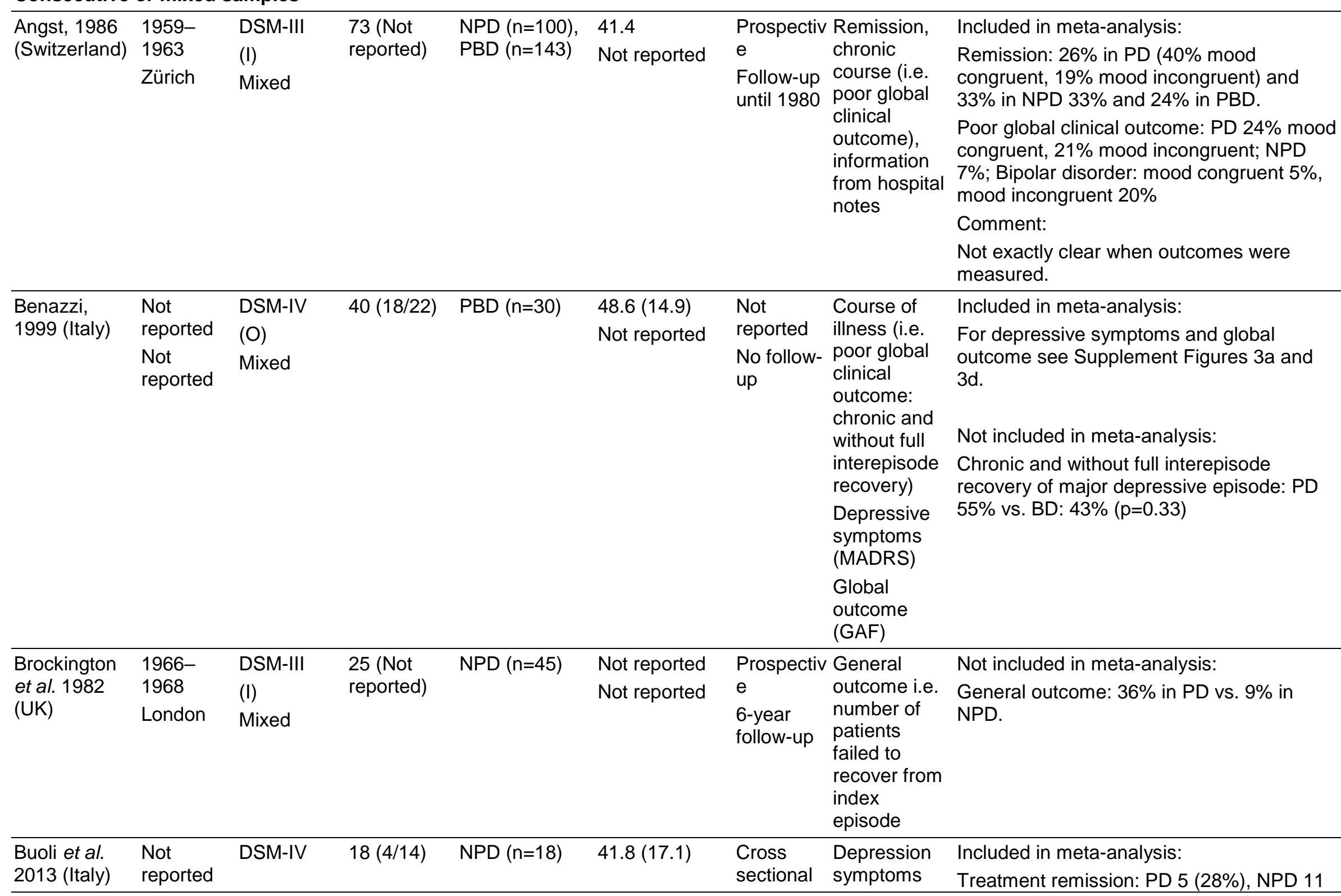




\begin{tabular}{|c|c|c|c|c|c|c|c|c|}
\hline & Milan & $\begin{array}{l}\text { (I) } \\
\text { Mixed }\end{array}$ & & & $59.7(17.0)$ & $\begin{array}{l}\text { 8-week } \\
\text { follow-up } \\
\text { including } \\
\text { hospitaliz } \\
\text { ation }\end{array}$ & $\begin{array}{l}\text { (HAMD) } \\
\text { Treatment } \\
\text { remission }\end{array}$ & $\begin{array}{l}(61 \%) \\
\text { For symptoms see Supplement Figure 1a. }\end{array}$ \\
\hline $\begin{array}{l}\text { Copeland, } \\
1983 \text { (UK) }\end{array}$ & $\begin{array}{l}\text { Not } \\
\text { reported } \\
\text { Borough } \\
\text { of } \\
\text { Camberw } \\
\text { ell }\end{array}$ & $\begin{array}{l}\text { Clinical } \\
\text { diagnosis } \\
\text { (I) } \\
\text { Mixed }\end{array}$ & $\begin{array}{l}29 \text { (Not } \\
\text { reported) } \\
\text { (at follow- } \\
\text { up) }\end{array}$ & $\begin{array}{l}\text { NPD }(\mathrm{n}=18) \\
\text { (at follow-up) }\end{array}$ & $\begin{array}{l}\text { mean } 41 \text { years } \\
\text { (baseline } \\
\text { sample, } n=55 \text { ) } \\
\text { mean } 49 \text { years } \\
\text { (baseline } \\
\text { sample, } n=55 \text { ) }\end{array}$ & $\begin{array}{l}\text { Prospectiv } \\
\text { e } \\
\text { 5-year } \\
\text { follow-up }\end{array}$ & $\begin{array}{l}\text { Relapsing at } \\
\text { least once } \\
\text { Mean } \\
\text { number of } \\
\text { readmissions } \\
\text { Mean } \\
\text { number of } \\
\text { episodes }\end{array}$ & $\begin{array}{l}\text { Not included in meta-analysis: } \\
\text { Relapsing at least once: PD } 69 \% \text { vs. NPD } \\
44 \% \\
\text { Mean number of readmission: PD } 1.5 \text { vs. } \\
\text { NPD } 0.2 \text { (SD not reported) } \\
\text { Mean number of episodes: PD } 1.6 \text { vs. NPD } \\
0.6 \text { (SD not reported) }\end{array}$ \\
\hline
\end{tabular}

\section{lowa study}

Coryell et al. lowa

1986 (USA) study

\section{DSM-III}

(Not

46 (Not

reported)

Mixed

$\begin{array}{lll}\text { Coryell et al. } & 1934- & \text { DSM-III } \\ 1982 \text { (USA) } & 1940 \text { (for } & \text { (I) } \\ & \text { SZ until } & \text { Mixed } \\ & 1945) & \\ & \text { lowa } & \\ & \text { study } & \end{array}$

46 (Not
reported)

NPD $(n=159)$

Not reported

Not reported

Prospectiv At baseline Included in meta-analysis:

e and 6 months For symptoms and global outcome see

follow up: Supplement Figures 1a and 1c.

6-month depressive

follow-up (HAMD) and Not included in meta-analysis:

global Recovery, narrow: PD $37 \%$ vs. NPD $26 \%$

outcome Recovery, broad: PD 52\% vs. NPD 57\%

(GAS)

Recovery

(return to

premorbid

level of

functioning

with absence

of symptoms)

\begin{tabular}{|c|c|c|c|c|c|}
\hline \multirow{5}{*}{$\begin{array}{l}114 \text { (Not } \\
\text { reported) }\end{array}$} & \multirow{5}{*}{$\begin{array}{l}\text { NPD }(n=78) \\
\text { SZ }(n=171)\end{array}$} & \multirow{5}{*}{$\begin{array}{l}\text { Not reported } \\
\text { Median age at } \\
\text { admission } 42\end{array}$} & \multirow{5}{*}{$\begin{array}{l}\text { Prospectiv } \\
\text { e } \\
\text { Median } \\
\text { follow-up } \\
2-3 \text { years }\end{array}$} & \multirow{2}{*}{$\begin{array}{l}\text { Clinical } \\
\text { outcomes }\end{array}$} & \multirow{3}{*}{$\begin{array}{l}\text { Included in meta-analysis: } \\
\text { Unimproved (i.e. poor global clinical } \\
\text { outcome): PD } 35 \% \text { vs. NPD } 22 \% \text { vs. SZ } \\
77 \%\end{array}$} \\
\hline & & & & & \\
\hline & & & & $\begin{array}{l}\text { Recovery } \\
\text { (return to } \\
\text { premorbid }\end{array}$ & \\
\hline & & & & $\begin{array}{l}\text { level of } \\
\text { functioning } \\
\text { with absence } \\
\text { of }\end{array}$ & $\begin{array}{l}\text { Not included in meta-analysis: } \\
\text { Recovered: PD } 40 \% \text { vs. NPD } 69 \% \text { vs. SZ } \\
7 \%\end{array}$ \\
\hline & & & & symptoms). & Improved (good global clinical outcome) \\
\hline
\end{tabular}




$\begin{array}{lll}\text { Coryell \& } & 1934- & \text { DSM-III } \\ \text { Tsuang, } 1982 & 1940 \text { (for } & \text { (I) } \\ \text { (USA) } & \text { SZ until } & \text { Mixed } \\ & \text { 1945) } & \\ & \text { lowa } \\ & \text { study }\end{array}$

$\begin{array}{llllll}\text { Coryell \& } & 1934- & \text { DSM-III } & 190(\text { Not } & \text { NPD }(n=106), & \text { Not reported } \\ \text { Tsuang, } 1985 & 1940 \text { (for } & \text { delusional } & \text { reported) } & \text { SZ }(n=219) & \text { Not reported } \\ \text { (USA) } & \text { SZ until } & \text { depression } & & & \\ & \text { 1945) } & \text { (I) } & & & \\ & \text { lowa } & \text { Mixed } & & & \\ \text { study } & & & \end{array}$

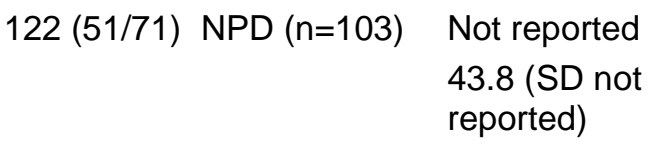

PD $25 \%$ vs. NPD $10 \%$ vs. SZ $16 \%$

\section{Comment:}

Schizophreniform disorder group $(n=48)$ results not presented here.

Not

reported

Mean

Clinical

outcomes

low up (return to

time 3.4- premorbid

5.0 years level of

functioning

with absence

of

symptoms). Follow-up:

Not included in meta-analysis:

Condition at discharge:

Recovered: PD 28\% (34/121) vs. NPD 46\% (47/102)

Improved: PD 19\% (23/121) vs. NPD 18\% (18/102)

Unimproved: PD 53\% (64/121) vs. NPD $36 \%(37 / 102)$

Recovered: PD 47\% (51/108) vs. NPD 73\% (69/95)

Improved: PD 21\% vs. NPD 7\%

Unimproved: PD $32 \%$ vs. NPD $20 \%$

Prospectiv Occupational Not included in meta-analysis:

e Mental Occupational outcome:

40-year follow-up

or until the

time of

death

Good: PD 60\% vs. NPD 68\% vs. SZ 36\%

Poor (\%): PD $28 \%$ vs. NPD $18 \%$ vs. SZ

$57 \%$

Mental outcome:

Good: PD 55\% vs. NPD 56\% vs. SZ 22\% Poor: PD $29 \%$ vs. NPD $18 \%$ vs. SZ 53\%

\section{Comment:}

$43-78 \%$ of the sample were deceased and rated based on medical records.

Schizophreniform disorder group $(n=87)$, results not presented here.

\begin{tabular}{lll}
\hline NIMH study & & \\
Coryell et al. & $1978-$ & RDC \\
1984a (USA) & 1981 & $(\mathrm{I} / \mathrm{O})$ \\
& Five & Mixed \\
& centers & \\
& Boston,
\end{tabular}

Symptomatic recovery (i.e. symptomatic remission) at any time: PD $46 \%$ vs. NPD $57 \%$

For global outcome see Supplement Figure
Included in meta-analysis: 
Chicago,

lowa, New

York, St

Louis

(NIMH

study)

$\begin{array}{ll}\text { Coryell et al. } & 1978- \\ 1990 \text { (USA) } & 1981 \\ & \text { Five } \\ & \text { centers } \\ & \text { Boston, } \\ & \text { Chicago, } \\ & \text { lowa, New } \\ & \text { York, St } \\ & \text { Louis } \\ & \text { (NIMH } \\ & \text { study) }\end{array}$

remission) at $1 \mathrm{c}$.

any time Not included in meta-analysis:

Mild, $\quad$ Mild, moderate or severe work impairment:

moderate or PD 71\%(17/24) vs. NPD 34\% (52/152)

severe work Comment:

impairment

Schizoaffective disorder group $(n=24)$, results not reported here.

$\begin{array}{lll}73(24 / 49) & \text { SZAFF } & \text { Not reported } \\ \text { completers, } & \text { depressed } & \text { At intake } 39.2 \\ 19(8 / 11) & \text { type } & (14.9) \\ \text { noncomplet } & \text { (completers } & \text { completers, } \\ \text { ers } & n=30, & 38.6(16.6) \\ & n=12) & \\ & n=12) & \end{array}$

Prospectiv Global

e outcome

5-year (GAS)

follow-up Recovery

Relapses

tions

Symptoms
Not included in meta-analysis:

Symptomatic recovery from index episode: PD $89 \%$ vs. SZAFF $73 \%$

Sustained psychotic features during final 6 months: PD $12 \%$ vs. SZAFF $30 \%$

liza Mean GAS at intake: PD completers 35.8, PD non completers 34.7, SZAFF

completers 32.5, SZAFF non-completers 41.3.

Mean GAS at last contact PD completers 58.0, PD non completers 46.5, SZAFF completers 55.9, SZAFF non-completers 32.6.

Rehospitalized in the follow-up: PD 56\%, SZAFF $77 \%$

Comment:

Partly overlapping sample with Coryell et al. (1984a, 1987).

Not included in meta-analysis:

Prospectiv Global

e outcome

2-year (GAS) follow-up Recovery
Mean GAS score: at 6 months PD 61 vs.

NPD 55; at 24 months PD 63 vs. NPD 61.

Symptomatic recovery from index episode by 6 months: PD 53\% vs, NPD 58\%

Symptomatic recovery from index episode by 2 years: PD $75 \%$ vs. NPD $83 \%$

Comment:

Partly overlapping sample with Coryell et al. (1984a, 1990). 


\begin{tabular}{|c|c|c|c|c|c|c|c|c|}
\hline (Italy) & Pisa & Mixed & & & & $\begin{array}{l}\text { No follow- } \\
\text { up }\end{array}$ & $\begin{array}{l}\text { global } \\
\text { outcome } \\
\text { (GAF), } \\
\text { unemployme } \\
\text { nt }\end{array}$ & $\begin{array}{l}\text { Supplement Figures 3a-3d. } \\
\text { Not included in meta-analysis: } \\
\text { Unemployment rate: PD } 63 \% \text {, bipolar mania } \\
60 \% \text {, bipolar mixed episode } 69 \% \text {, } \\
\text { depressed bipolar } 53 \% \\
\text { Comment: } \\
\text { PBD groups (pure mania }(n=55) \text {, with mixed } \\
\text { mania }(n=62) \text {, with bipolar depression } \\
(n=30) \text { ) were studied separately. }\end{array}$ \\
\hline $\begin{array}{l}\text { Gaudiano et } \\
\text { al. } 2009 \\
\text { (USA) }\end{array}$ & $\begin{array}{l}\text { Not } \\
\text { reported } \\
\text { Rhode } \\
\text { Island } \\
\text { (MIDAS } \\
\text { project, } \\
\text { data } \\
\text { collected } \\
\text { from the } \\
1980 \text { 's, } \\
\text { still } \\
\text { ongoing) }\end{array}$ & $\begin{array}{l}\text { DSM-IV } \\
(\mathrm{O}) \\
\text { Mixed }\end{array}$ & $60(16 / 44)$ & NPD $(n=1052)$ & $\begin{array}{l}20.7(12.1) \\
37.0(11.7)\end{array}$ & $\begin{array}{l}\text { Cross- } \\
\text { sectional } \\
\text { No follow- } \\
\text { up }\end{array}$ & $\begin{array}{l}\text { Global } \\
\text { outcome } \\
\text { (GAF) }\end{array}$ & $\begin{array}{l}\text { Included in meta-analysis: } \\
\text { See Supplement Figure 1c for GAF. } \\
\text { Comment: } \\
\text { See also partly overlapping sample } \\
\text { Gaudiano and Zimmerman, } 2010 \text { (USA) } \\
\text { (results not presented here) }\end{array}$ \\
\hline $\begin{array}{l}\text { Gaudiano et } \\
\text { al. } 2016 \\
\text { (USA) }\end{array}$ & $\begin{array}{l}2013 \\
\text { Rhode } \\
\text { Island }\end{array}$ & $\begin{array}{l}\text { DSM-IV-TR } \\
(\mathrm{I} / \mathrm{O}) \\
\text { Mixed }\end{array}$ & $\begin{array}{l}174 \\
(74 / 100)\end{array}$ & $\operatorname{NPD}(n=1140)$ & $\begin{array}{l}\text { Not reported } \\
44.9(12.3)\end{array}$ & $\begin{array}{l}\text { Retrospec } \\
\text { tive } \\
\text { No follow- } \\
\text { up }\end{array}$ & $\begin{array}{l}\text { Global } \\
\text { outcome } \\
\text { (GAF) }\end{array}$ & $\begin{array}{l}\text { Included in meta-analysis: } \\
\text { See Supplement Figure 1c for GAS. }\end{array}$ \\
\hline $\begin{array}{l}\text { Goethe \& } \\
\text { Szarek, } 1988 \\
\text { (USA) }\end{array}$ & $\begin{array}{l}1981- \\
1985 \\
\text { Admission } \\
\text { s to } \\
\text { private } \\
\text { hospital }\end{array}$ & $\begin{array}{l}\text { DSM-III } \\
\text { (I) } \\
\text { Mixed }\end{array}$ & $77(22 / 55)$ & NPD $(n=360)$ & $\begin{array}{l}\text { Not reported } \\
52(19.24)\end{array}$ & $\begin{array}{l}\text { Cross } \\
\text { sectional } \\
\text { No follow- } \\
\text { up }\end{array}$ & $\begin{array}{l}\text { Condition on } \\
\text { discharge } \\
\text { (symptomatic } \\
\text { remission } \\
\text { and poor } \\
\text { clinical } \\
\text { outcome) }\end{array}$ & $\begin{array}{l}\text { Recovery (i.e. symptomatic remission): PD } \\
4 \% \text { vs. NPD } 4 \% \\
\text { Unimproved (i.e. poor global clinical } \\
\text { outcome): PD } 8 \% \text { vs. NPD } 8 \% \\
\text { Comment: } \\
\text { See also partly overlapping sample (Goethe } \\
\text { et al.1988) (results not presented here) }\end{array}$ \\
\hline
\end{tabular}

\section{Chicago}

follow-up

Goldberg \&

Harrow, 2004 reported

$\begin{array}{lll}\text { RDC } & 17(\text { Not } & \text { NPD }(n=72) \\ (I) & \text { reported }) & \\ \text { Mixed } & \end{array}$

For the whole Prospectiv Global sample

Fo $(n=123)$ mean

age at index follow-up

outcome
(data from
several

Not included in meta-analysis:

Good overall outcome:

At 2 years: PD $27 \%$ vs. NPD $40 \%$ 
study

\begin{tabular}{|c|c|c|c|c|c|c|c|c|}
\hline & study & & & & $\begin{array}{l}\text { hospitalization } \\
23.2(3.8)\end{array}$ & $\begin{array}{l}4.5,7.5 \\
\text { and } 10 \\
\text { years }\end{array}$ & sources). & $\begin{array}{l}\text { At } 4.5 \text { years: PD } 41 \% \text { vs. NPD } 49 \% \\
\text { At } 7.5 \text { years: PD } 35 \% \text { vs. NPD } 63 \% \\
\text { At } 10 \text { years: PD } 47 \% \text { vs. NPD } 63 \%\end{array}$ \\
\hline $\begin{array}{l}\text { Kettering et } \\
\text { al. } 1987 \\
\text { (USA) }\end{array}$ & $\begin{array}{l}\text { Not } \\
\text { reported } \\
\text { Illinois, } \\
\text { Chicago } \\
\text { (subjects } \\
\text { from } \\
\text { Chicago } \\
\text { follow-up } \\
\text { study and } \\
\text { from the } \\
\text { Mental } \\
\text { Health } \\
\text { Clinical } \\
\text { Research } \\
\text { Center } \\
\text { program) }\end{array}$ & $\begin{array}{l}\text { RDC } \\
\text { (I) } \\
\text { Mixed }\end{array}$ & $\begin{array}{l}31 \text { (Not } \\
\text { reported) }\end{array}$ & $\begin{array}{l}\operatorname{NPD}(n=28) \\
S Z(n=51)\end{array}$ & $\begin{array}{l}\text { For the whole } \\
\text { study group at } \\
\text { follow-up } 27.5 \\
\text { [range 19-56] }\end{array}$ & $\begin{array}{l}\text { Prospectiv } \\
\text { e } \\
\text { Average } \\
\text { of 14- } \\
\text { months } \\
\text { follow-up } \\
\text { [range } \\
12-26]\end{array}$ & $\begin{array}{l}\text { Global } \\
\text { outcome } \\
\text { (GAS) } \\
\text { Depressive } \\
\text { symptoms } \\
\text { (Katz } \\
\text { adjustment } \\
\text { scale, } \\
\text { depressed } \\
\text { mood) }\end{array}$ & $\begin{array}{l}\text { Included in meta-analysis: } \\
\text { See depressive symptoms and GAS in } \\
\text { Online Supplement Figures } 1 \mathrm{a} \text { and } 1 \mathrm{c} .\end{array}$ \\
\hline $\begin{array}{l}\text { Sands \& } \\
\text { Harrow, } 1994 \\
\text { (USA) }\end{array}$ & $\begin{array}{l}\text { Not } \\
\text { reported } \\
\text { exactly } \\
\text { Illinois, } \\
\text { Chicago } \\
\text { (subjects } \\
\text { from } \\
\text { Chicago } \\
\text { follow-up } \\
\text { study and } \\
\text { from other } \\
\text { clinical } \\
\text { research } \\
\text { centers) }\end{array}$ & $\begin{array}{l}\text { RDC } \\
\text { (I) } \\
\text { Mixed }\end{array}$ & $\begin{array}{l}31(\text { Not } \\
\text { reported) }\end{array}$ & NPD $(n=63)$ & $\begin{array}{l}\text { Age at index } \\
\text { hospitalization } \\
\text { for the whole } \\
\text { the Chicago } \\
\text { Follow-Up } \\
\text { group } 23.7 \\
\text { (3.6); for the } \\
\text { patients from } \\
\text { the mental } \\
\text { health clinical } \\
\text { research } \\
\text { center } 34.4 \\
(13.2) \text {. }\end{array}$ & $\begin{array}{l}\text { Prospectiv } \\
\text { e } \\
\text { Mean } 2.4 \\
\text { years, } \\
\text { range } 1-5 \\
\text { years }\end{array}$ & $\begin{array}{l}\text { Clinical } \\
\text { depression } \\
\text { symptoms } \\
\text { during last } \\
\text { follow-up } \\
\text { year (based } \\
\text { on SADS) }\end{array}$ & $\begin{array}{l}\text { Included in meta-analysis: } \\
\text { Remission: PD } 19 \% \text { vs. NPD } 29 \% \\
\text { Comment: } \\
\text { Recruited during index hospitalization from } \\
\text { two hospitals. }\end{array}$ \\
\hline $\begin{array}{l}\text { Gournellis et } \\
\text { al. } 2001 \\
\text { (Greece) }\end{array}$ & $\begin{array}{l}1997- \\
2000 \\
\text { Athens }\end{array}$ & $\begin{array}{l}\text { DSM-IV } \\
\text { (I) } \\
\text { Consecutiv } \\
\text { e }\end{array}$ & $45(14 / 31)$ & NPD $(n=73)$ & $\begin{array}{l}58.3(15.2) \\
69.6(5.8)\end{array}$ & $\begin{array}{l}\text { Prospectiv } \\
\text { e } \\
\text { No follow- } \\
\text { up }\end{array}$ & $\begin{array}{l}\text { Depression } \\
\text { symptoms } \\
\text { (HAMD) }\end{array}$ & $\begin{array}{l}\text { Included in meta-analysis: } \\
\text { See Supplement Figure 1a for HAMD. } \\
\text { Comment: } \\
\text { Elderly patients. }\end{array}$ \\
\hline $\begin{array}{l}\text { Johnson et al. } \\
1991 \text { (USA) }\end{array}$ & $\begin{array}{l}1980- \\
1985\end{array}$ & $\begin{array}{l}\text { DSM-III } \\
(I / O)\end{array}$ & $\begin{array}{l}92(\text { Not } \\
\text { reported) }\end{array}$ & NPD $(n=532)$ & $\begin{array}{l}29.0(13.9) \\
42.0(16.2)\end{array}$ & $\begin{array}{l}\text { Cross- } \\
\text { sectional }\end{array}$ & $\begin{array}{l}\text { Currently } \\
\text { depressed }\end{array}$ & $\begin{array}{l}\text { Not included in meta-analysis: } \\
\text { Currently depressed; PD } 19 \% \text { vs. NPD }\end{array}$ \\
\hline
\end{tabular}




\begin{tabular}{|c|c|c|c|c|c|c|c|c|}
\hline & $\begin{array}{l}\text { New } \\
\text { Haven, St } \\
\text { Louis, } \\
\text { Baltimore, } \\
\text { Durham, } \\
\text { and Los } \\
\text { Angeles } \\
\text { (ECA } \\
\text { study) }\end{array}$ & Mixed & & & & $\begin{array}{l}\text { 1-year } \\
\text { follow-up }\end{array}$ & (last month) & $11 \%$. \\
\hline $\begin{array}{l}\text { Jäger et al. } \\
2005 \\
\text { (Germany) }\end{array}$ & $\begin{array}{l}1980- \\
1982 \\
\text { Munich }\end{array}$ & $\begin{array}{l}\text { ICD-9 and } \\
\text { DSM-IV } \\
\text { (I) } \\
\text { Mixed }\end{array}$ & $20(4 / 16)$ & $\begin{array}{l}\operatorname{NPD}(n=33) \\
\text { SZ }(n=64)\end{array}$ & $\begin{array}{l}39.2(14.7) \\
\text { Not reported }\end{array}$ & $\begin{array}{l}\text { Retrospec } \\
\text { tive } \\
\text { 15-year } \\
\text { follow-up }\end{array}$ & $\begin{array}{l}\text { Global } \\
\text { outcome } \\
\text { (GAS) } \\
\text { Symptoms } \\
\text { (PANSS, } \\
\text { SANS, } \\
\text { HAMD) } \\
\text { Rehospitaliza } \\
\text { tions } \\
\text { Employment }\end{array}$ & $\begin{array}{l}\text { Included in meta-analysis: } \\
\text { For symptoms, global outcome and } \\
\text { hospitalizations see Supplement Figures } \\
\text { 1a-c and f, and } 2 a-e . \\
\text { Not included in meta-analysis: } \\
\text { Regular employment: PD 79\%, NPD 78\%, } \\
\text { SZ } 47 \% \\
\text { Mean number of rehospitalizations: PD } 2.8 \\
\text { vs. SZ } 2.9(p=0.045) \text {. }\end{array}$ \\
\hline $\begin{array}{l}\text { Karaaslan et } \\
\text { al. } 2003 \\
\text { (Turkey) }\end{array}$ & $\begin{array}{l}\text { Not } \\
\text { reported }\end{array}$ & $\begin{array}{l}\text { DSM IV } \\
\text { (I) } \\
\text { Mixed }\end{array}$ & $16(8 / 8)$ & $\begin{array}{l}\operatorname{NPD}(n=20) \\
\mathrm{HC}(\mathrm{n}=20)\end{array}$ & $\begin{array}{l}\text { Not reported } \\
36.45(8.65)\end{array}$ & $\begin{array}{l}\text { Cross- } \\
\text { sectional } \\
\text { No follow- } \\
\text { up }\end{array}$ & $\begin{array}{l}\text { Depressive } \\
\text { symptoms } \\
\text { (HAMD) }\end{array}$ & $\begin{array}{l}\text { Included in meta-analysis: } \\
\text { See Supplement Figure 1a for HAMD. } \\
\text { Comment: } \\
\text { Only patients who had not taken any } \\
\text { psychotropic medications during last } 4 \\
\text { week were included. }\end{array}$ \\
\hline $\begin{array}{l}\text { Kuhs, } 1991 \\
\text { (Germany) }\end{array}$ & $\begin{array}{l}1985- \\
1987 \\
\text { Münster }\end{array}$ & $\begin{array}{l}\text { ICD-9 and } \\
\text { DSM-III } \\
\text { (I) } \\
\text { Mixed }\end{array}$ & $23(12 / 11)$ & NPD $(n=137)$ & $\begin{array}{l}\text { Not reported } \\
54.7(13.3)\end{array}$ & $\begin{array}{l}\text { Cross- } \\
\text { sectional } \\
\text { No follow- } \\
\text { up }\end{array}$ & $\begin{array}{l}\text { Depressive } \\
\text { symptoms } \\
\text { (HAMD) }\end{array}$ & $\begin{array}{l}\text { Included in meta-analysis: } \\
\text { See Supplement Figure 1a for HAMD. }\end{array}$ \\
\hline $\begin{array}{l}\text { Lee et al. } \\
2003 \\
\text { (Taiwan) }\end{array}$ & $\begin{array}{l}\text { Not } \\
\text { reported } \\
\text { Taipei }\end{array}$ & $\begin{array}{l}\text { DSM-IV } \\
\text { (I) } \\
\text { Mixed }\end{array}$ & $48(33 / 5)$ & NPD $(n=108)$ & $\begin{array}{l}67.9(13.1) \\
74.7(6.1)\end{array}$ & $\begin{array}{l}\text { Cross- } \\
\text { sectional } \\
\text { No follow- } \\
\text { up }\end{array}$ & $\begin{array}{l}\text { Depressive } \\
\text { symptoms } \\
\text { (HAMD) }\end{array}$ & $\begin{array}{l}\text { Included in meta-analysis: } \\
\text { See Supplement Figure 1a for HAMD. } \\
\text { Comment: } \\
\text { Elderly sample, hospital for veterans. }\end{array}$ \\
\hline $\begin{array}{l}\text { Lykouras et } \\
\text { al. } 1986 \\
\text { (Greece) }\end{array}$ & $\begin{array}{l}1982- \\
1984 \\
\text { Athens }\end{array}$ & $\begin{array}{l}\text { DSM-III } \\
\text { (I) } \\
\text { Mixed }\end{array}$ & $\begin{array}{l}22(\text { Not } \\
\text { reported })\end{array}$ & NPD $(n=36)$ & $\begin{array}{l}\text { Not reported } \\
\text { Not reported }\end{array}$ & $\begin{array}{l}\text { Cross- } \\
\text { sectional } \\
\text { No follow- } \\
\text { up }\end{array}$ & $\begin{array}{l}\text { Depressive } \\
\text { symptoms } \\
\text { (HAMD) }\end{array}$ & $\begin{array}{l}\text { Included in meta-analysis: } \\
\text { See Supplement Figure 1a for HAMD. }\end{array}$ \\
\hline
\end{tabular}




\begin{tabular}{|c|c|c|c|c|c|c|c|c|}
\hline $\begin{array}{l}\text { Maj et al. } \\
1990 \text { (Italy) }\end{array}$ & $\begin{array}{l}1980- \\
1982 \\
\text { Naples }\end{array}$ & $\begin{array}{l}\text { DSM-III } \\
\text { (I) } \\
\text { Mixed }\end{array}$ & $36(15 / 21)$ & NPD $(n=36)$ & $\begin{array}{l}32.0(3.0) \\
42.0(6.3)\end{array}$ & $\begin{array}{l}\text { Prospectiv } \\
\text { e } \\
\text { 7-year } \\
\text { follow-up }\end{array}$ & $\begin{array}{l}\text { Global } \\
\text { outcome } \\
\text { (GAS), } \\
\text { psychosis } \\
\text { symptoms } \\
\text { (CPRS) }\end{array}$ & $\begin{array}{l}\text { Included in meta-analysis: } \\
\text { See Supplement Figure } 1 \mathrm{~b} \text { and c for } \\
\text { psychosis symptoms and global outcome. }\end{array}$ \\
\hline $\begin{array}{l}\text { Park et al. } \\
2014 a \\
\text { (South Korea) }\end{array}$ & $\begin{array}{l}\text { 1/2006- } \\
8 / 2008 \\
18 \\
\text { hospitals } \\
\text { (CRESCE } \\
\text { ND study) }\end{array}$ & $\begin{array}{l}\text { DSM-IV } \\
(\mathrm{I} / \mathrm{O}) \\
\text { Mixed }\end{array}$ & $53(17 / 36)$ & $\operatorname{NPD}(n=441)$ & $\begin{array}{l}\text { Not reported } \\
40.7 \text { (15.2) }\end{array}$ & $\begin{array}{l}\text { Cross- } \\
\text { sectional } \\
\text { No follow- } \\
\text { up }\end{array}$ & $\begin{array}{l}\text { Depressive } \\
\text { and total } \\
\text { psychotic } \\
\text { symptoms } \\
\text { (HAMD-17, } \\
\text { BPRS) } \\
\text { Global } \\
\text { outcome } \\
\text { (SOFAS) } \\
\text { Employment }\end{array}$ & $\begin{array}{l}\text { Included in meta-analysis: } \\
\text { For symptoms and global outcome see } \\
\text { Supplement Figures 1a-c. } \\
\text { Not included in meta-analysis: } \\
\text { Employed: PD } 73 \% \text { vs. NPD } 73 \% \\
\text { Comment: } \\
\text { Patients in beginning of treatment for first } \\
\text { episode or recurrent depression. }\end{array}$ \\
\hline $\begin{array}{l}\text { Park et al. } \\
\text { 2014b (South } \\
\text { Korea) }\end{array}$ & $\begin{array}{l}2006- \\
2008 \\
18 \\
\text { hospitals } \\
\text { (CRESCE } \\
\text { ND study) }\end{array}$ & $\begin{array}{l}\text { DSM-IV } \\
(\mathrm{I} / \mathrm{O}) \\
\text { Mixed }\end{array}$ & $24(6 / 18)$ & $\operatorname{NPD}(n=942)$ & $\begin{array}{l}\text { Not reported } \\
44.7(18.5)\end{array}$ & $\begin{array}{l}\text { Cross- } \\
\text { sectional } \\
\text { or } 8 \text { years } \\
\text { (not } \\
\text { clearly } \\
\text { reported) }\end{array}$ & $\begin{array}{l}\text { Symptoms } \\
\text { (HAMD, } \\
\text { BPRS) } \\
\text { Global } \\
\text { outcome } \\
\text { (SOFAS) } \\
\text { Employment }\end{array}$ & $\begin{array}{l}\text { Not included in meta-analysis: } \\
\text { Employed: PD } 68 \% \text { vs. NPD } 75 \% \text {. } \\
\text { SOFAS mean score: PD } 53.9 \text { vs. NPD } 57.4 \text {. } \\
\text { HAMD mean score: PD } 21.6 \text { vs. NPD } 20.2 \text {. } \\
\text { BPRS mean score: PD } 41.5 \text { vs. NPD } 20.9 . \\
\text { Comment: } \\
\text { Patients in beginning of treatment for first } \\
\text { episode or recurrent depression. Results } \\
\text { not in meta-analysis, due to overlap with } \\
\text { Park et al. (2014a). }\end{array}$ \\
\hline $\begin{array}{l}\text { Politis et al. } \\
2004 \\
\text { (Greece) }\end{array}$ & $\begin{array}{l}\text { Not } \\
\text { reported } \\
\text { Athens }\end{array}$ & $\begin{array}{l}\text { DSM-IV } \\
\text { (I) } \\
\text { Mixed }\end{array}$ & $16(8 / 8)$ & NPD $(n=16)$ & $\begin{array}{l}\text { Not reported } \\
49(15)\end{array}$ & $\begin{array}{l}\text { Cross- } \\
\text { sectional } \\
\text { No follow- } \\
\text { up }\end{array}$ & $\begin{array}{l}\text { Depressive } \\
\text { symptoms } \\
\text { (HAMD) }\end{array}$ & $\begin{array}{l}\text { Included in meta-analysis: } \\
\text { See Supplement Figure 1a for HAMD. }\end{array}$ \\
\hline $\begin{array}{l}\text { Robinson \& } \\
\text { Spiker, } 1985 \\
\text { (USA) }\end{array}$ & $\begin{array}{l}1974- \\
1982 \\
\text { Pittsburgh }\end{array}$ & $\begin{array}{l}\text { RDC } \\
\text { delusional } \\
\text { depression } \\
\text { (I) } \\
\text { Mixed }\end{array}$ & $52(19 / 33)$ & NPD $(n=52)$ & $\begin{array}{l}39.2(13.4) \\
45.6(14.2)\end{array}$ & $\begin{array}{l}\text { Prospectiv } \\
\text { e } \\
\text { 1-year } \\
\text { follow-up } \\
\text { after } \\
\text { discharge }\end{array}$ & $\begin{array}{l}\text { Clinical } \\
\text { status over } \\
\text { first years } \\
\text { Hospitalizatio } \\
\text { ns }\end{array}$ & $\begin{array}{l}\text { Included in meta-analysis: } \\
\text { Asymptomatic (i.e. remission): PD } 42 \% \text { vs. } \\
\text { NPD } 62 \% \\
\text { Chronically ill (i.e. poor global clinical } \\
\text { outcome): PD } 29 \% \text { vs. NPD } 6 \% \\
\text { Not included in meta-analysis: } \\
\text { Total number of hospitalizations: PD } 18 \text { vs. }\end{array}$ \\
\hline
\end{tabular}




\section{NPD 10 (SD not reported)}

Comment:

Controls matched for sex and age at first episode and index episode.

\begin{tabular}{|c|c|c|c|c|c|c|c|c|}
\hline $\begin{array}{l}\text { Rush et al. } \\
2006 \text { (USA) }\end{array}$ & $\begin{array}{l}1998- \\
2000 \\
\text { Austin, } \\
\text { Texas }\end{array}$ & $\begin{array}{l}\text { DSM-IV } \\
\text { (O) } \\
\text { Mixed }\end{array}$ & $106(19 / 87)$ & NPD $(n=438)$ & $\begin{array}{l}\text { Not reported } \\
41.4(10.7)\end{array}$ & $\begin{array}{l}\text { Cross- } \\
\text { sectional }\end{array}$ & $\begin{array}{l}\text { Depressive } \\
\text { symptoms } \\
\text { (IDS-C-30) } \\
\text { Employment }\end{array}$ & $\begin{array}{l}\text { Included in meta-analysis: } \\
\text { For depressive symptoms see Supplement } \\
\text { Figure 1a. } \\
\text { Not included in meta-analysis: } \\
\text { Unemployed: PD } 90 \% \text { vs. NPD } 81 \% \\
\text { Comment: } \\
\text { Most of the sample were females. }\end{array}$ \\
\hline $\begin{array}{l}\text { Simpson et } \\
\text { al. } 1999 \text { (UK) }\end{array}$ & $\begin{array}{l}\text { Not } \\
\text { reported } \\
\text { Manchest } \\
\text { er }\end{array}$ & $\begin{array}{l}\text { DSM-III-R } \\
(\mathrm{I} / \mathrm{O}) \\
\text { Mixed }\end{array}$ & $18(7 / 11)$ & $\operatorname{NPD}(\mathrm{n}=81)$ & $\begin{array}{l}63.1(11.0) \\
75.2(4.6)\end{array}$ & $\begin{array}{l}\text { Cross- } \\
\text { sectional } \\
\text { No follow- } \\
\text { up }\end{array}$ & $\begin{array}{l}\text { Depressive } \\
\text { symptoms } \\
\text { (MADRS) }\end{array}$ & $\begin{array}{l}\text { Included in meta-analysis: } \\
\text { See Supplement Figure 1a for depression } \\
\text { symptoms. } \\
\text { Comment: } \\
\text { Old-age study }\end{array}$ \\
\hline $\begin{array}{l}\text { Tsuang \& } \\
\text { Coryell, } 1993 \\
\text { (USA) }\end{array}$ & $\begin{array}{l}1979- \\
1982 \\
\text { lowa }\end{array}$ & $\begin{array}{l}\text { DSM-III-R } \\
\text { (I) } \\
\text { Mixed }\end{array}$ & $\begin{array}{l}32(6 / 26) \\
\text { [two } \\
\text { groups: } \\
\text { with mood- } \\
\text { congruent } \\
\text { ( } n=17) \text { and } \\
\text { incongruent } \\
(n=15) \\
\text { features] }\end{array}$ & $S Z(n=22)$ & $\begin{array}{l}\text { Not reported } \\
\text { Not reported }\end{array}$ & $\begin{array}{l}\text { Prospectiv } \\
\text { e } \\
\text { 8-year } \\
\text { follow-up }\end{array}$ & $\begin{array}{l}\text { Global } \\
\text { outcome } \\
\text { (GAS) }\end{array}$ & $\begin{array}{l}\text { Included in meta-analysis: } \\
\text { Please see Onluse supplement Figure } 2 e \\
\text { for GAS score. } \\
\text { Not included in meta-analysis: } \\
\text { Recovery from psychotic symptoms: PD } \\
44 \% \text { vs. SZ 0\% }\end{array}$ \\
\hline $\begin{array}{l}\text { Zaninotto et } \\
\text { al. } 2013 \\
\text { (Several } \\
\text { countries) }\end{array}$ & $\begin{array}{l}2000- \\
2004 \\
\text { European } \\
\text { multicente } \\
\text { r project } \\
\text { Brussels, } \\
\text { Leuven, } \\
\text { Milan, } \\
\text { Paris, } \\
\text { Sint- }\end{array}$ & $\begin{array}{l}\text { DSM-IV } \\
(\mathrm{I} / \mathrm{O}) \\
\text { Consecutiv } \\
\text { e }\end{array}$ & $90(25 / 65)$ & $\begin{array}{l}\text { NPD ( } n=609) \\
\text { [two groups] }\end{array}$ & $\begin{array}{l}33.9(14.7) \\
48.8 .(14.6)\end{array}$ & $\begin{array}{l}\text { Cross- } \\
\text { sectional }\end{array}$ & $\begin{array}{l}\text { Depressive } \\
\text { symptoms } \\
\text { (HAMD) }\end{array}$ & $\begin{array}{l}\text { Included in meta-analysis: } \\
\text { See Supplement Figure 1a for depression } \\
\text { symptoms. }\end{array}$ \\
\hline
\end{tabular}




\section{Truiden,}

Tel-

Hashomer

, Vienna

Abbreviations: $\mathrm{BDI}=$ Beck Depression Inventory; $\mathrm{BPRS}=$ Brief Psychiatric Rating Scale; $\mathrm{CGI}=$ Clinical Global Impression Scale $; \mathrm{Cl}=\mathrm{Confidence}$

Interval; CPRS = Comprehensive Psychopathology Rating Scale; DSM = Diagnostic and Statistical Manual of Mental disorders; ECA = Epidemiological Catchment Area, GAF = The Global Assessment of Functioning Scale; GAS = Global Assessment Scale; HAMD = Hamilton Rating Scale for Depression;

ICD = International Classification of Diseases; IDS-C-30 = Inventory of Depressive Symptomatology (30 item); MADRS = Montgomery Asberg

Depression Rating Scale; NIMH = National Institute of Mental Health; PANSS = Positive and Negative Syndrome Scale; PDAS = The Psychotic

Depression Assessment Scale; PSE = Present State Examination; SADS = Schedule for Affective Disorders and Schizophrenia (-C = Change version);

SANS = Scale for Assessment of Negative Symptoms; SAPS = Scale for Assessment of Positive Symptoms; SOFAS = Social and Occupational

Functioning Assessment Scale.

Diagnoses: $\mathrm{PD}=$ psychotic depression, NPD = nonpsychotic depression, $\mathrm{PD}=$ bipolar disorder, $\mathrm{PBD}=$ psychotic bipolar disorder, $\mathrm{SZ}=\mathrm{schizophrenia}$,

SZAFF $=$ schizoaffective disorder, $\mathrm{HC}=$ healthy controls.

Settings: $\mathrm{I}$ = inpatients, $\mathrm{O}=$ outpatients, $\mathrm{I} / \mathrm{O}=$ both in- and outpatients. 
Supplement Figure 1a. Meta-analysis on symptoms of depression in psychotic depression (PD) and non-psychotic depression (NPD) in strata by age of illness onset.

\section{Symptoms of depression in PD vs NPD}

\begin{tabular}{|c|c|c|c|c|}
\hline Reference & Instrument & $\begin{array}{l}\text { Study } \\
\text { design }\end{array}$ & $\begin{array}{l}\text { Mean } \\
\text { onset-age }\end{array}$ & $\begin{array}{l}\text { Mean } \\
\text { age }\end{array}$ \\
\hline \multicolumn{5}{|c|}{ Mean age of onset $<45$ years } \\
\hline Kettering et al. 1987 & Katz scale & M & NR & 27.5 \\
\hline Taiminen et al. 2000 & HAMD & $\mathrm{F}$ & NR & 33.3 \\
\hline Rush et al. 2006 & IDS-C-30 & M & NR & 41.4 \\
\hline Jäger et al. 2005 & HAMD & M & 39.2 & NR \\
\hline Park et al. 2014a & HAMD & M & NR & 40.7 \\
\hline Karaaslan et al. 2003 & HAMD & M & $\mathrm{NR}$ & 36.5 \\
\hline Zaninotto et al. 2013 & HAMD & c & 33.9 & 48.8 \\
\hline Buoli et al. 2013 & HAMD & M & 41.8 & 59.7 \\
\hline
\end{tabular}

Subtotal $\left(R^{2}=75.3 \%, p=0.000\right)$

Mean age of onset $\geq 45$ years

$\begin{array}{llllll}\text { Lee et al. 2003 } & \text { HAMD } & \text { M } & 67.9 & 74.7 & 48 \\ \text { Simpson et al. 1999 } & \text { MADRS } & \text { M } & 63.1 & 75.2 & 18 \\ \text { Gournellis et al. 2001 } & \text { HAMD } & \text { C } & 58.3 & 69.6 & 45\end{array}$

Subtotal $\left(R^{2}=81.7 \%, \mathrm{p}=0.004\right)$

Mean age of onset not reported

Coryell et al. $1986 \quad$ HAMD

Kuhs 1991

Politis et al. $2004 \quad$ HAMD

Lykouras et al. $1986 \quad$ HAMD

Subtotal $\left(R^{2}=89.9 \%, \mathrm{p}=0.000\right)$

$\begin{array}{llll}M & \text { NR } \quad \text { NR } & 52\end{array}$

$\begin{array}{lll}M & \text { NR } & 54.7 \quad 23\end{array}$

$\begin{array}{llll}M & \text { NR } & 49 & 16\end{array}$

NR NR 22

Overall $(R=82.6 \%, p=0.000)$
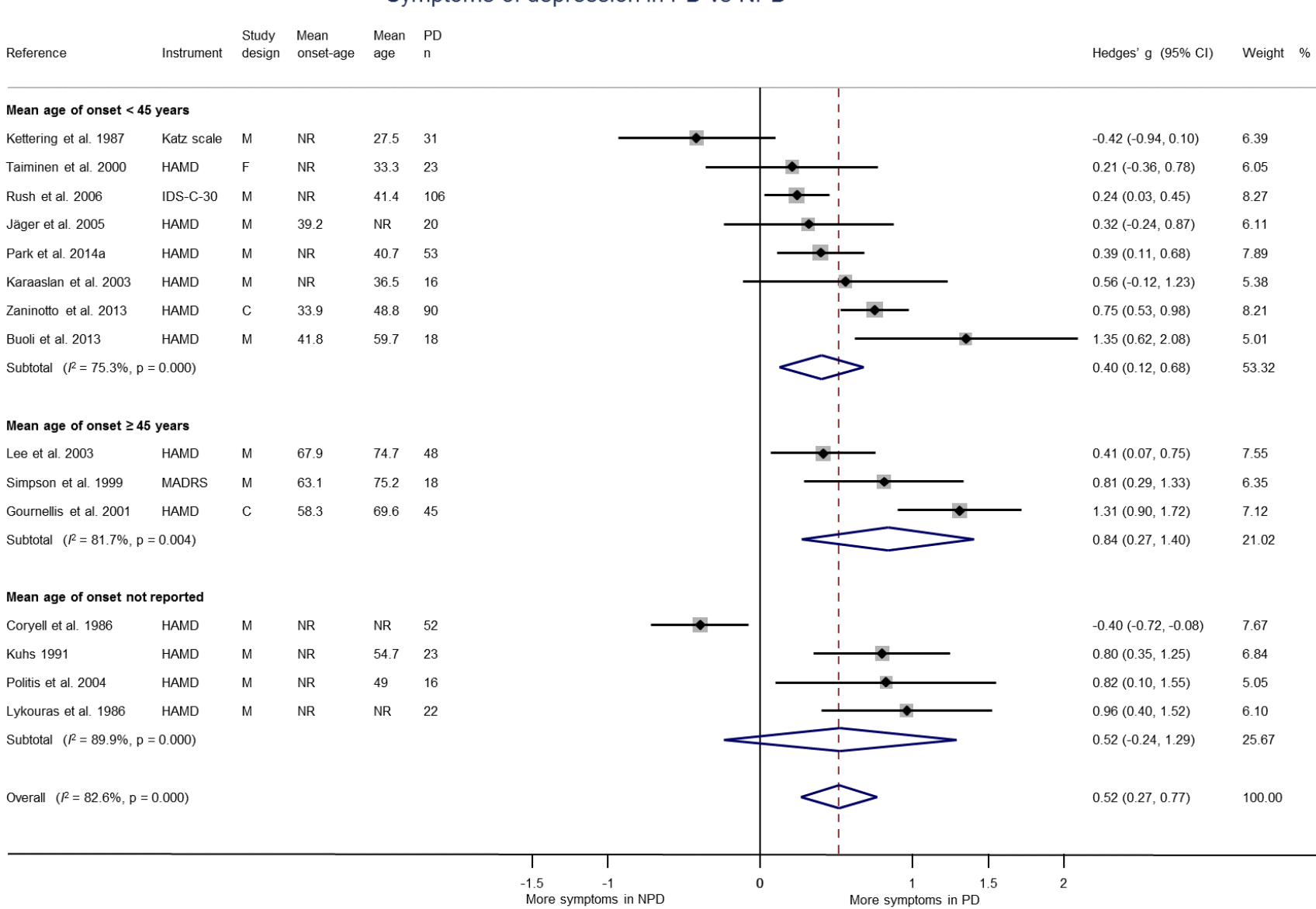

Abbreviations: $\mathrm{PD}=$ psychotic depression, $\mathrm{NPD}=$ nonpsychotic depression, $\mathrm{HAMD}=$ Hamilton Rating Scale for Depression, IDS-C-30 = Inventory of Depressive Symptomatology ( 30 item), MADRS = Montgomery-Asberg Depression Rating Scale, $\mathrm{M}=$ mixed sample, $\mathrm{F}=$ first-episode sample, $\mathrm{C}=$ consecutive sample, $\mathrm{NR}=$ not reported,$R=$ heterogeneity, $\mathrm{Cl}=$ confidence interval 
Supplement Figure 1b. Meta-analysis on total psychotic symptoms in psychotic depression (PD) and non-psychotic depression (NPD).

Psychosis symptoms (total score) in PD vs NPD

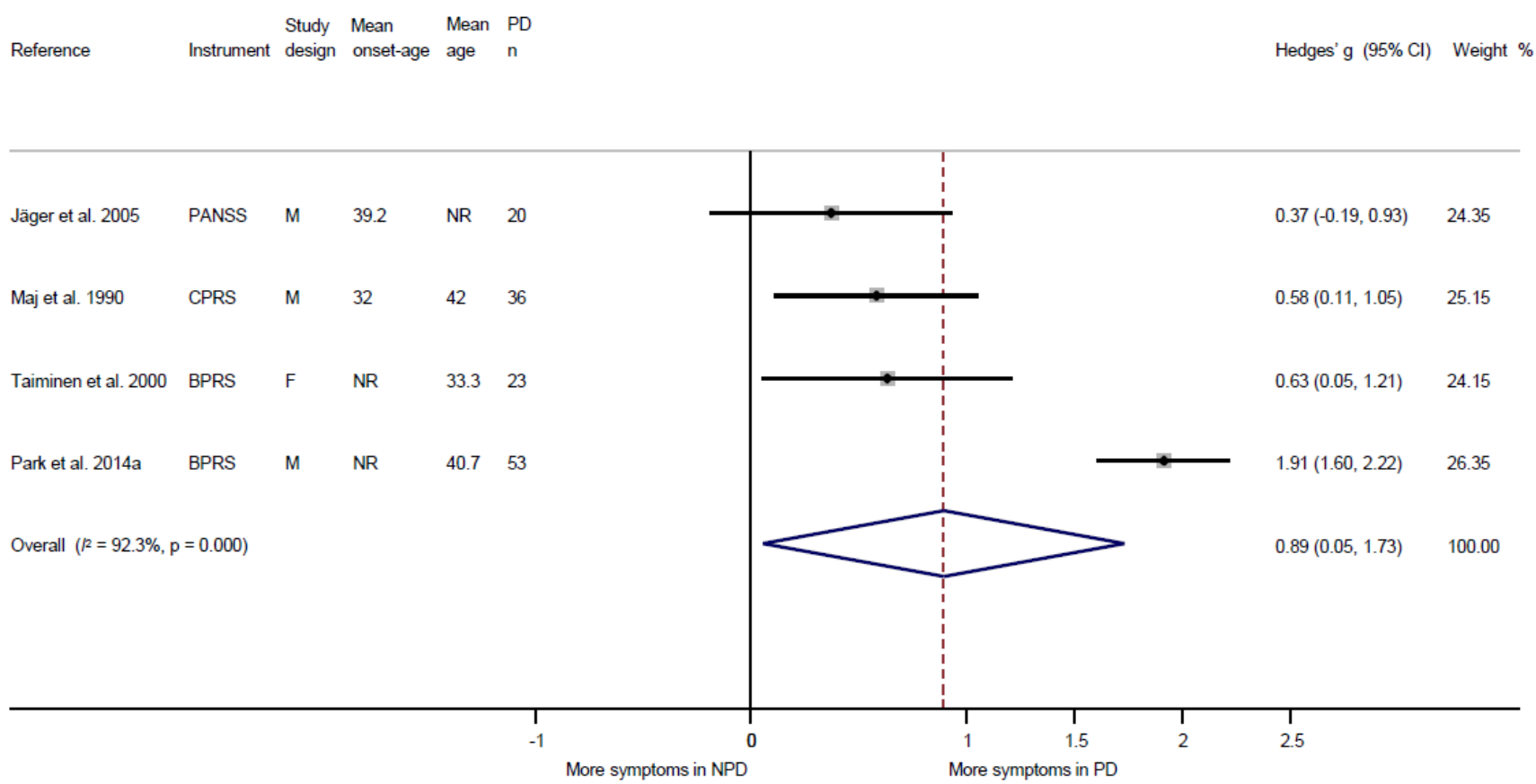

Abbreviations: PD = psychotic depression, NPD = nonpsychotic depression, PANSS = Positive and Negative Syndrome Scale,CPRS = Comprehensive Psychopathology Rating Scale, BPRS $=$ Brief Psychiatric Rating Scale, $\mathrm{M}=$ mixed sample, $\mathrm{F}=$ first-episode sample, $\mathrm{NR}=$ not reported, $\mathrm{R}=$ heterogeneity, $\mathrm{Cl}=$ confidence interval 
Supplement Figure 1c. Meta-analysis on global outcome in psychotic depression (PD) and nonpsychotic depression (NPD).

Global outcome in PD vs NPD

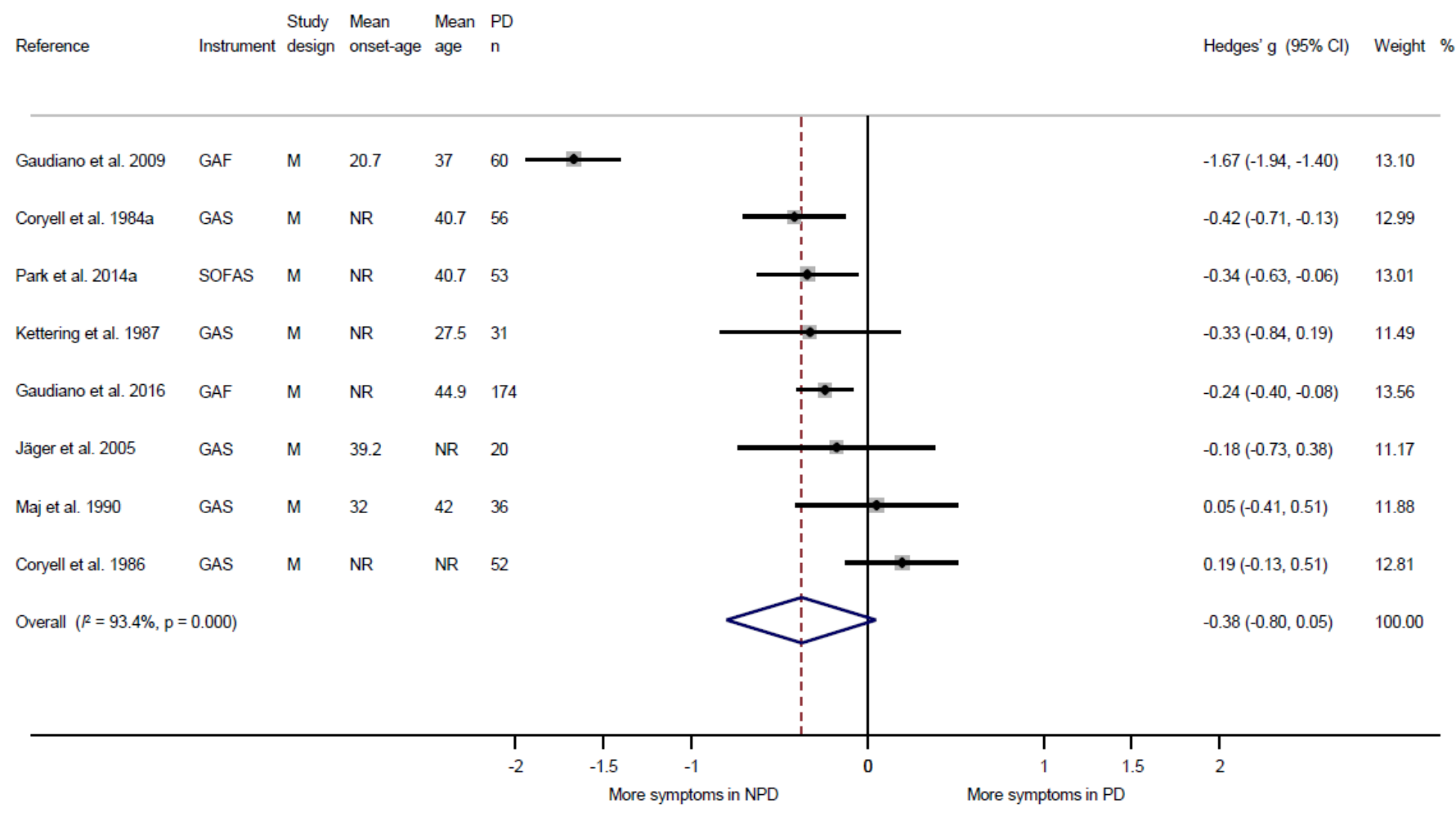

Abbreviations: $\mathrm{PD}=$ psychotic depression, NPD = nonpsychotic depression, GAF $=$ The Global Assessment of Functioning Scale, GAS $=$ Global Assessment Scale, SOFAS $=$ Social and Occupational Functioning Assessment Scale, $\mathrm{M}=$ mixed sample, $\mathrm{NR}=$ not reported, $R=$ heterogeneity, $\mathrm{Cl}=$ confidence interval . 
Supplement Figure 1d. Meta-analysis on remission in psychotic depression (PD) and non-psychotic depression (NPD).

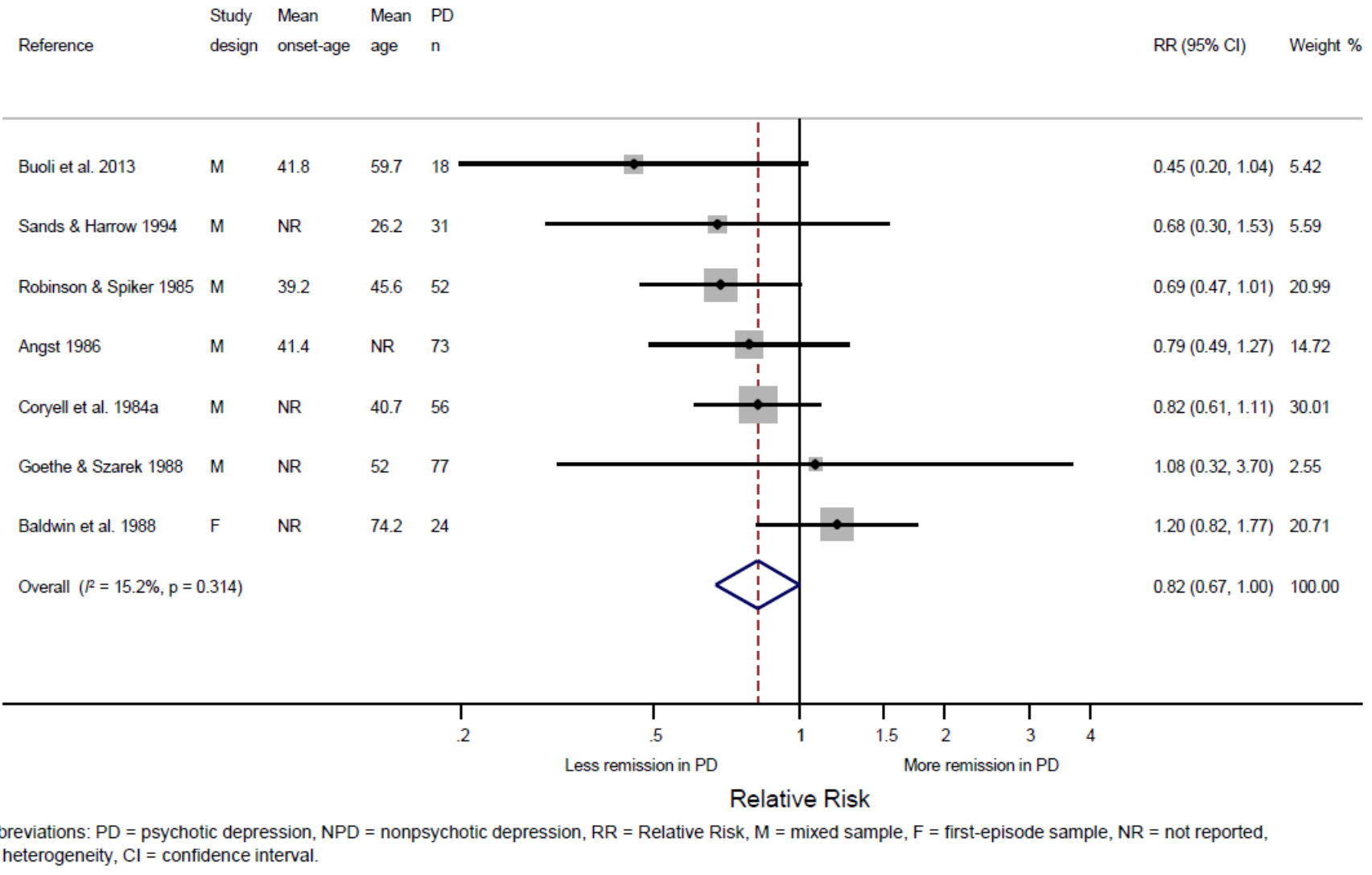


Supplement Figure 1e. Meta-analysis on poor global clinical outcome in psychotic depression (PD) and non-psychotic depression (NPD).

Poor global clinical outcome in PD and NPD

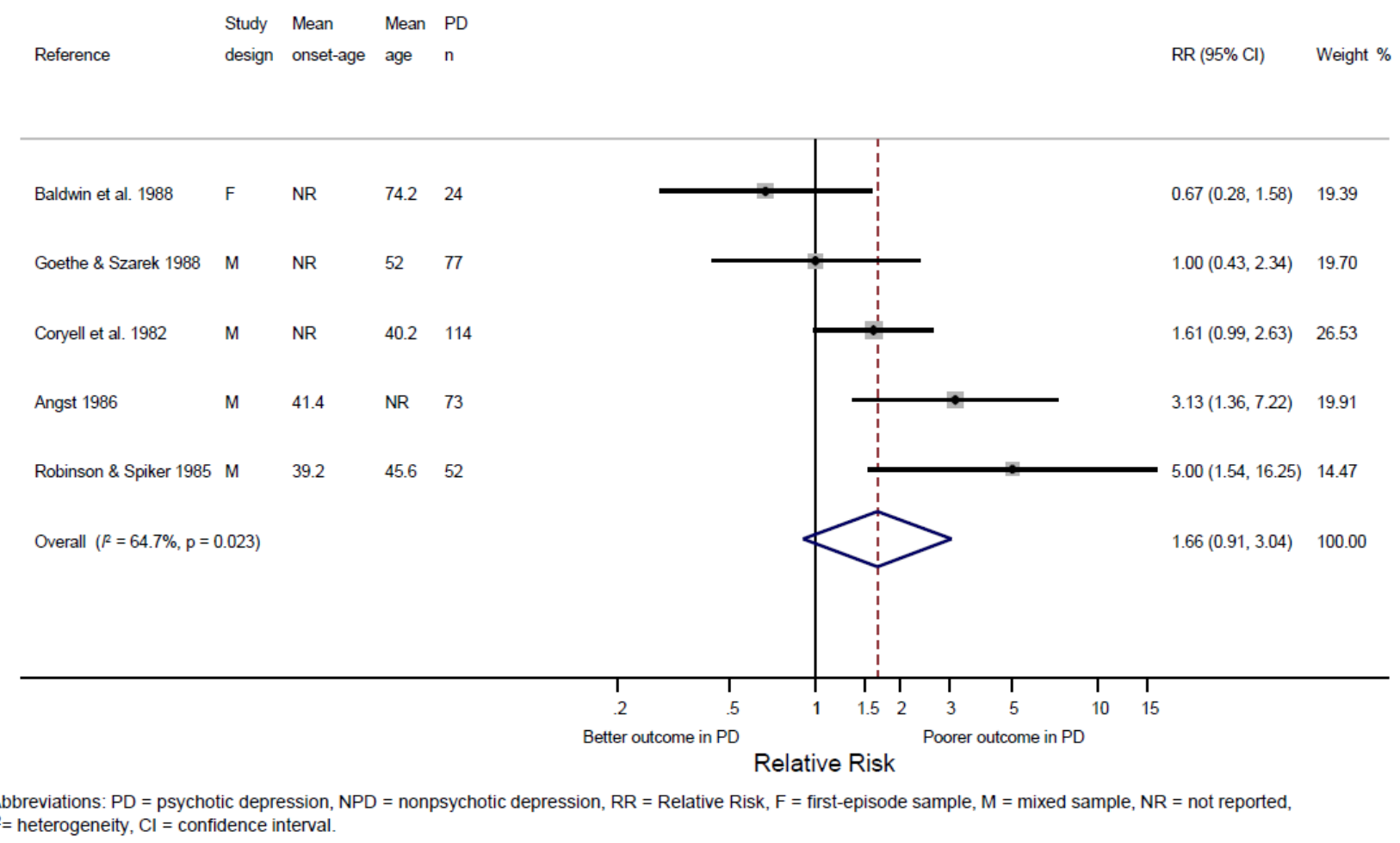


Supplement Figure 1f. Meta-analysis on hospitalization in psychotic depression (PD) and nonpsychotic depression (NPD).

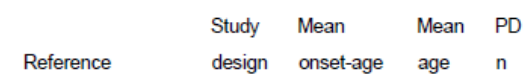

Hedges' g $(95 \% \mathrm{Cl}) \quad$ Weight \%

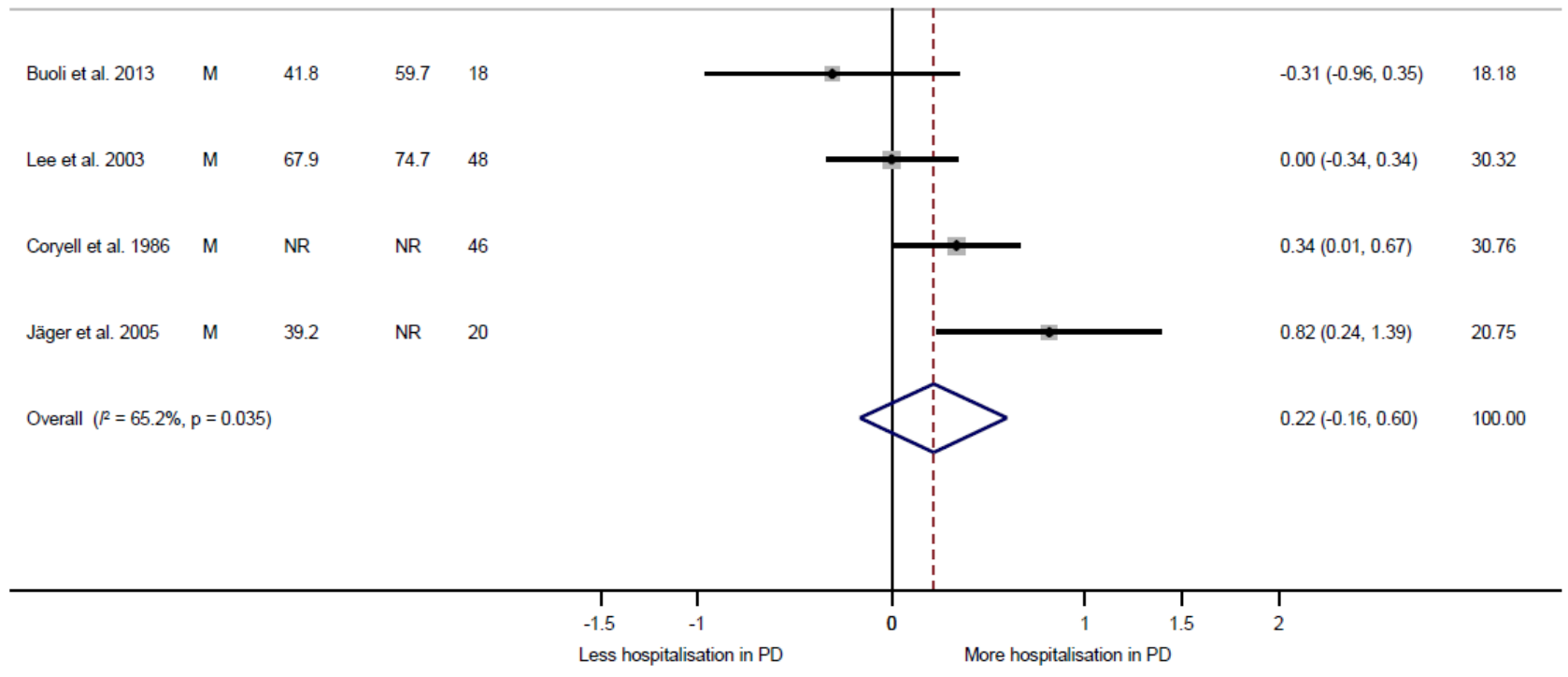

Abbreviations: $\mathrm{PD}=$ psychotic depression, $\mathrm{NPD}=$ nonpsychotic depression, $\mathrm{M}=$ mixed sample, $\mathrm{NR}=$ not reported, $\mathrm{R}=$ heterogeneity, $\mathrm{Cl}=$ confidence interval. 
Supplement Figure 2a. Meta-analysis on symptoms of depression in psychotic depression (PD) and schizophrenia (SZ).

\section{Symptoms of depression in PD vs SZ}

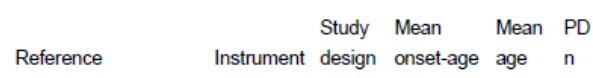

Hedges' g $(95 \% \mathrm{Cl}) \quad$ Weight $\%$

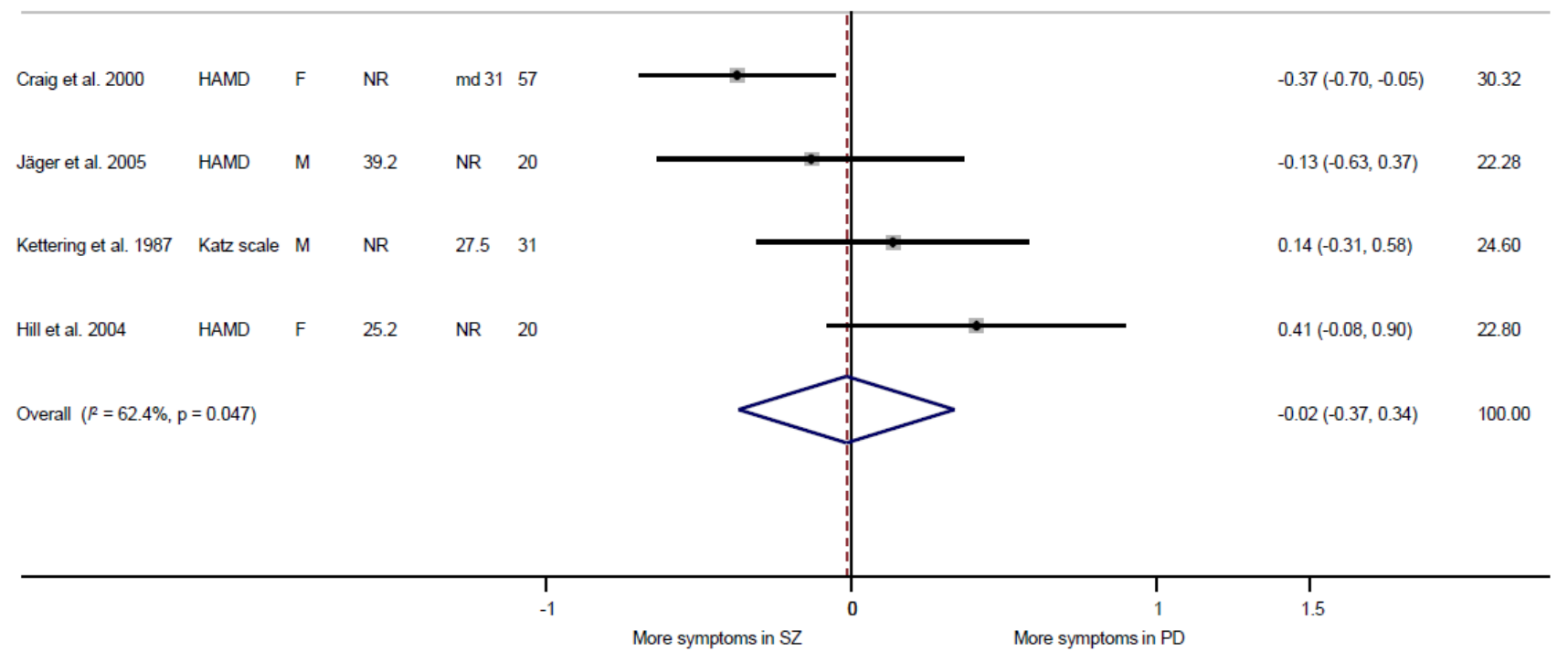

Abbreviations: $\mathrm{PD}=$ psychotic depression, $\mathrm{SZ}=$ schizophrenia, $\mathrm{HAMD}=$ Hamilton Rating Scale for Depression, $\mathrm{F}=$ first-episode sample, $\mathrm{M}=$ mixed sample, $\mathrm{NR}=$ not reported $R=$ heterogeneity, $\mathrm{Cl}=$ confidence interval. 
Supplement Figure 2b. Meta-analysis on total psychotic symptoms in psychotic depression (PD) and schizophrenia (SZ).

Psychosis symptoms (total score) in PD vs SZ

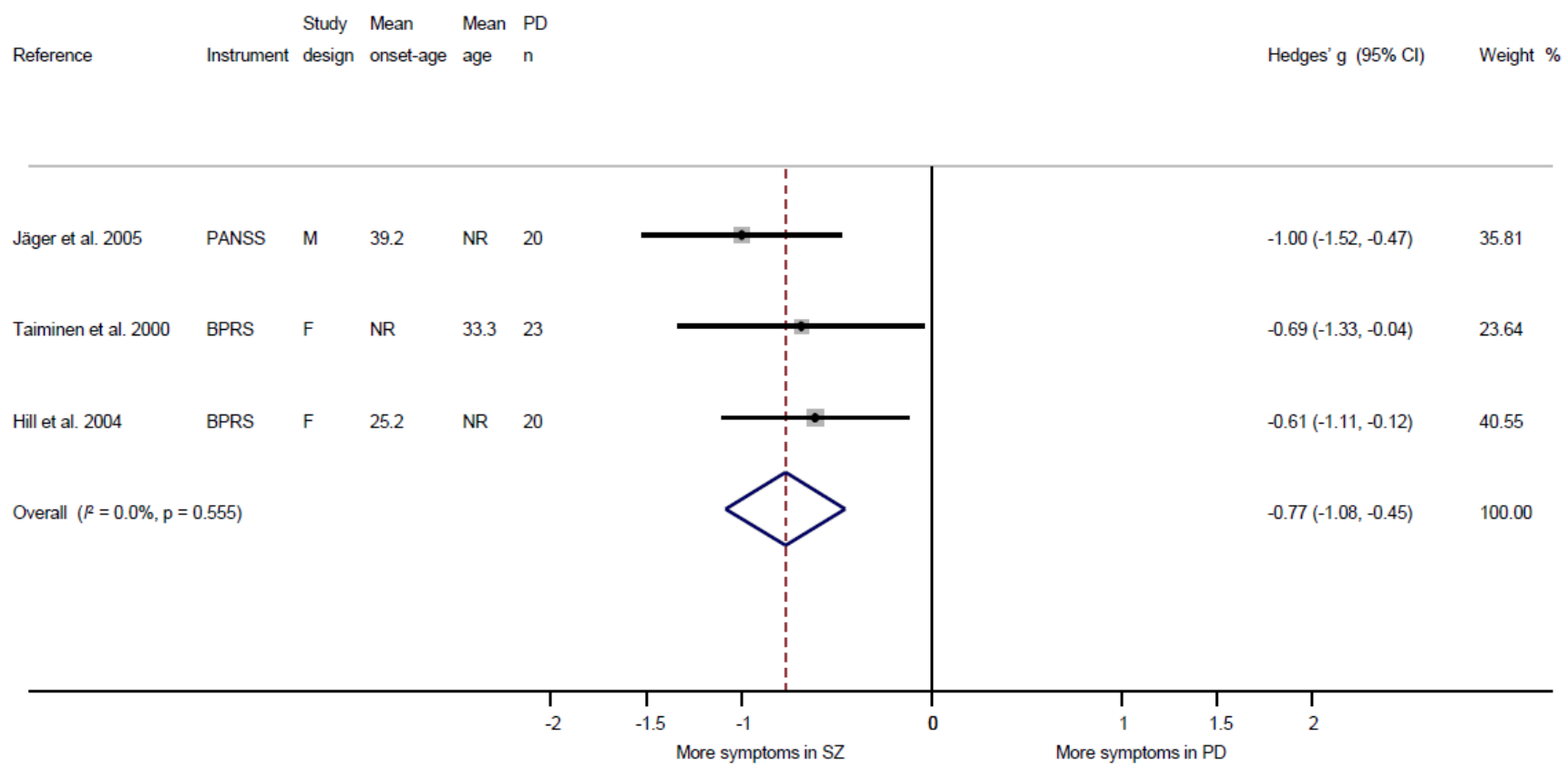

Abbreviations: PD = psychotic depression, SZ = schizophrenia, PANSS = Positive and Negative Syndrome Scale, BPRS = Brief Psychiatric Rating Scale, M = mixed sample, F = first-episode sample, $\mathrm{NR}=$ not reported, $\mathcal{P}=$ heterogeneity, $\mathrm{Cl}=$ confidence interval 
Supplement Figure 2c. Meta-analysis on positive symptoms in psychotic depression (PD) and schizophrenia (SZ).

\section{Positive psychosis symptoms in PD vs SZ}

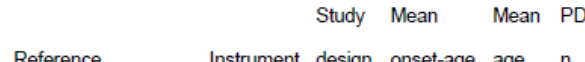

Hedges' g $(95 \% \mathrm{Cl}) \quad$ Weight \%

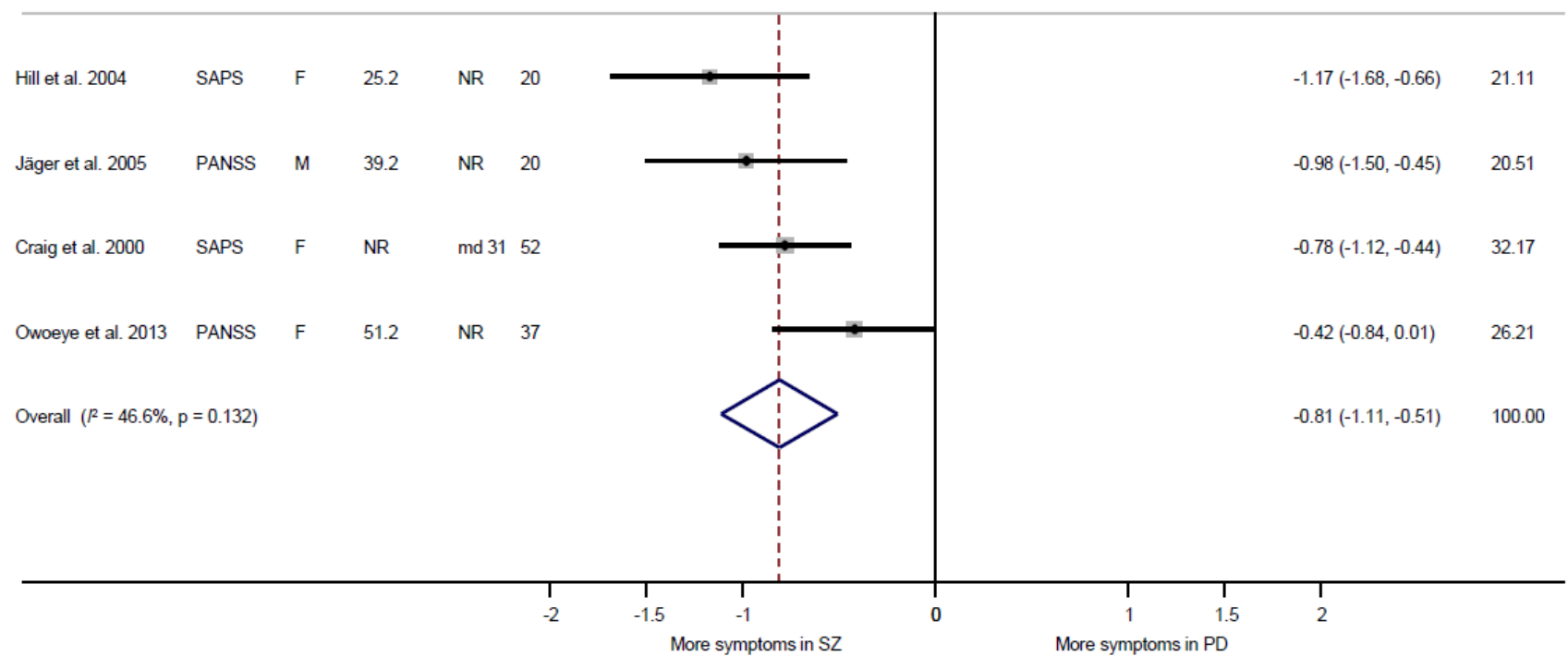

Abbreviations: $\mathrm{PD}=$ psychotic depression, $\mathrm{SZ}=$ schizophrenia, SAPS $=$ Scale for Assessment of Positive Symptoms, PANSS $=$ Positive and Negative Syndrome Scale, F = firstepisode sample, $\mathrm{M}=$ mixed sample, $\mathrm{NR}=$ not reported, $R=$ heterogeneity, $\mathrm{Cl}=$ confidence interval. 
Supplement Figure 2d. Meta-analysis on negative symptoms in psychotic depression (PD) and schizophrenia (SZ).

Negative psychosis symptoms in PD vs SZ

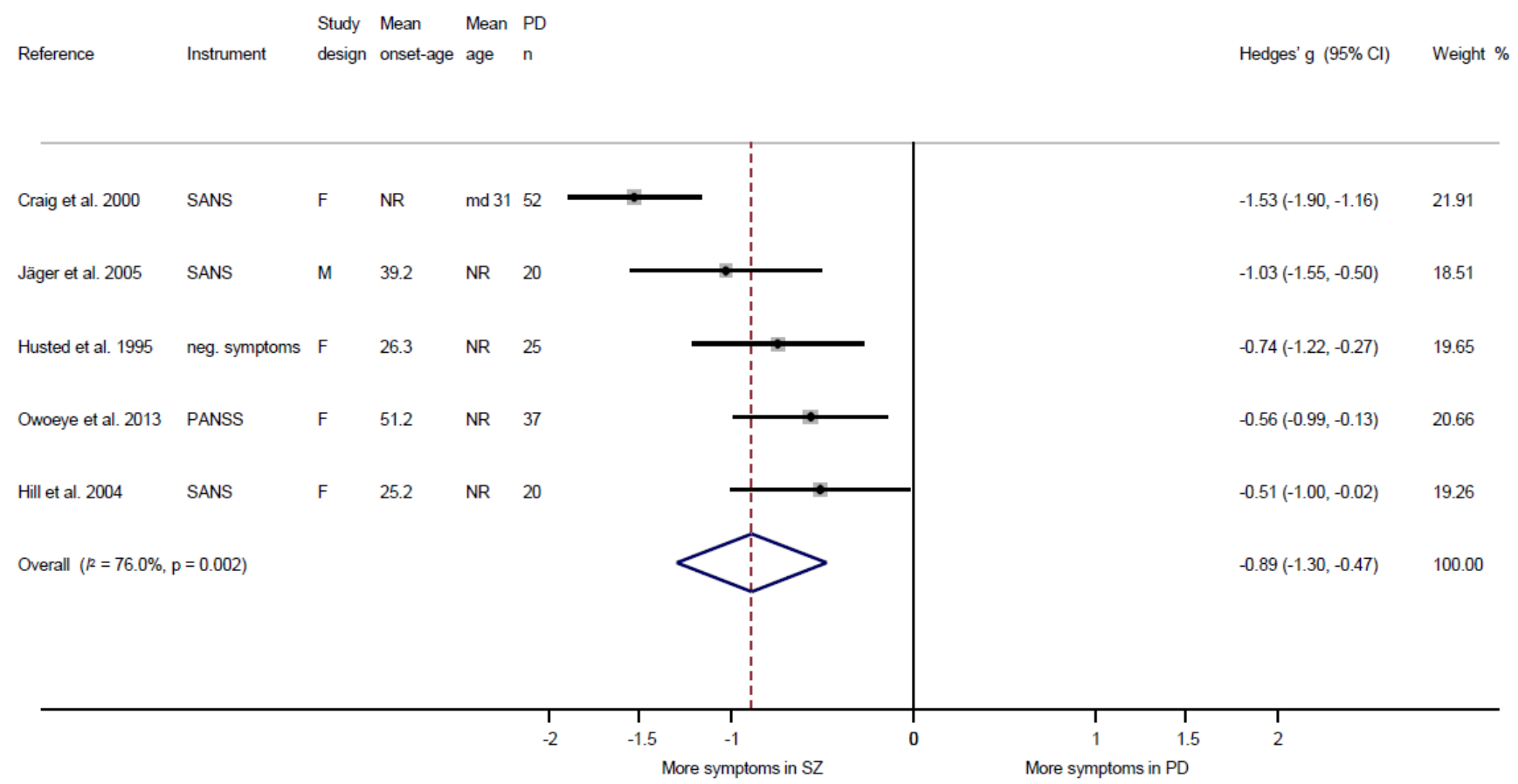

Abbreviations: $\mathrm{PD}=$ psychotic depression, $\mathrm{SZ}=$ schizophrenia, SANS = Scale for Assessment of Negative Symptoms, PANSS = Positive and Negative Syndrome Scale, F = firstepisode sample, $\mathrm{M}=$ mixed sample, $\mathrm{NR}=$ not reported, $P^{2}=$ heterogeneity, $\mathrm{Cl}=$ confidence interval 
Supplement Figure 2e. Meta-analysis on global outcome in psychotic depression (PD) and schizophrenia (SZ).

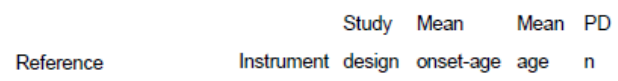

Hedges' g $(95 \% \mathrm{Cl}) \quad$ Weight $\%$

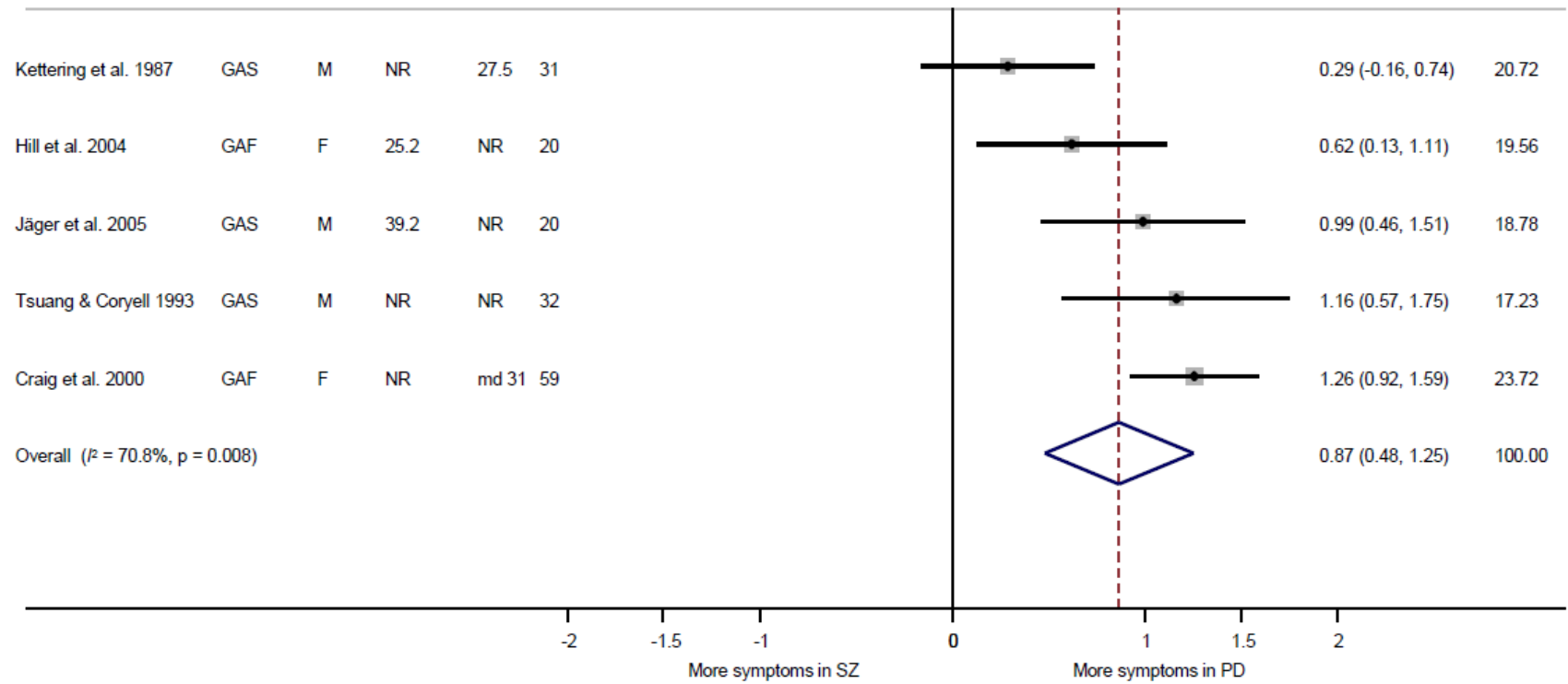

Abbreviations: $\mathrm{PD}=$ psychotic depression, $\mathrm{SZ}=$ schizophrenia, $\mathrm{GAF}=$ The Global Assessment of Functioning Scale, GAS = Global Assessment Scale, $\mathrm{M}=$ mixed sample, $\mathrm{F}=$ first-episode sample, $\mathrm{NR}=$ not reported, $\mathrm{R}=$ heterogeneity, $\mathrm{Cl}=$ confidence interval. 
Supplement Figure 3a. Meta-analysis on symptoms of depression in psychotic depression (PD) and psychotic bipolar disorder (PBD).

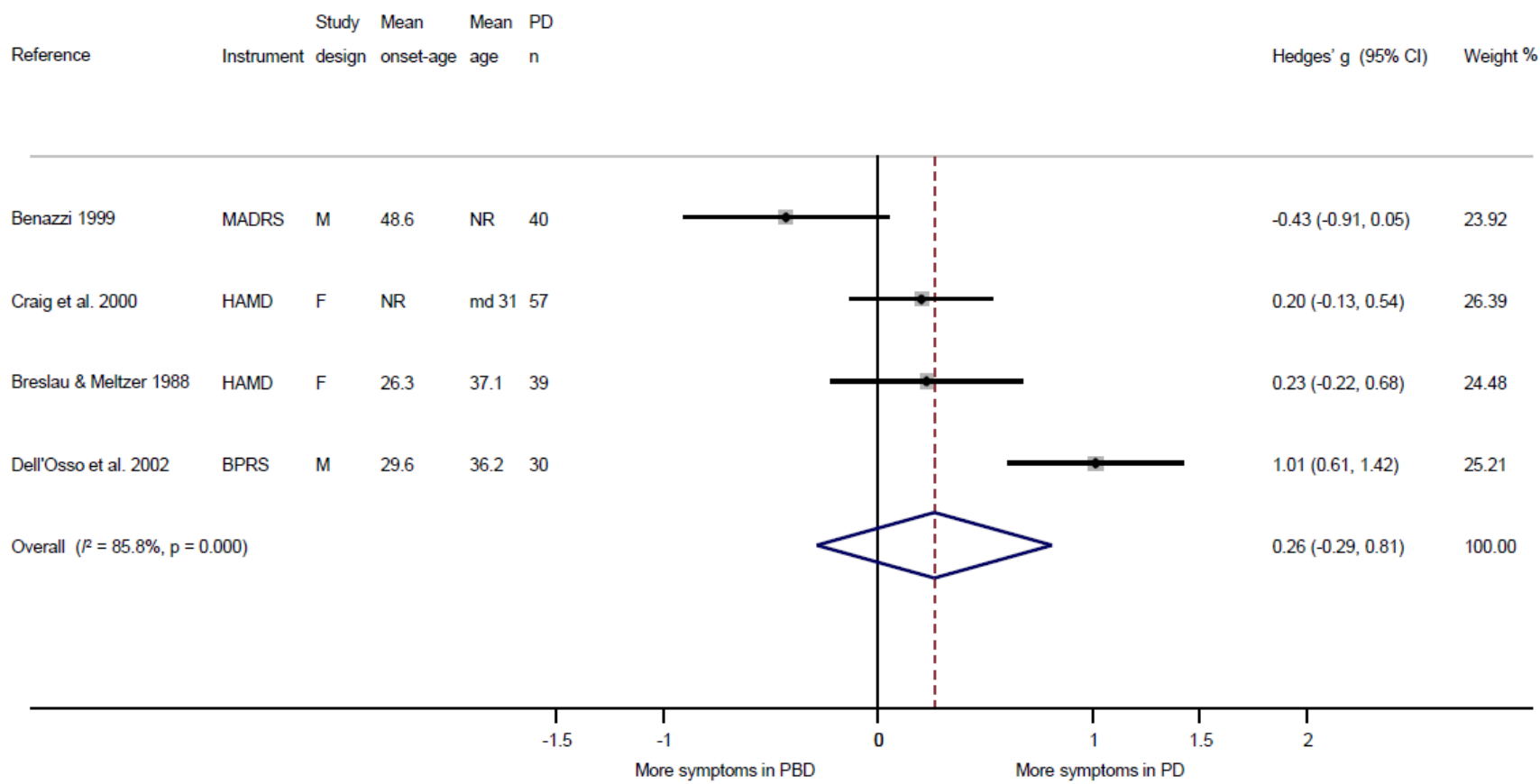

Abbreviations: $\mathrm{PD}=$ psychotic depression, $\mathrm{PBD}=$ psychotic bipolar disorder, HAMD $=$ Hamilton Rating Scale for Depression, BPRS = Brief Psychiatric Rating Scale, MADRS = Montgomery-Asberg Depression Rating Scale, $\mathrm{M}=$ mixed sample, $\mathrm{F}=$ first-episode sample, $\mathrm{NR}=$ not reported, $\mathrm{P}=$ heterogeneity, $\mathrm{Cl}=$ confidence interval . 
Supplement Figure 3b. Meta-analysis on positive symptoms in psychotic depression (PD) and psychotic bipolar disorder (PBD).

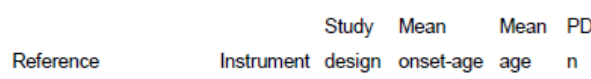

Hedges' $\mathrm{g}(95 \% \mathrm{Cl}) \quad$ Weight \%

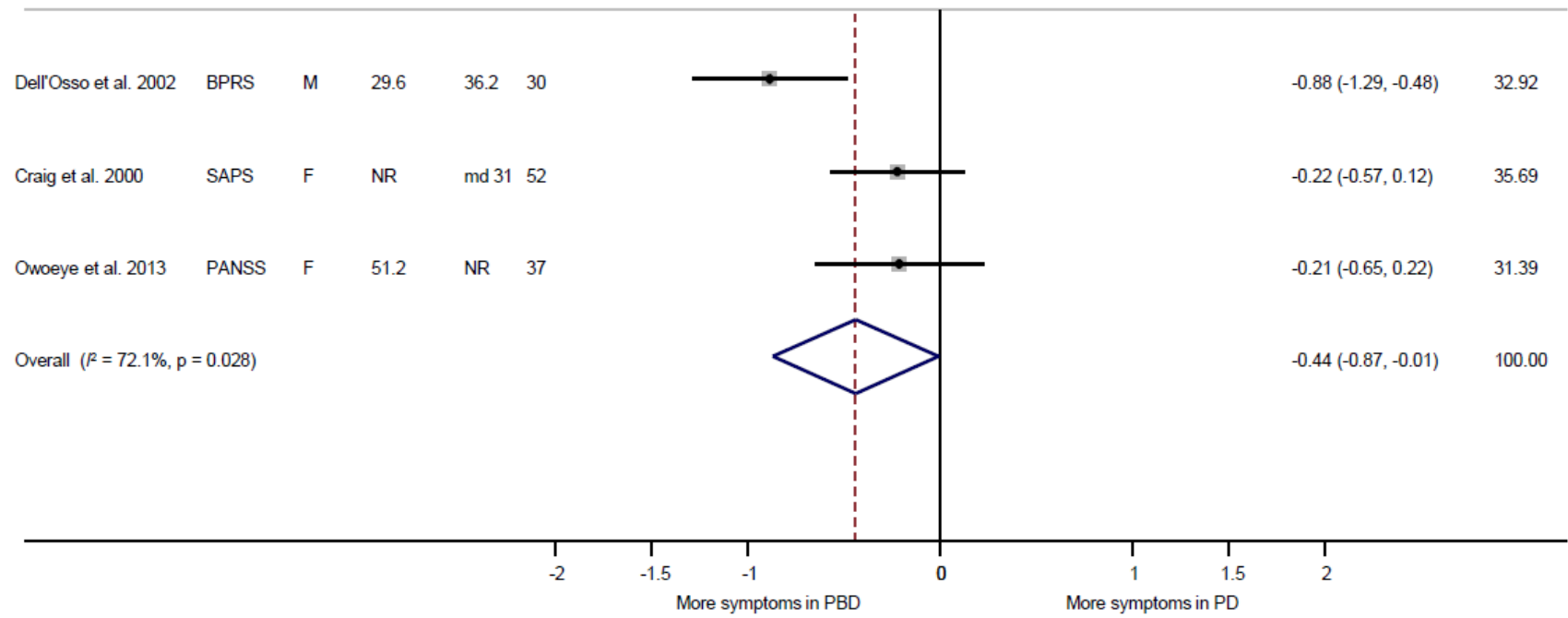

Abbreviations: PD = psychotic depression, PBD= psychotic bipolar disorder, SAPS = Scale for Assessment of Positive Symptoms, BPRS = Brief Psychiatric Rating Scale, PANSS = Positive and Negative Syndrome Scale, $\mathrm{M}=$ mixed sample, $\mathrm{F}=$ first-episode sample, $\mathrm{NR}=$ not reported, $\mathrm{R}=$ heterogeneity, $\mathrm{Cl}=$ confidence interval 
Supplement Figure 3c. Meta-analysis on negative symptoms in psychotic depression (PD) and psychotic bipolar disorder (PBD).

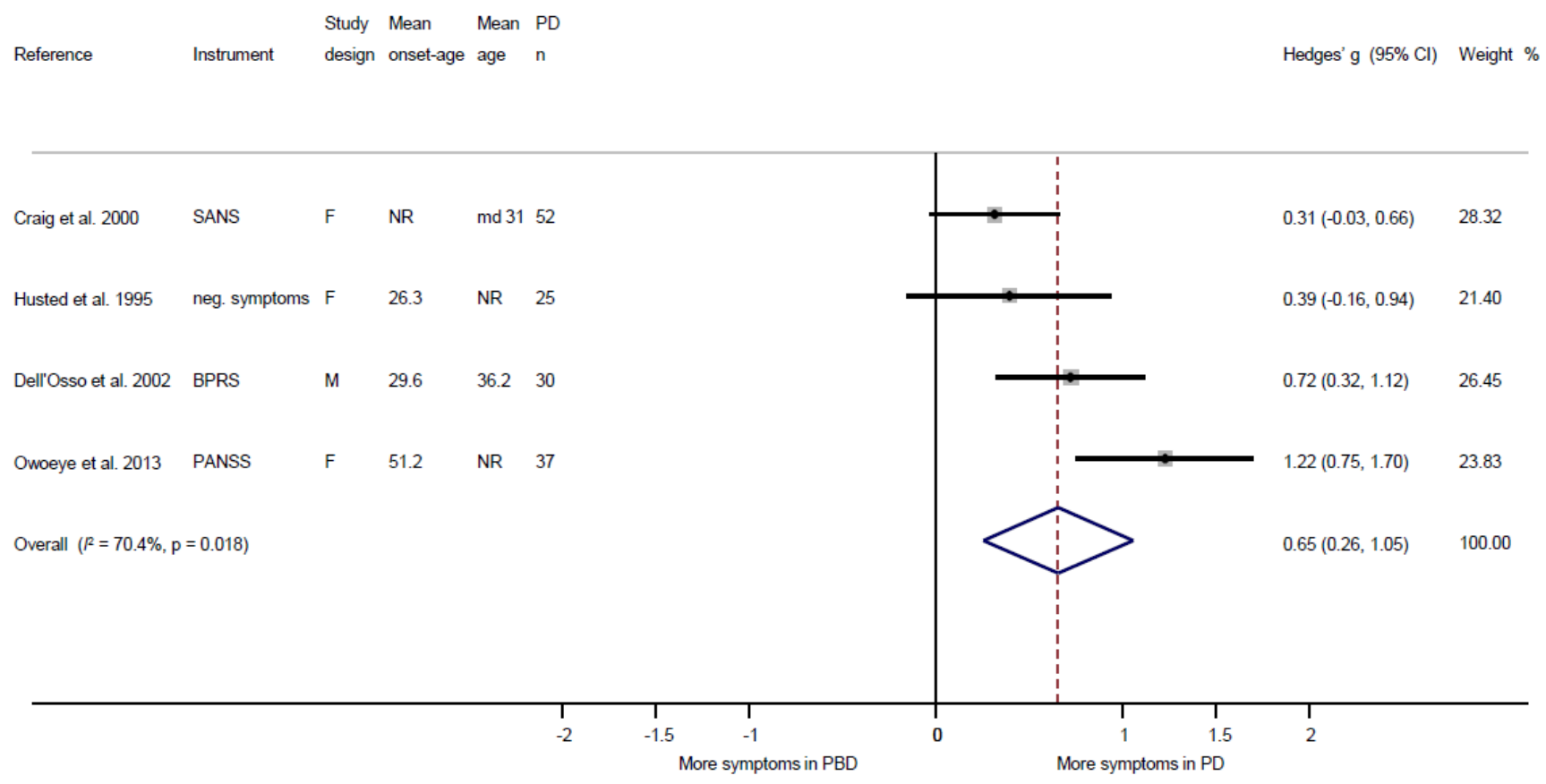

Abbreviations: PD = psychotic depression, PBD = psychotic bipolar disorder, SANS = Scale for Assessment of Negative Symptoms, BPRS = Brief Psychiatric Rating Scale, PANSS = Positive and Negative Syndrome Scale, $\mathrm{F}=$ first-episode sample, $\mathrm{M}=$ mixed sample, $\mathrm{NR}=$ not reported, $\mathrm{R}=$ heterogeneity, $\mathrm{Cl}=$ confidence interval. 
Supplement Figure 3d. Meta-analysis on global outcome in psychotic depression (PD) and psychotic bipolar disorder (PBD).

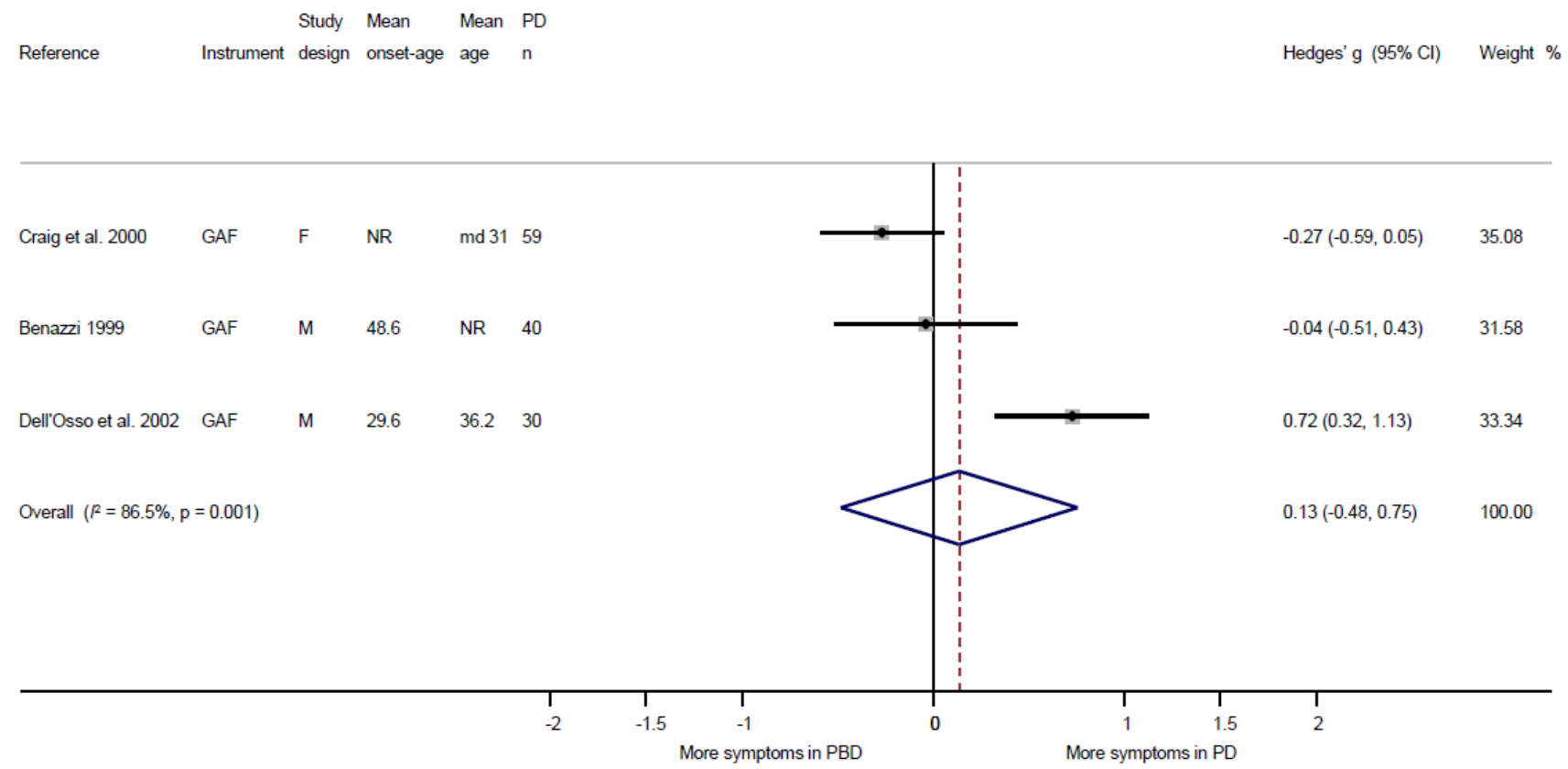

Abbreviations: $\mathrm{PD}=$ psychotic depression, $\mathrm{PBD}=$ psychotic bipolar disorder, $\mathrm{GAF}=$ The Global Assessment of Functioning Scale, $\mathrm{F}=$ first-episode sample, $\mathrm{M}=$ mixed sample, $\mathrm{NR}=$ not reported,$R=$ heterogeneity, $\mathrm{Cl}=$ confidence interval . 
Supplement Figure 4a. Sensitivity analysis: Difference in depression symptoms in PD compared to NPD in strata by sample size.

Symptoms of depression in PD vs NPD

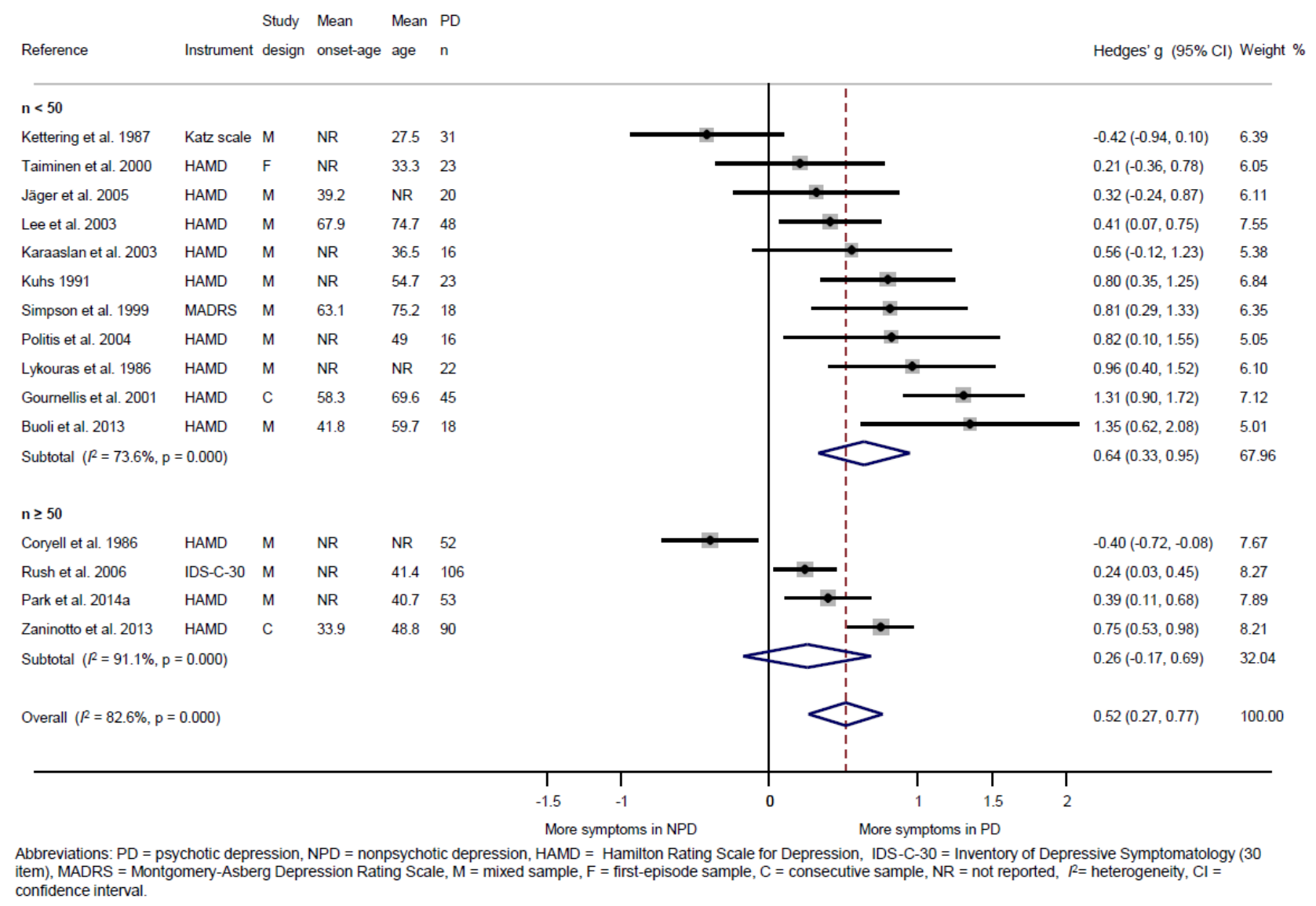


Supplement Figure $\mathbf{4 b}$. Sensitivity analysis: difference in global outcome in PD compared to NPD in strata by sample size.

Global outcome in PD vs NPD

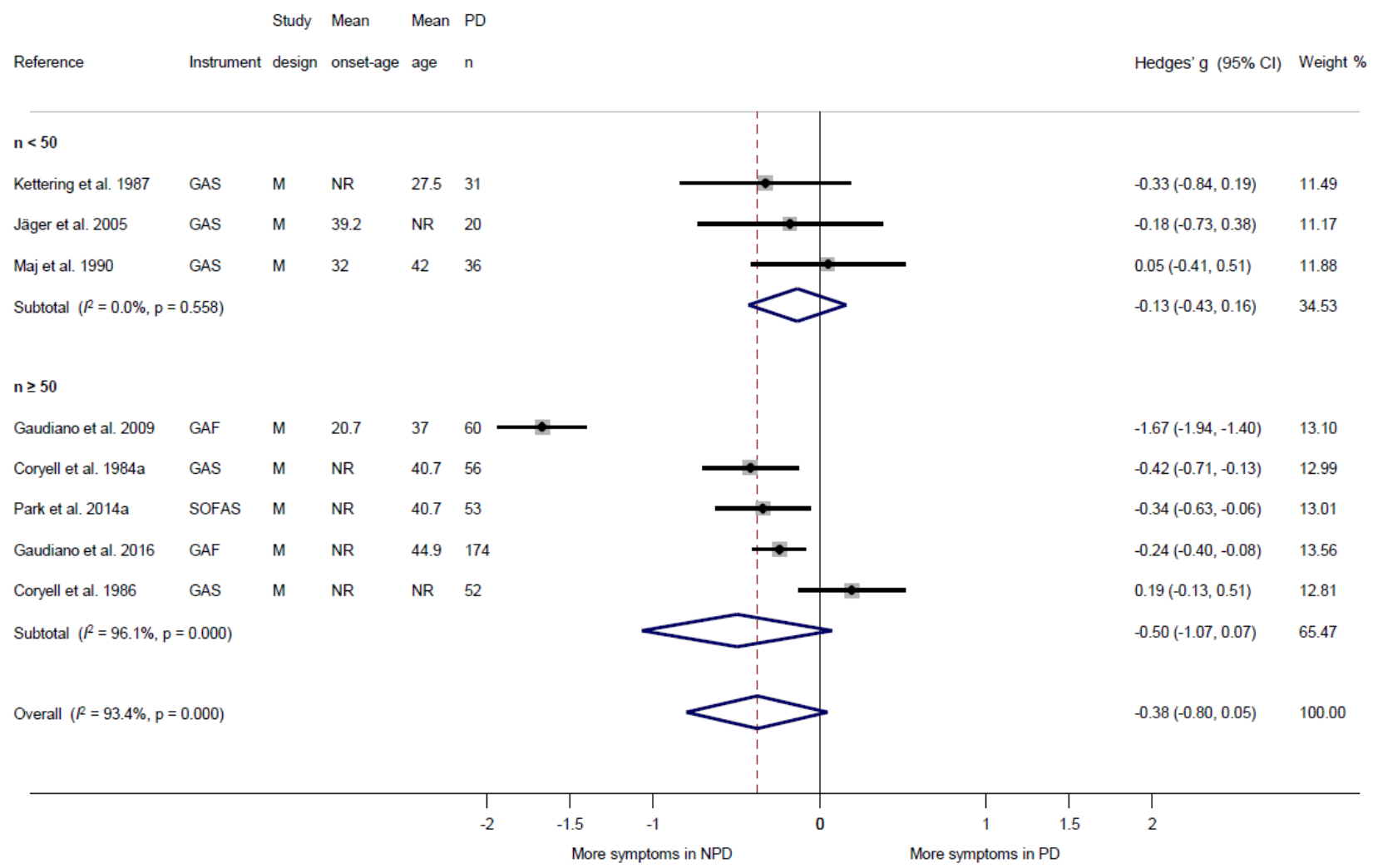

Abbreviations: $\mathrm{PD}=$ psychotic depression, NPD = nonpsychotic depression, GAF = The Global Assessment of Functioning Scale, GAS = Global Assessment Scale, SOFAS = Social and Occupational Functioning Assessment Scale, $\mathrm{M}=$ mixed sample, $\mathrm{NR}=$ not reported, $R=$ heterogeneity, $\mathrm{Cl}=$ confidence interval. 
Supplement Figure 4c. Sensitivity analysis: difference in symptomatic remission in PD compared to NPD in strata by sample size.

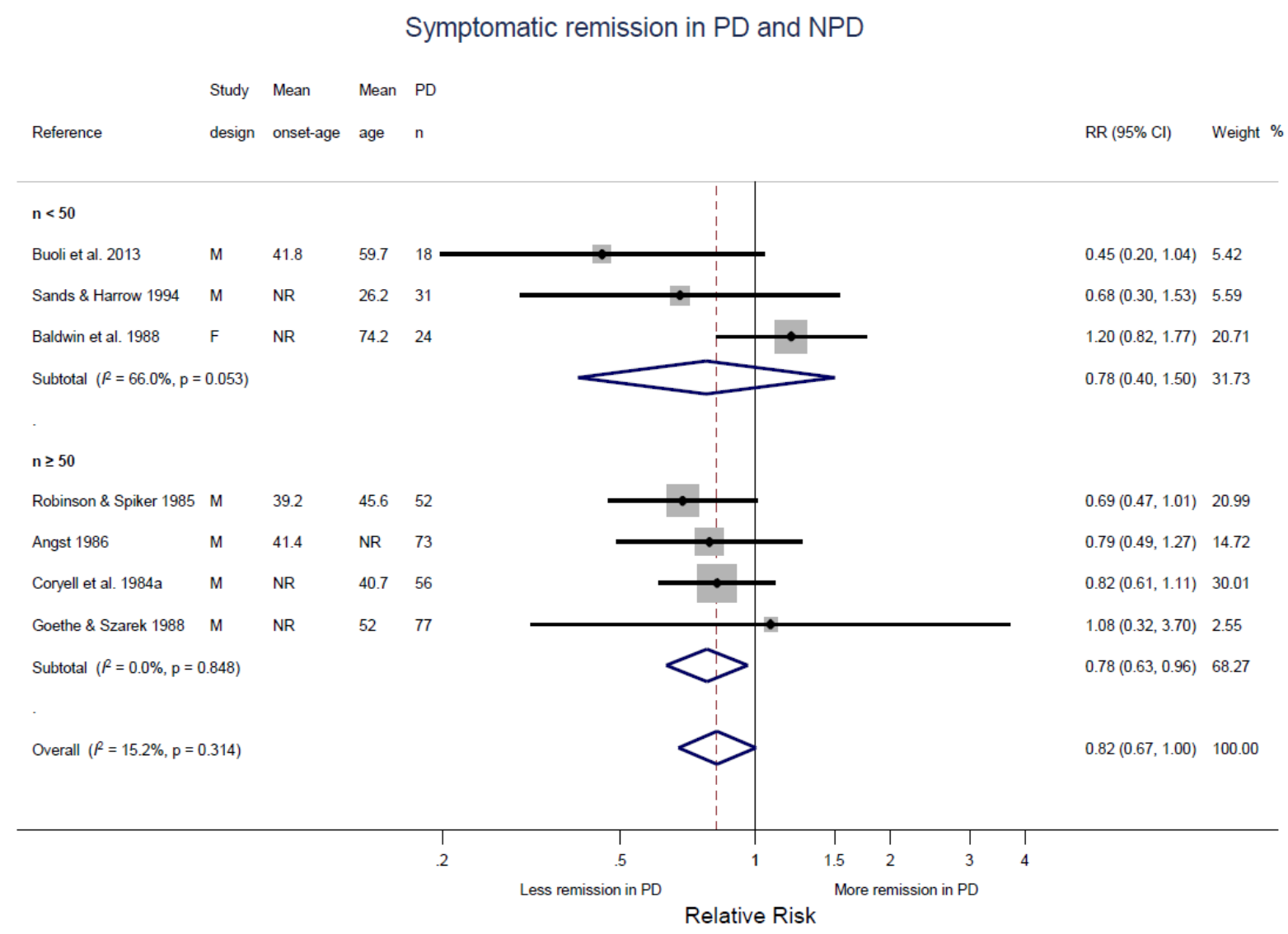

Abbreviations: $\mathrm{PD}=$ psychotic depression, $\mathrm{NPD}=$ nonpsychotic depression, $\mathrm{RR}=$ Relative Risk, $\mathrm{M}=$ mixed sample $\mathrm{F}=$ first-episode sample, $\mathrm{NR}=$ not $\mathrm{reported}, \mathrm{R}=$ heterogeneity, $\mathrm{Cl}=$ confidence interval. 
Supplement Figure 4d. Sensitivity analysis: difference in symptomatic remission in PD compared to NPD in strata by sample size.

Poor global clinical outcome in PD and NPD

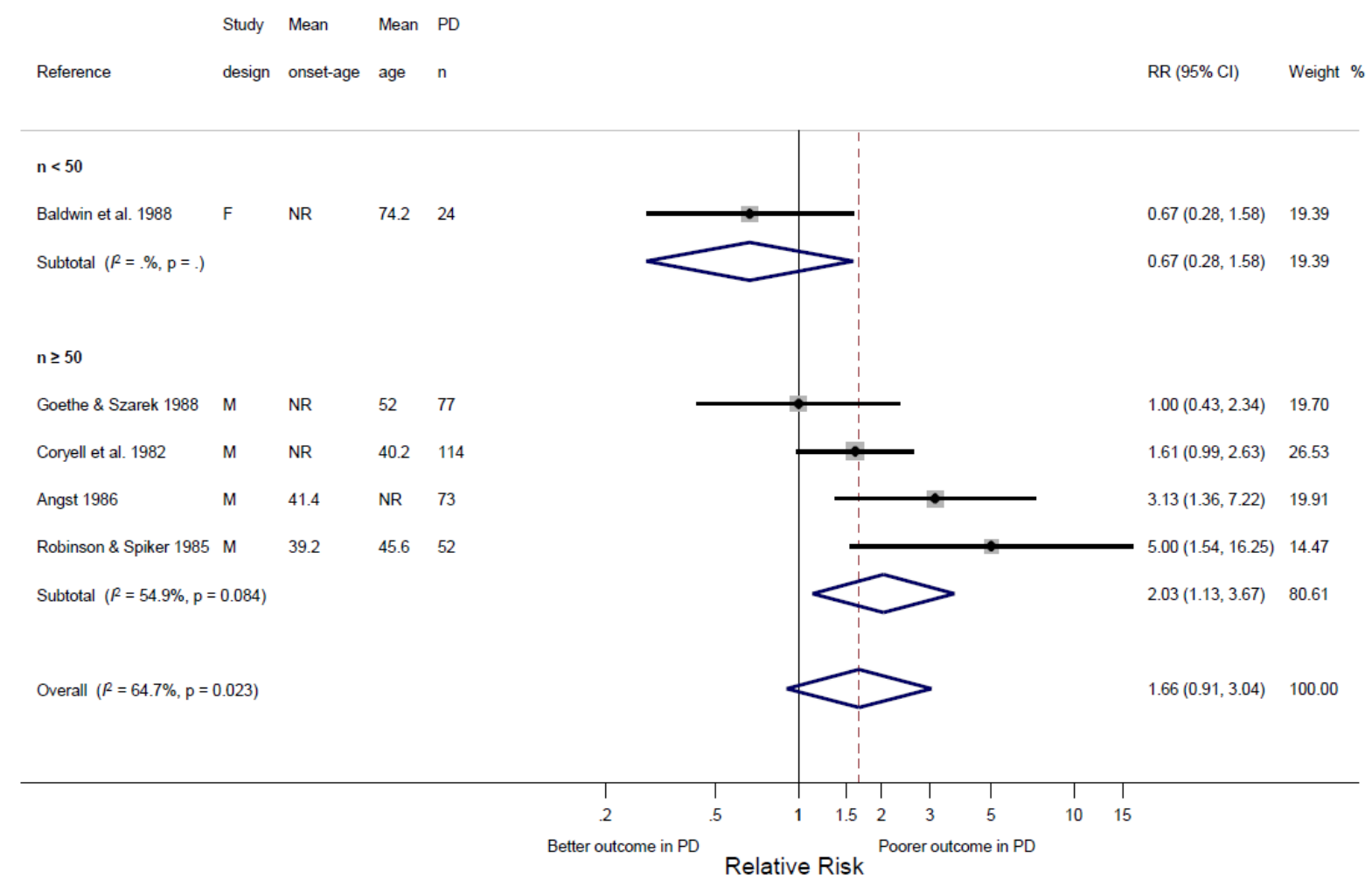

Abbreviations: $\mathrm{PD}=$ psychotic depression, $\mathrm{NPD}=$ nonpsychotic depression, $\mathrm{RR}=$ Relative Risk, $\mathrm{F}=$ first-episode sample, $\mathrm{M}=$ mixed sample, $\mathrm{NR}=$ not reported, $R=$ heterogeneity, $\mathrm{Cl}=$ confidence interval. 


\section{Supplement References}

Angst J (1986). The course of affective disorders. Psychopathology 19 Suppl 2, 47-52.

Baldwin RC (1995). Delusional depression in elderly patients: characteristics and relationship to age at onset. International Journal of Geriatric Psychiatry 10, 981-985.

Baldwin RC (1988). Delusional and non-delusional depression in late life. Evidence for distinct subtypes. British Journal of Psychiatry 152, 39-44.

Baldwin P, Browne D, Scully PJ, Quinn JF, Morgan MG, Kinsella A, Owens JM, Russell V, O'Callaghan E, Waddington JL (2005). Epidemiology of first-episode psychosis: illustrating the challenges across diagnostic boundaries through the Cavan-Monaghan study at 8 years. Schizophrenia Bulletin 31, 624-638.

Beiser M, Erickson D, Fleming JA, lacono WG (1993). Establishing the onset of psychotic illness. The American Journal of Psychiatry 150, 1349-1354.

Benazzi F (1999). Bipolar versus unipolar psychotic outpatient depression. Journal of Affective Disorders 55, 63-66.

Breslau N, Meltzer HY (1988). Validity of subtyping psychotic depression: examination of phenomenology and demographic characteristics. The American Journal of Psychiatry 145, 3540.

Brockington IF, Helzer JE, Hillier VF, Francis AF (1982). Definitions of depression: concordance and prediction of outcome. American Journal of Psychiatry 139, 1022-1027.

Buoli M, Caldiroli A, Altamura AC (2013). Psychotic versus non-psychotic major depressive disorder: a comparative naturalistic study. Asian Journal of Psychiatry 6, 333-337.

Copeland JR (1983). Psychotic and neurotic depression: discriminant function analysis and five-year outcome. Psychological Medicine 13, 373-383.

Coryell W, Endicott J, Keller M (1987). The importance of psychotic features to major depression: course and outcome during a 2-year follow-up. Acta Psychiatrica Scandinavica 75, 78-85.

Coryell W, Endicott J, Keller M, Andreasen NC (1985). Phenomenology and family history in DSMIII psychotic depression. Journal of Affective Disorders 9, 13-18.

Coryell W, Keller M, Lavori P, Endicott J (1990). Affective syndromes, psychotic features, and prognosis. I. Depression. Archives of General Psychiatry 47, 651-657.

Coryell W, Lavori P, Endicott J, Keller M, VanEerdewegh M (1984a). Outcome in schizoaffective, psychotic, and nonpsychotic depression. Course during a six- to 24-month follow-up. Archives of General Psychiatry 41, 787-791.

Coryell W, Tsuang MT (1982). Primary unipolar depression and the prognostic importance of delusions. Archives of General Psychiatry 39, 1181-1184. 
Coryell W, Tsuang MT (1985). Major depression with mood-congruent or mood-incongruent psychotic features: outcome after 40 years. The American Journal of Psychiatry 142, 479-482.

Coryell W, Tsuang MT, McDaniel J (1982). Psychotic features in major depression. Is mood congruence important? Journal of Affective Disorders 4, 227-236.

Coryell W, Pfohl B, Zimmerman M (1984b). The clinical and neuroendocrine features of psychotic depression. Journal of Nervous and Mental Disease 172, 521-528.

Coryell W, Zimmerman M (1988). The Heritability of schizophrenia and schizoaffective disorder: a family study. Archives of General Psychiatry 45, 323-327.

Coryell W, Zimmerman M, Pfohl B (1986). Outcome at discharge and six months in major depression the significance of psychotic features. Journal of Nervous and Mental Disease 174, 92-96.

Craig T, Bromet EJ (2004). Parents with psychosis. Annals of Clinical Psychiatry 16, 35-39.

Craig TJ, Bromet EJ, Fennig S, Tanenberg-Karant M, Lavelle J \& Galambos N (2000). Is there an association between duration of untreated psychosis and 24-month clinical outcome in a firstadmission series? American Journal of Psychiatry 157, 60-66.

Craig TJ, Bromet EJ, Jandorf L, Fennig S, Tanenberg-Karant M, Ram R, Rosen B (1997). Diagnosis, treatment, and six-month outcome status in first-admission psychosis. Annals of Clinical Psychiatry 9, 89-97.

Crebbin K, Mitford E, Paxton R, Turkington D (2008). First-episode psychosis: an epidemiological survey comparing psychotic depression with schizophrenia. Journal of Affective Disorders 105, 117-124.

Čulav-Sumić J, Jukić V (2010). Minor physical anomalies in women with recurrent unipolar depression. Psychiatry Research 176, $22-25$.

Dell'Osso L, Pini S, Cassano GB, Mastrocinque C, Seckinger RA, Saettoni M, Papasogli A, Yale SA, Amador XF (2002). Insight into illness in patients with mania, mixed mania, bipolar depression and major depression with psychotic features. Bipolar Disorders 4, 315-322.

Draper B, Anstey K (1996). Psychosocial stressors, physical illness and the spectrum of depression in elderly inpatients. The Australian and New Zealand Journal of Psychiatry 30, 567-572.

Draper B, Low LF (2009). Patterns of hospitalisation for depressive and anxiety disorders across the lifespan in Australia. Journal of Affective Disorders 113, 195-200.

Endicott J, Nee J, Andreasen N, Clayton P, Keller M, Coryell W (1985). Bipolar II. Combine or keep separate? Journal of Affective Disorders 8, 17-28.

Farquhar F, Le Noury J, Tschinkel S, Harris M, Kurien R, Healy D (2007). The incidence and prevalence of manic-melancholic syndromes in North West Wales: 1875-2005. Acta Psychiatrica Scandinavica. Supplementum 433, 37-43.

Fennig S, Bromet EJ, Galambos N, Putnam K (1996). Diagnosis and six-month stability of negative symptoms in psychotic disorders. European Archives of Psychiatry and Clinical Neuroscience 
246, 63-70.

Fennig S, Bromet EJ, Karant MT, Ram R, Jandorf L (1996). Mood-congruent versus moodincongruent psychotic symptoms in first-admission patients with affective disorder. Journal of Affective Disorders 37, 23-29.

Filatova S, Marttila R, Koivumaa-Honkanen H, Nordström T, Veijola J, Mäki P, Khandaker GM, Isohanni M, Jääskeläinen E, Moilanen K, Miettunen J (2016). A comparison of the cumulative incidence and early risk factors for psychotic disorder in young adults in the Northern Finland Birth Cohorts 1966 and 1986. Epidemiology and Psychiatric Sciences [epub ahead of print].

Forty L, Jones L, Jones I, Cooper C, Russell E, Farmer A, McGuffin P, Craddock N (2009). Is depression severity the sole cause of psychotic symptoms during an episode of unipolar major depression? A study both between and within subjects. Journal of Affective Disorders 114, 103109.

Frances A, Brown RP, Kocsis JH \& Mann JJ (1981). Psychotic depression: a separate entity? The American Journal of Psychiatry 138, 831-833.

Frangos E, Athanassenas G, Tsitourides S, Psilolignos P, Katsanou N (1983). Psychotic depressive disorder. A separate entity? Journal of Affective Disorders 5, 259-265.

Gaudiano BA, Dalrymple KL, Zimmerman M (2009). Prevalence and clinical characteristics of psychotic versus nonpsychotic major depression in a general psychiatric outpatient clinic. Depression and Anxiety 26, 54-64.

Gaudiano BA, Weinstock LM, Epstein-Lubow G, Uebelacker LA, Miller IW (2016). Clinical characteristics and medication use patterns among hospitalized patients admitted with psychotic vs nonpsychotic major depressive disorder. Annals of Clinical Psychiatry 28, 56-63.

Gaudiano BA, Young D, Chelminski I, Zimmerman M (2008). Depressive symptom profiles and severity patterns in outpatients with psychotic vs nonpsychotic major depression. Comparative Psychiatry 49, 421-429.

Gaudiano BA, Zimmerman M (2010). The relationship between childhood trauma history and the psychotic subtype of major depression. Acta Psychiatrica Scandinavica 121, 462-470.

Goethe JW, Szarek BL (1988). Do DSM-III criteria for major depression define distinct subtypes? The Psychiatric hospital 19, 175-178.

Goethe JW, Szarek BL, Cook WL (1988). A comparison of adequately vs. inadequately treated depressed patients. Journal of Nervous and Mental Disease 176, 465-470.

Goldberg JF, Harrow M (2005). Subjective life satisfaction and objective functional outcome in bipolar and unipolar mood disorders: a longitudinal analysis. Journal of Affective Disorders 89, 79-89.

Goldberg JF, Harrow M (2004). Consistency of remission and outcome in bipolar and unipolar mood disorders: a 10-year prospective follow-up. Journal of Affective Disorders 81, 123-131.

Goldstein RB, Horwath E, Wickramaratne PJ, Wolk SI, Warner V, Weissman MM (1998). Familial aggregation of delusional depression: re-examination in a recent family study. Depression and 
Anxiety 8, 160-165.

Gournellis R, Lykouras L, Fortos A, Oulis P, Roumbos V, Christodoulou GN (2001). Psychotic (delusional) major depression in late life: a clinical study. International Journal of Geriatric Psychiatry 16, 1085-1091.

Heslin M, Desai R, Lappin JM, Donoghue K, Lomas B, Reininghaus U, Onyejiaka A, Croudace T, Jones PB, Murray RM, Fearon P, Doody GA, Dazzan P, Fisher HL, Demjaha A, Craig T, Morgan C (2016). Biological and psychosocial risk factors for psychotic major depression. Social Psychiatry and Psychiatric Epidemiology 51, 233-245

Hill SK, Keshavan MS, Thase ME, Sweeney JA (2004). Neuropsychological dysfunction in antipsychotic-naive first-episode unipolar psychotic depression. The American Journal of Psychiatry 161, 996-1003.

Hori M, Shiraishi H, Koizumi J (1993). Delusional depression and suicide. The Japanese Journal of Psychiatry and Neurology 47, 811-817.

Husted JA, Beiser M, lacono WG (1995). Negative symptoms in the course of first-episode affective psychosis. Psychiatry Research 56, 145-154.

Ihezue UH (1985). Observations and comments on the psychosocial determinants of depressive illness among Nigerian adults. Journal of the National Medical Association 77, 729-733.

Jäger M, Bottlender R, Strauss A, Möller HJ (2005). Fifteen-year follow-up of Diagnostic and Statistical Manual of Mental Disorders, Fourth Edition depressive disorders: the prognostic significance of psychotic features. Comprehensive Psychiatry 46, 322-327.

Jarbin H, Ott Y, Von Knorring AL (2003). Adult outcome of social function in adolescent-onset schizophrenia and affective psychosis. Journal of the American Academy of Child and Adolescent Psychiatry 42, 176-183.

Johnson J, Horwath E, Weissman MM (1991). The validity of major depression with psychotic features based on a community study. Archives of General Psychiatry 48, 1075-1081.

Karaaslan F, Gonul AS, Oguz A, Erdinc E, Esel E (2003). P300 changes in major depressive disorders with and without psychotic features. Journal of Affective Disorders 73, 283-287.

Kessing LV (2006). Gender differences in subtypes of late-onset depression and mania. International Psychogeriatrics 18, 727-738.

Kessing LV (2005). Gender differences in patients presenting with a single depressive episode according to ICD-10. Social Psychiatry and Psychiatric Epidemiology 40, 197-201.

Kettering RL, Harrow M, Grossman L, Meltzer HY (1987). The prognostic relevance of delusions in depression: a follow-up study. American Journal of Psychiatry 144, 1154-1160.

Kivelä SL, Pahkala K (1989). Delusional depression in the elderly: a community study. Zeitschrift fur Gerontologie 22, 236-241.

Kuhs H (1991). Depressive delusion. Psychopathology 24, 106-114. 
Lee TW, Tsai SJ, Yang CH, Hwang JP (2003). Clinical and phenomenological comparisons of delusional and non-delusional major depression in the Chinese elderly. International Journal of Geriatric Psychiatry 18, 486-490.

Leyton M, Corin E, Martial J, Meaney M (1995). Psychotic symptoms and vulnerability to recurrent major depression. Journal of Affective Disorders 33, 107-115.

Lykouras E, Malliaras D, Christodoulou GN, Papakostas Y, Voulgari A, Tzonou A, Stefanis C (1986). Delusional depression: phenomenology and response to treatment. A prospective study. Acta Psychiatrica Scandinavica 73, 324-329.

Maj M, Pirozzi R, Di Caprio EL (1990). Major depression with mood-congruent psychotic features: a distinct diagnostic entity or a more severe subtype of depression? Acta Psychiatrica Scandinavica 82, 439-444.

Maj M, Pirozzi R, Magliano L, Fiorillo A, Bartoli L (2007). Phenomenology and prognostic significance of delusions in major depressive disorder: a 10-year prospective follow-up study. The Journal of Clinical Psychiatry 68, 1411-1417.

Maj M, Starace F, Pirozzi R (1991). A family study of DSM-III-R schizoaffective disorder, depressive type, compared with schizophrenia and psychotic and nonpsychotic major depression. The American Journal of Psychiatry 148, 612-616.

Meyers BS, Alexopoulos GS, Kakuma T, Tirumalasetti F, Gabriele M, Alpert S, Bowden C, Meltzer HY (1999). Decreased dopamine beta-hydroxylase activity in unipolar geriatric delusional depression. Biological psychiatry 45, 448-452.

Meyers BS, Greenberg R (1986). Late-life delusional depression. Journal of Affective Disorders 11, 133-137.

Nakamura K, Iga J, Matsumoto N, Ohmori T (2015). Risk of bipolar disorder and psychotic features in patients initially hospitalised with severe depression. Acta Neuropsychiatrica 27, 113-118.

Ohaeri JU, Otote DI (2002). Family history, life events and the factorial structure of depression in a Nigerian sample of inpatients. Psychopathology 35, 210-219.

Ohayon MM, Schatzberg AF (2002). Prevalence of depressive episodes with psychotic features in the general population. The American Journal of Psychiatry 159, 1855-1861.

Okulate GT, Oladapo HT, Osibogun A (2001). Comparison of three subtypes of depression. The Nigerian Postgraduate Medical Journal 8, 41-45.

Opjordsmoen S (1991). Unipolar delusional depression. Outcome in reactive versus endogenous types. Psychopathology 24, 260-269.

Østergaard SD, Petrides G, Dinesen PT, Skadhede S, Bech P, Munk-Jørgensen P, Nielsen J (2013a). The association between physical morbidity and subtypes of severe depression. Psychotherapy and Psychosomatics 82, 45-52.

Østergaard SD, Waltoft BL, Mortensen PB, Mors O (2013b). Environmental and familial risk factors for psychotic and non-psychotic severe depression. Journal of Affective Disorders 147, 232-240. 
Owoeye O, Kingston T, Scully PJ, Baldwin P, Browne D, Kinsella A, Russell V, O'Callaghan E, Waddington JL (2013). Epidemiological and clinical characterization following a first psychotic episode in major depressive disorder: comparisons with schizophrenia and bipolar I disorder in the Cavan-Monaghan First Episode Psychosis Study (CAMFEPS). Schizophrenia Bulletin 39, 756-765.

Park SC, Choi J, Kim JM, Jun TY, Lee MS, Kim JB, Yim HW, Park YC (2014a). Is the Psychotic Depression Assessment Scale a useful diagnostic tool? The CRESCEND study. Journal of Affective Disorders 166, 79-85.

Park SC, Lee HY, Sakong JK, Jun TY, Lee MS, Kim JM, Kim JB, Yim HW, Park YC (2014b). Distinctive clinical correlates of psychotic major depression: The CRESCEND Study. Psychiatry Investigation 11, 281-289.

Parker G, Hadzi-Pavlovic D, Hickie I, Mitchell P, Wilhelm K, Brodaty H, Boyce P, Eyers K, Pedic F (1991). Psychotic depression: a review and clinical experience. The Australian and New Zealand Journal of Psychiatry 25, 169-180.

Pederson AM, Barry DJ, Babigian HM (1972). Epidemiological considerations of psychotic depression. Archives of General Psychiatry 27, 193-197.

Perälä J, Suvisaari J, Saarni SI, Kuoppasalmi K, Isometsä E, Pirkola S, Partonen T, TuulioHenriksson A, Hintikka J, Kieseppä T, Härkänen T, Koskinen S, Lönnqvist J (2007). Lifetime prevalence of psychotic and bipolar I disorders in a general population. Archives of General Psychiatry 64, 19-28.

Politis A, Lykouras L, Mourtzouchou P, Christodoulou GN (2004). Attentional disturbances in patients with unipolar psychotic depression: a selective and sustained attention study. Comprehensive Psychiatry 45, 452-459.

Reay R, Mitford E, McCabe K, Paxton R, Turkington D (2010). Incidence and diagnostic diversity in first-episode psychosis. Acta Psychiatrica Scandinavica 121, 315-319.

Robinson DG, Spiker DG (1985). Delusional depression. A one year follow-up. Journal of Affective Disorders 9, 79-83.

Rush AJ, Carmody TJ, Ibrahim HM, Trivedi MH, Biggs MM, Shores-Wilson K, Crismon ML, Toprac MG, Kashner TM (2006). Comparison of self-report and clinician ratings on two inventories of depressive symptomatology. Psychiatric Services 57, 829-837.

Rybakowski JK, Suwalska A, Lojko D, Rymaszewska J, Kiejna A (2007). Types of depression more frequent in bipolar than in unipolar affective illness: results of the Polish DEP-BI study. Psychopathology 40, 153-158.

Sands JR, Harrow M (1994). Psychotic unipolar depression at follow-up: factors related to psychosis in the affective disorders. The American Journal of Psychiatry 151, 995-1000.

Sands JR, Harrow M (1995). Vulnerability to psychosis in unipolar major depression: is premorbid functioning involved? The American Journal of Psychiatry 152, 1009-1015.

Simpson S, Baldwin RC, Jackson A, Burns A (1999). The differentiation of DSM-III-R psychotic depression in later life from nonpsychotic depression: comparisons of brain changes measured by 
multispectral analysis of magnetic resonance brain images, neuropsychological findings, and clinical features. Biological Psychiatry 45, 193-204.

Spicer CC, Hare EH, Slater E (1973). Neurotic and psychotic forms of depressive illness. Evidence from age incidence in a national sample. British Journal of Psychiatry 123, 535-541.

Taiminen T, Jääskeläinen S, Ilonen T, Meyer H, Karlsson H, Lauerma H, Leinonen KM, Wallenius E, Kaljonen A, Salokangas RK (2000). Habituation of the blink reflex in first-episode schizophrenia, psychotic depression and non-psychotic depression. Schizophrenia Research 44, 69-79.

Thakur M, Hays J, Krishnan KR (1999). Clinical, demographic and social characteristics of psychotic depression. Psychiatry Research 86, 99-106.

Tohen M, Strakowski SM, Zarate C,Jr, Hennen J, Stoll AL, Suppes T, Faedda GL, Cohen BM, Gebre-Medhin P, Baldessarini RJ (2000). The McLean-Harvard first-episode project: 6-month symptomatic and functional outcome in affective and nonaffective psychosis. Biological Psychiatry 48, 467-476.

Tohen M, Stoll AL, Strakowski SM, Faedda GL, Mayer PV, Goodwin DC, Kolbrener ML, Madigan AM (1992). The McLean First-Episode Psychosis Project: six-month recovery and recurrence outcome. Schizophrenia Bulletin 18, 273-282.

Tsuang D, Coryell W (1993). An 8-year follow-up of patients with DSM-III-R psychotic depression, schizoaffective disorder, and schizophrenia. The American Journal of Psychiatry 150, 1182-1188.

Zaninotto L, Souery D, Calati R, Sentissi O, Kasper S, Akimova E, Zohar J, Montgomery S, Mendlewicz J, Serretti A (2013). Treatment resistance in severe unipolar depression: no association with psychotic or melancholic features. Annals of Clinical Psychiatry 25, 97-106. 